\title{
Therapeutic Modulation of Autophagy in Leukaemia and Lymphoma
}

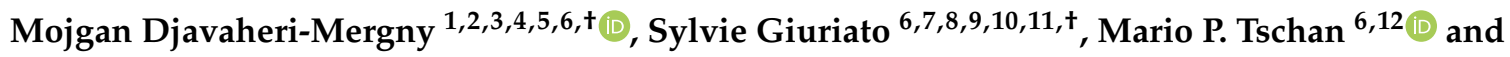 \\ Magali Humbert ${ }^{12, *(D)}$ \\ 1 INSERM U1218, Université de Bordeaux, 33076 Bordeaux, France; mojgan.mergny@inserm.fr \\ INSERM U1138, 75006 Paris, France \\ Université Paris Descartes, Sorbonne Paris Cité, 75006 Paris, France \\ Université Pierre et Marie Curie, Sorbonne Université, 75006 Paris, France \\ Cell Biology and Metabolomics Platforms, Gustave Roussy Cancer Campus, 94800 Villejuif, France \\ TRANSAUTOPHAGY: European Network for Multidisciplinary Research and Translation of Autophagy \\ Knowledge, COST Action CA15138; sylvie.giuriato@inserm.fr (S.G.); \\ mario.tschan@pathology.unibe.ch (M.P.T.) \\ 7 INSERM, UMR1037 CRCT, F-31000 Toulouse, France \\ 8 Université Toulouse III-Paul Sabatier, UMR1037 CRCT, F-31000 Toulouse, France \\ 9 CNRS, ERL5294 CRCT, F-31000 Toulouse, France \\ 10 Department of Pathology, Boston Children's Hospital and Harvard Medical School, Boston, MA 02115, USA \\ 11 European Research Initiative on ALK-related malignancies (ERIA), F-31000 Toulouse, France \\ 12 Institute of Pathology, Division of Experimental Pathology, University of Bern, Murtenstrasse 31, \\ CH-3008 Bern, Switzerland \\ * Correspondence: magali.humbert@pathology.unibe.ch; Tel.: +41-31-632-8780 \\ + These two authors contributed equally.
}

Received: 31 December 2018; Accepted: 28 January 2019; Published: 30 January 2019

check for updates

\begin{abstract}
Haematopoiesis is a tightly orchestrated process where a pool of hematopoietic stem and progenitor cells (HSPCs) with high self-renewal potential can give rise to both lymphoid and myeloid lineages. The HSPCs pool is reduced with ageing resulting in few HSPC clones maintaining haematopoiesis thereby reducing blood cell diversity, a phenomenon called clonal haematopoiesis. Clonal expansion of HSPCs carrying specific genetic mutations leads to increased risk for haematological malignancies. Therefore, it comes as no surprise that hematopoietic tumours develop in higher frequency in elderly people. Unfortunately, elderly patients with leukaemia or lymphoma still have an unsatisfactory prognosis compared to younger ones highlighting the need to develop more efficient therapies for this group of patients. Growing evidence indicates that macroautophagy (hereafter referred to as autophagy) is essential for health and longevity. This review is focusing on the role of autophagy in normal haematopoiesis as well as in leukaemia and lymphoma development. Attenuated autophagy may support early hematopoietic neoplasia whereas activation of autophagy in later stages of tumour development and in response to a variety of therapies rather triggers a pro-tumoral response. Novel insights into the role of autophagy in haematopoiesis will be discussed in light of designing new autophagy modulating therapies in hematopoietic cancers.
\end{abstract}

Keywords: macroautophagy; haematopoiesis; leukaemia; lymphomas; therapy response; ageing

\section{Introduction}

Macroautophagy-Janus-Faced Role in Cancer

Macroautophagy (henceforth autophagy) is a vesicular pathway through which cellular components are sequestered into a double membrane vesicle called the autophagosome and then 
delivered to lysosomes for degradation (Figure 1) [1]. Autophagy is induced in response to a variety of intrinsic and environmental stresses including nutrient and energy limiting conditions, endoplasmic reticulum stress, reactive oxygen species (ROS), hormonal imbalance and exposure to microorganisms [2]. Depending on the stimulus and context, autophagy can sequester bulk cytoplasmic components non-selectively or specific cargoes selectively with the help of autophagy-receptors [3]. Under metabolic demands, autophagy induction generates new precursor components, which are used by cells for energy supply to enable adaptation and cell survival [4]. Autophagy also plays a critical role in the quality control of intracellular components by promoting the removal and replacement of cytotoxic damaged organelles and proteins [5]. Such cellular renewal is especially important in long-lived as well as non-replicative cells such as quiescent and terminally differentiated cells. There is evidence that autophagy plays an essential role in physiological processes that orchestrate development, differentiation, cell survival and immune responses. Defective autophagy is linked to inflammatory and infectious pathologies, cancer, neurodegenerative disorders, liver diseases and ageing [6].

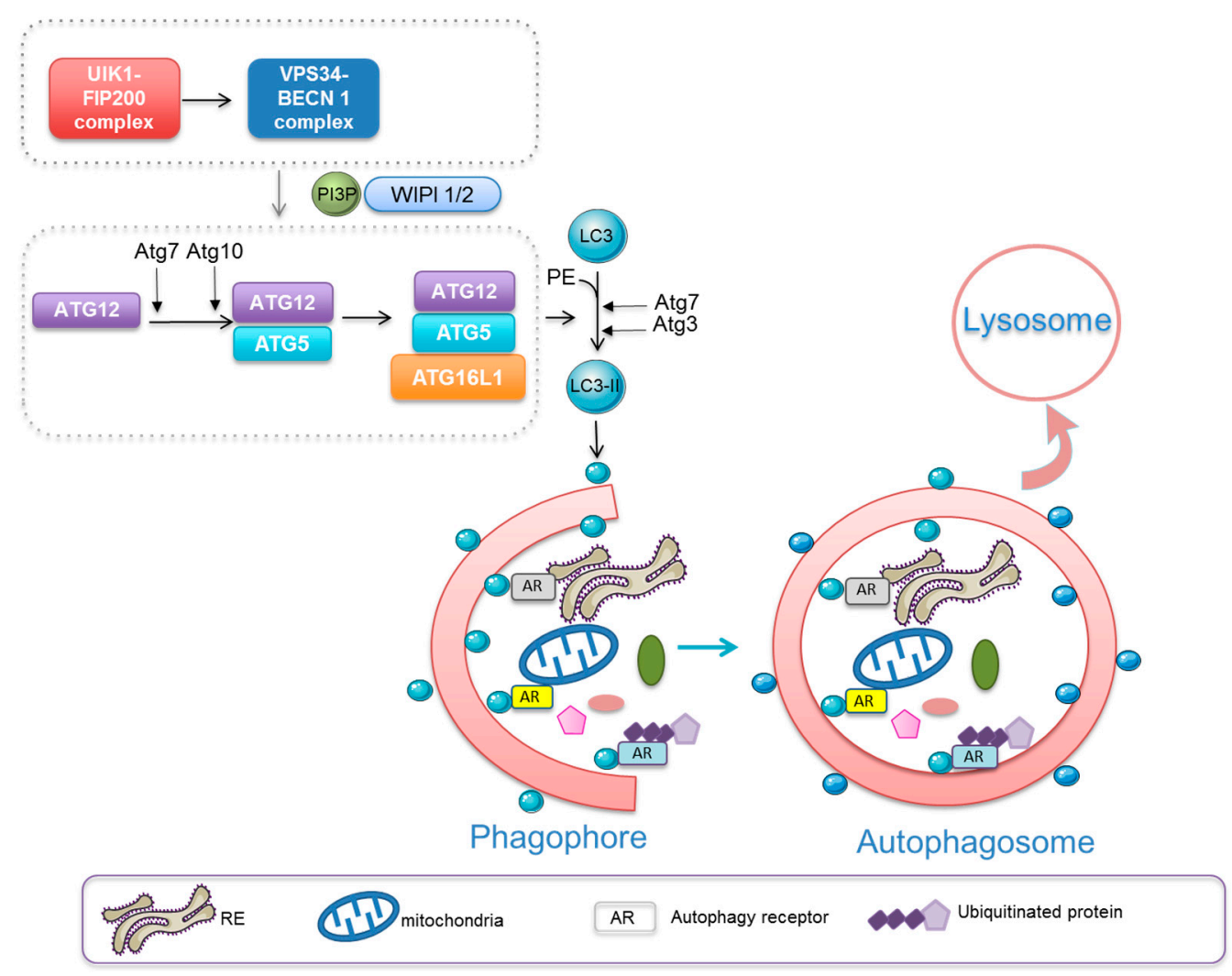

Figure 1. Autophagy occurs through a multistep process. The first step is the formation a double-membrane structure called the phagophore that requires the assistance of two complexes: the ULK1/FIP200 complex and the class III PI3K/BECN1 complex that allows the production of PtIns 3P which bind to WIPI proteins. Subsequently, the autophagosomal membrane expands to sequester cytoplasmic cargoes and to form a vesicle named the autophagosome. This step requires two ubiquitin-like conjugation systems, ATG5-ATG12/ATG16 and ATG8 (LC3-GABARAP)-PE. Apart from the ATG proteins, selective autophagy requires a subset of autophagic adaptors that recognize and bind to specific cargoes (e.g., proteins and mitochondria, endoplasmic reticulum) through ubiquitin-dependent and -independent mechanisms. Autophagy adaptors drive the cargoes to the autophagosomal membrane by binding to LC3/GABARAP-PE through their LIR domain. Finally, the sequestered cargoes are degraded by the lysosomal enzymes upon the fusion of autophagosome with the lysosome. 
Genetic studies of autophagy in yeast have led to the identification of autophagy (Atg)-related genes whose products drive autophagosome formation through a multistep process [7]. Upstream of the ATG proteins, several signalling pathways regulate autophagy including the mTOR pathway. Inhibition of mTOR leads to activation of the ULK1/Fip200 complex, which in turn promotes the stimulation of the class III PI3K/BECN1 complex. This subsequently leads to the production of PtIns $3 \mathrm{P}$ which operates as an initial signal for the formation of a phagophore or initiation membrane. WIPI proteins are PtIns3P binding effectors that allow the recruitment of several multiprotein complexes to the autophagosomal membrane including two ubiquitin-like conjugation systems, ATG5-ATG12-ATG16 and the ATG8 protein family (Microtubule associated protein 1 light chain (LC3)A, B, C, Gamma-aminobutyric acid receptor-associated protein (GABARAP), GABARAP like (GABARAPL) 1, GABARAPL2-phosphatidyl ethanolamine (PE) [8]. These steps are instrumental for the expansion and the closure of the autophagosomal membrane. The last step of autophagy is the degradation of the sequestered cargoes by lysosomal enzymes generating ATP as well as a pool of biomolecules. Selective autophagy requires additional proteins known as autophagic adaptors recruited at the autophagosomal membrane that recognize the cargoes via an LC3-interacting region (LIR) [1]. Several cellular components can be selectively degraded by autophagy for example mitochondria (mitophagy), aggregated proteins (aggrephagy) and the endoplasmatic reticulum (ER-phagy) [9]. Selective autophagy also requires cargo (proteins, mitochondria and pathogens) ubiquitination. In this scenario, autophagy adaptors recognize ubiquitinated cargoes through their ubiquitin binding domain. A subset of autophagy adaptors, including SQSMT1/p62, NBR1, Optineurin and NDP52 operate in selective autophagy through such ubiquitin-dependent mechanisms [10]. Selective autophagy can also occur through an ubiquitin-independent mechanism wherein autophagy adaptors such NIX and FAM134B bind directly to mitochondria and the endoplasmic reticulum (ER), respectively [11,12].

Basal macroautophagy is crucial for maintaining cellular homeostasis in resting cells and also for their proliferation and differentiation [13,14]. In the context of cancer the role of macroautophagy is complex and clearly depends on tumour stage, type and the driving oncogene. In healthy individuals autophagy is regarded as a longevity promoting and tumour suppressing process mainly due to its function to protect cells against genotoxic stress [15]. However, many studies described a tumour-promoting role for macroautophagy once a tumour has formed as well as during metastasis by supporting cancer cell survival. Furthermore, therapy-resistance mechanisms may be based on protective autophagy activated in response to therapy-induced stress [16-20].

In this review, we will summarize the knowledge on autophagy function in healthy hematopoietic cells and the consequences of its deregulation leading to hematopoietic malignancies. In addition, we will give an overview on the effect on autophagy-based pre-clinical therapies in hematopoietic cancers and their potential to improve current therapies. The regulation of autophagy during haematopoiesis has been recently reviewed in Biochemical Pharmacology [21].

\section{Haematopoiesis Development and Autophagy}

\subsection{Haematopoiesis}

Haematopoiesis is a tightly orchestrated physiological process that leads to the generation of all blood cells from a small population of hematopoietic stem cells (HSCs) [22]. HSCs reside in a hypoxic stromal niche within the bone marrow in adults where they maintain their quiescent and self-renewal capacity. HSCs can divide symmetrically, producing two identical daughter HSCs or asymmetrically producing one HSC and a more proliferative cell primed for differentiation. Through these hierarchical events, HSCs produce functionally differentiated progenies, namely myeloid (erythrocytes, megakaryocytes, monocytes, neutrophils, basophils or eosinophils) and lymphoid (T- and B-lymphocytes) cells [23]. 
The self-renewing capability of HSCs allows the lifelong maintenance of an HSC pool. HSCs may acquire mutations leading to a defect in the replenishment of mature blood cells resulting in clonal haematopoiesis or hematopoietic diseases. Therefore, HSCs have developed several adaptive strategies to cope with stressful conditions enabling maintenance of hematopoietic homeostasis [24]. Autophagy is one of the key adaptive mechanisms that occur during haematopoiesis. Here we summarize some recent discoveries that shed new light on the role of autophagy in normal and malignant haematopoiesis (Figure 2).

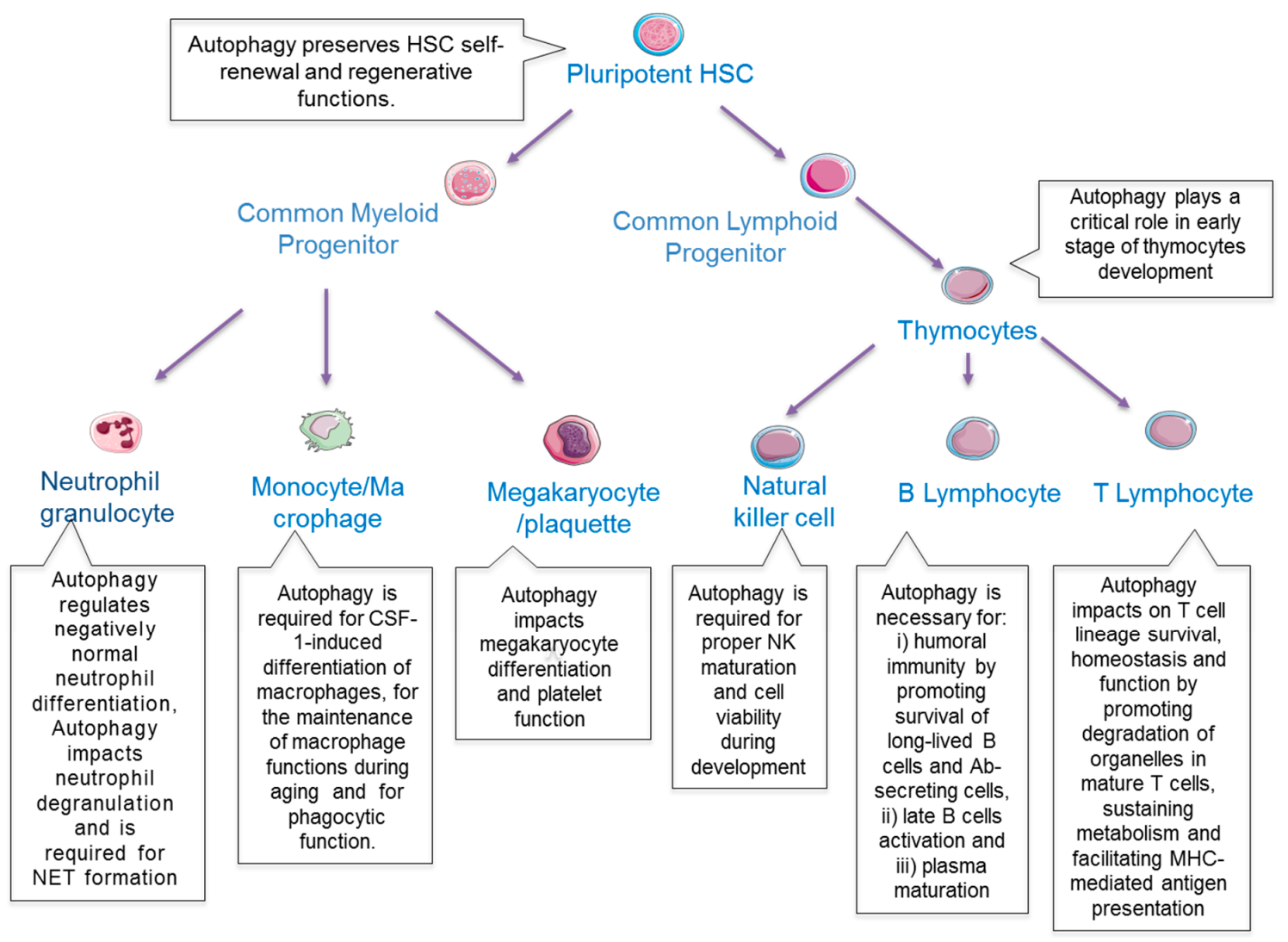

Figure 2. Examples of key functions of autophagy in blood cells.

\subsection{Autophagy in HSCs}

While HSC rarely cycle and are maintained mainly in a quiescent state (G0 phase of the cell cycle) under homeostatic conditions, they can produce billions of mature cells needed in adult human and maintain a pool of HSCs for the entire life of the organism $[25,26]$. Therefore, HSCs sustain a tight balance between quiescence and active state. Aged HSCs show a reduced potential to regenerate the whole blood system since they are biased towards myelopoiesis [27-30]. Furthermore, old HSCs show reduced long-term repopulation coupled with reduced chromatin regulation and DNA repair gene expression while genes involved in inflammatory response and stress response are upregulated [31]. Interestingly, while the long-term HSCs population decreased with age, the hematopoietic progenitor cells (HSPCs) compartment is increased leading to clonal haematopoiesis.

Several reports demonstrated a key role of autophagy in HSCs maintenance and function. The conditional deletion of the essential autophagy gene Atg7 in murine HCSs resulted in accumulation of aberrant mitochondria paralleled by an increase in ROS levels resulting in a drastic increase of DNA damage. Furthermore, the HSC compartment is reduced whereas myeloid progenitors are increased in these mice shifting the differentiation balance towards myelopoiesis [32] similarly to an aged HSC phenotype. Comparable phenotypes were observed when FIP200-a protein of the ULK1/FIP200 complex-was deleted in HSCs, reiterating the role of autophagy in HSCs development [33]. 
Interestingly, Atg7 deletion promotes a distinct outcome in HSCs and myeloid cells. In HSCs, Atg7 deletion promotes irreversible impairment of autophagy and causes death. On the other hand, Atg7 deficiency in myeloid cells initiates an alternative compensatory autophagy pathway that enables cell viability [34]. This suggests that HCS are more vulnerable to autophagy deficiency than differentiated cells. Indeed, under metabolic stress, long-term HSCs survive by inducing autophagy [34].

Basal levels of autophagy has been shown to control normal HSC differentiation potentially through a mechanism that involves ROS-mediated degradation of the active form of NOTCH [35,36]. Furthermore, basal level of autophagy is essential for removing activated mitochondria and controlling the metabolism of young and old HSC which ultimately preserve HSC self-renewal capacity and regenerative potential [37]. Autophagy was also activated when HSCs were subjected to metabolic stress. Under this condition, autophagy enables cell survival through a mechanism that relies on a FOXO-3-driven pro-autophagy gene program [34]. Hence, the fine-tuned regulation of basal and enhanced levels of autophagy is necessary for proper function and survival of HSCs.

Together, HSCs with impaired autophagy are more prone to ageing leading to increased risk of developing hematopoietic malignancies. Therefore, further studies on autophagy and aging are needed to develop novel strategies to prevent premature aging of HSC.

\subsection{Autophagy in Development and Differentiation of Lymphocytes}

Lymphocytes are comprised of T-, B- and the natural killer cells (NK). T- and B-cells are the major cellular components of the adaptive immune response [38,39].

\subsubsection{T Lymphocytes}

T cells develop from self-renewing bone marrow HSC. Upon entering the thymus, multipotent progenitors develop towards T-cells and loose self-renewal capacity [40]. During thymic differentiation in mice thymocytes progress from double negative (DN, CD4 CD8) to double positive (DP, CD4+CD8+) stages. A first critical checkpoint in the thymus takes place at the DN3 stage, marked by the rearrangement of the TCR $\beta$ gene. Following successful rearrangement, the $\beta$ chain pairs with an invariant $\mathrm{pT} \alpha$ chain to form the pre-TCR that drives cell survival, proliferation and differentiation through the DN4 to the DP stages. At this point, successful rearrangement of the TCR $\alpha$ gene allows for the pairing of the $\alpha / \beta$ chains to produce a functional TCR. Mature single positive T lymphocytes are then released into the periphery. Thus, the recombinases $(\operatorname{Rag} 1 / 2)$ that rearrange TCR genes are active at the DN3 and DP stages.

Experiments in chimeric mice generated by transplantation of Atg5 or Atg7 knockout foetal liver cells into lethally irradiated congenic host demonstrated that mice with impaired autophagy show normal $\mathrm{T}$ cell development but cannot fully reconstitute the lymphoid compartment due to a drastic increase in cell death in the peripheral compartment [41,42]. Furthermore, while expressing normal TCR levels, Atg5 $5^{-/}$T cells failed to undergo efficient proliferation after TCR stimulation [41] potentially due to an increase in mitochondria mass [42]. TCR stimulation led to activation of autophagy [43] that restrained activation of a ligand-initiated signalling cascade by inhibiting the NF-KB signalling pathway [44].

Autophagy plays a dual role in $\mathrm{T}$ cell subsets depending on the stage of differentiation. Even though autophagy is critical for mature $\mathrm{CD} 4^{+} \mathrm{T}$ cell death after growth factor withdrawal or in $\mathrm{T}$ cells lacking FADD activity, caspase 8 or Irgm-1 [45,46], it is linked to survival in other subsets. In T helper 9 cells, autophagy is required for selective degradation of PU-1 which represses differentiation and anti-tumour activity of these cells [47]. In addition, autophagy has also been shown to be critical for the survival integrity of regulatory $\mathrm{T}$ cells and the maintenance of long-lived memory $\mathrm{T}$ cells, presumably by facilitating the cell adaptation to changing in metabolic demands [48,49]. Moreover, Zhu et al. showed that TBK-binding protein 1 regulates IL-15-induced autophagy in NKT cells and this response operates as a regulator of NKT cell development and survival [50]. 
Further studies on the role of autophagy in T cell functions at various developmental stages are still needed to have full comprehension of its role during this process.

\subsubsection{B Lymphocytes}

$B$ cells undergo differentiation through several stages from pro-B, pre- $B$ and immature $B$ to mature B-cells. Upon an immune response, B cells are activated and then fully differentiate into plasma cells, which secrete antibodies against infectious pathogens or for example cancer cells [51].

Reconstitution of irradiated $\mathrm{Rag}^{-/-}$mouse with $\mathrm{Atg} \mathrm{S}^{-/-}$foetal liver cells demonstrated a reduction in peripheral $B$ cells and reduced $B$ cell survival during the final stage of differentiation within the bone marrow (pro-B to pre-B transition) [52]. Using a conditional Atg5 knockout mouse model under the control of CD19 or Mb1 promoter, Miller et al. and Arnold et al. demonstrated that autophagy plays a critical role in humoral immunity through promoting survival of long-lived $\mathrm{B}$ cells and Ab-secreting cells but it is dispensable for pre-B cell transition and B-cell activation under B-cell receptor stimulation [52,53]. Therefore, complete and partial inhibition of autophagy has distinct outcomes in B lymphocyte development. Furthermore, autophagy is necessary for the survival of specific memory B cells but not for the initial generation of memory B cells [54,55]. In addition, WIPI-2 dependent non-canonical autophagy is crucial for B cell activation and mitochondria homeostasis [56]. In line with these data, plasma cells maintenance and antibody response have been shown to be regulated by an ATG5 dependent autophagy [57].

\subsubsection{NK Cells}

NK cells are the major component of the innate immune response and serve as a first line of defence against cells harbouring a variety of perturbations such as malignant transformation or viral infection. They are part of the recently define innate lymphoid cells family. An NK cell progenitor specific Atg5 knockout mouse model revealed a crucial role of autophagy in differentiation of these cells $[58,59]$. Furthermore, the proper association of FOXO1 and ATG7 on the phagophores is needed for the appropriate activation and development of functional NK cells in mice [58].

Moreover, NK cells are crucial for tumour immunosurveillance [60]. Thus, a better understanding of the role of autophagy in this particular lymphocyte subset is crucial for future immunotherapy targeting cancer cells. Indeed, inhibition of the autophagy gene BECN1 in solid tumours induced a massive NK cells infiltration leading to tumour growth inhibition [61,62].

\subsection{Autophagy in Development and Differentiation of Erythrocytes}

During erythropoiesis, cells undergo substantial ultrastructural changes including the removal of nuclei and other intra-cellular organelles. Therefore, it did not come as a surprise that autophagy is critical in this process. Earlier studies suggested that autophagy is involved in the elimination of mitochondria during terminal differentiation of embryonic erythrocytes [63]. Accordingly, the abundance of autophagy vesicles and multi-vesicular bodies has been observed in K562 erythroid cells that underwent differentiation upon hemin treatment [64]. This induction of autophagy relies on the master regulator of haematopoiesis, GATA-1 which has been shown to directly activates gene involved in autophagy [65].

While inhibiting autophagy in K562 cells by knocking out ATG7 or treatment with Bafilomycin A1 led to a reduction of $\alpha$-globin and $\gamma$-globin, the opposite was found when autophagy was activated in K562 cells using rapamycin, starvation or in Atg7 knockout mouse model [66]. Earlier studies suggested that autophagy is involved in the elimination of mitochondria, referred to as mitophagy, during terminal differentiation of embryonic erythroid cells. NIX (or BNIP3), a BH3-only family member is upregulated during erythroid differentiation [67]. Interestingly, NIX is required for sequestration of mitochondria into the autophagosome during terminal erythroid differentiation $[68,69]$ and interacts directly with GABARAP [70]. Furthermore, during maturation of erythrocytes, autophagosome maturation is dependent on ATG4 [71]. 
The importance of autophagy during erythropoiesis is further highlighted by several autophagy knockout mouse models. Indeed $A \operatorname{tg} 7^{-/-}, \mathrm{Ulk1} 1^{-/-}$and $\mathrm{Nix}^{-/-}$murine erythrocytes are not able to degrade mitochondria $[32,72,73]$. Interestingly, only $U l k 1^{-/-}$erythrocytes have impaired ribosomal clearance suggesting that several distinct pathways are involved in selective degradation of organelles by autophagy during maturation of erythrocytes. One mechanism proposed for the regulation of mitophagy during erythroid differentiation is the requirement of ATG13 to unwanted mitochondria following binding of ULK1 to Hsp90-Cdc37 chaperone complex [74].

Erythropoiesis is aslo regulated by the neutral sphingomyelinase/ceramide axis. The activation of this pathway leads to myelopoiesis through a mechanism that involves the inhibition of autophagy and the modulation of the hematopoietic transcription factors (TFs) GATA-1, GATA-2 and PU.1 [75]. Moreover, NCOA4, a cargo receptor involved in the autophagic turnover of ferritin plays an essential role during erythroid differentiation as evidenced by defective erythropoiesis in NCO4A K562 knockdown cells and a Ncoa4 zebra fish knockout model [76].

\subsection{Autophagy in Development and Differentiation of Macrophages, Neutrophils and Megakaryocytes}

During haematopoiesis, HSCs give rise to multi-potent progenitors (MPPs) that subsequently generate intermediate lineage restricted progenitors. In myeloid differentiation, common myeloid progenitors (CMP) give rise to granulocyte-macrophage (GM) and megakaryocyte-erythroid (MkE) progenitors that subsequently develop in differentiated myeloid cells.

\subsubsection{Macrophages}

Unstimulated monocytes in circulation are short living cells. Stimuli that induce monocyte-macrophage differentiation induce structural changes and impair the apoptotic program of monocytes [77,78]. Macrophages are key players in innate immune responses to acute and chronic inflammation. During monocyte-macrophage transition induced by GM-CSF, an autophagic survival program is activated $[79,80]$. Interestingly, M-CSF induced differentiation led to an activation of autophagy but inhibiting key ATG genes did not affect the survival of these cells. These data were confirmed in an Atg7 knockout mouse model [79]. While GM-CSF stimulation resulted in activation of the MAPK8/JNK1 pathway, M-CSF activates a CAMKK2-PRKAA1 pathway [79,80]. Therefore, further studies are necessary to clarify the interplay between the different kinase cascades, which lead to autophagy activation during macrophage development. Moreover, inhibition of autophagy impairs the ability of mature monocytes to phagocyte bacteria suggesting a role for autophagy in phagocytic function. The activation of autophagy during macrophagic differentiation of monocytes relies on the activation of CAMKK2-PRKAA1-ULK1 pathway and the purinergic receptor P2RY6 [81]. The role of P2RY6 in autophagy regulation was further supported by data showing that the P2RY6 ligand UDP and the specific P2RY6 agonist MRS2693 can restore normal monocyte differentiation through reactivation of autophagy in primary myeloid cells of chronic myelomonocytic leukaemia (CMML) patients. Apart from its role in macrophagic differentiation, autophagy is implicated in the maintenance of macrophage functions during aging. Indeed, deficiency of autophagy due to the loss of Atg7 gene causes phenotypes similar to aged macrophages including reduced macrophage functions (i.e., phagocytosis and nitrite burst) and pro-inflammatory responses [82]. Therefore, autophagy regulates macrophage homeostasis and function which have potential relevance for the prevention of inflammatory diseases, which progressively increase with age.

Importantly, autophagy is also influencing the alternative activation of macrophages (M2) [83]. Inhibition of autophagy led to a pro-M2 like polarization while activation of autophagy results in impaired alternative activation of macrophages. Interestingly, tumour associated macrophages (TAM) more frequently represent the M2 subtype. Together, deciphering the role of autophagy during macrophage differentiation and activation will contribute to a better understanding of myeloid leukaemia development and may provide new strategies to target TAMs in cancer. 


\subsubsection{Neutrophils}

Neutrophils are the most abundant cell type of the innate immune response. After stimulation, neutrophils can for example degranulate or release chromatin, nuclear histone protein and serine proteases to form neutrophil extracellular traps (NETs) [84]. Unbalanced NETs formation has been linked to autoimmune pathogenesis and inflammatory disorder [85]. The use of 3-Methyladenine or Ammonium Chloride (NH4CL) as inhibitor of autophagy led to increased NET formation in neutrophils [86] suggesting that autophagy may play a protective role in NET formation although these data should be confirmed using more specific autophagy inhibitors. Furthermore, Remijsen $Q$ et al. showed that both autophagy and superoxide generation are required for NET cell death [87]. In the same vein, Kajiume et al. recently demonstrated that human neutrophils undergo autophagic cell death rather than apoptosis [88].

During granulopoiesis, characterized by development from myeloblasts (MB), to promyelocytes $(\mathrm{PM})$, myelocytes (MC), metamyelocytes (MM), band cells (BC) and finally segmented granulocytes $(\mathrm{PMN})$ cells acquire specific morphologic features and generate granules [89]. Interestingly, during these different stages autophagy flux first decreases (MB to $M M)$ to then significantly increase (BC to PMN) sustaining the metabolic reprogramming during neutrophil differentiation [90].

As macrophages, neutrophils can support tumorigenesis and metastasis formation [91]. For example, exosomes secreted by gastric cancer cells cause activation of autophagy in neutrophils by activating the NF-KB pathway through HMGB1/TLR4 [92]. Similarly, patients with systemic sclerosis show increased neutrophil levels with activated autophagy due to the release of platelet-derived microparticles enriched in HMGB1. Thus, autophagic neutrophils demonstrated an enhanced mobilization of their granules, proteolytic activity, prolonged survival and NETs formation [87,93-96].

Mouse neutrophils deficient for ATG7 or ATG5 are impaired in degranulation of primary and secondary granules [97]. Interestingly, while autophagy-deficient neutrophils circulate more and are more prone towards recruitment to the site of inflammation, they have reduced effector functions. In line with this observation, it has been shown that neutrophils secrete IL-1 $\beta$ via autophagy mediating inflammation [98].

Together, the importance of autophagy during neutrophil development and function highlights its relevance in both immunity and cancer development.

\subsubsection{Megakaryocytes}

Megakaryocytes (MK) are precursors of platelets that are formed from MK cytoplasm. During maturation, megakaryocytes undergo endomitosis and therefore become polyploid. Then, they extend long branches into blood vessels, also known as proplatelets that upon fission become platelets [99]. In $A \operatorname{tg} 7^{-/-}$mice megakaryocyte differentiation is impaired due to increased apoptosis and decreased polyploidy [100].

In mouse models, depletion of Atg7 or Becn1 resulted in lower platelet numbers with increased size in the peripheral blood $[100,101]$. In addition, $A t g 7^{-/-}$and $A t g 7^{+/-}$platelets activation and aggregation were decreased compared to wild type platelets [100]. Accordingly, Becn1 $1^{+/-}$mice demonstrated an increased bleeding time and aggregation [101]. These findings were confirmed in human cells [101].

\section{Autophagy and Lymphoid Tumours}

\subsection{Aberrant Autophagy in Lymphomas and Lymphoid Leukaemia}

\subsubsection{Lymphomas}

Diffuse large B-cell lymphoma (DLBCL) accounts for 33\% of B-Non-Hodgkin Lymphoma and is the most common subtype. It corresponds to the malignant counterpart of germinal centre (GC) and post-GC activated cells and is characterized by a diffuse proliferation of large cells harbouring a high 
mitotic rate. This is an aggressive lymphoma, which arises de novo or is the result of the clinical evolution of less aggressive B-NHL types (like FL and CLL). DLBCL have been subdivided in three major molecular entities based on gene expression analysis [102]: (a) the germinal centre B-cell like derived (GCB) DLBCL, (b) the activated B-cell like (ABC) DLBCL which are related to BCR-activated B cells or $B$ cells committed to plasma cell differentiation and (c) primary mediastinal $B$ cell lymphoma (PMBCL), which arise from post-GC thymic B cells. GCB and ABC subtypes often occur in older male adults (median age: 64 years) whereas PMBCL develops in younger adult women. The GCB subtype is mainly characterized by BCL-2 overexpression, the ABC subtype by NF- $\mathrm{kB}$ constitutive activation and BCL- 6 overexpression and the PMBCL subtype by amplification of genes involved in T cells immunomodulation. The GCB subtype can be cured by chemoimmunotherapy, whereas more than $50 \%$ of the patients presenting the $\mathrm{ABC}$ subtype will relapse and die from their malignancy. Recently, the 2016 World Health Organization classification for lymphomas included a new category termed high grade B-cell lymphoma with translocations involving MYC and BCL-2 or BCL-6 [103]. Interestingly, BCL-2 inhibits autophagy by direct binding to BECN1. In line with these observations, patients with a decreased BCL-2 levels have an increase in BECN1 expression that correlates with a favourable clinical outcome $[104,105]$. In accordance, $B e c n 1^{+/-}$mice demonstrated a higher frequency of cancer incidence such as lung, liver cancer or B cell lymphoma [106,107]. Another study indicated that the constitutive repression of autophagy responses in BCL-6-driven DLBCL may contribute to lymphomagenesis [108]. On the contrary, Li Y. et al. observed a link between Cullin4B (CUL4B) (a scaffold protein of the CUL4B-RING E3 ubiquitin ligase complex, highly expressed in DLBCL) and autophagy in the positive regulation of DLBCL progression. They showed that CUL4B regulating autophagy occurred through JNK signalling and that the inhibition of proliferation induced by CUL4B deletion may be attributed to the blocking of the pro-survival ability mediated by autophagy [109]. This last study highlights the complexity of autophagy regulation in DLBCL and the necessity to improve our knowledge on the role of autophagy in lymphoma development.

B-cell Chronic Lymphocytic Leukaemia (B-CLL)/small lymphocytic lymphoma (SLL) is mainly a disease of older adults (median age: 70 years), characterized by inherent defects in cell death. This leukaemia/lymphoma progresses slowly and, when patients present clinical symptoms affecting their quality of life, they are treated by chemoimmunotherapy. El-Khoury et al. demonstrated that inhibition of autophagy by RNA interference targeting key autophagy genes or by using Chloroquine or 3-Methyladenine in PBMCs from CLL patients decreased cell viability [110] suggesting that B-CLL cells are dependent on autophagy. In line, an $\mathrm{I} \kappa \mathrm{B} \zeta$ mouse model revealed that $\mathrm{I} \kappa \mathrm{B} \zeta$ controls B-lymphocyte proliferation and triggers a Toll-like receptor (TLR)-dependent antibody response [111]. Interestingly, autophagy is required for TLR9-dependent secretion of IgM in I $\mathrm{B} \zeta$, positive CLL [112]. In addition, high expression of class 3 PIK3, PIK3R4 and BECN1 are associated with poor outcome in this disease [113].

DAPK1 is an autophagy-associated gene that is frequently silenced in tumours [114]. Interestingly, DAPK1 is inactivated in rare CLL cases by mutations leading to increased binding of HOXB7 to the DAPK1 promoter [115]. Gade et al. demonstrated that loss of DAPK1 expression in CLL is due to a dysfunctional CEBP- $\beta$ /ATF6 pathway. Furthermore, the inhibition of DAPK1 reduces autophagy and promotes CLL cell growth [116]. This last study points again to the dual role of autophagy in cancer which was supported by other reports. For instance, signaling-lymphocytic-activation-molecule-family1 (SLAMF1) expression is associated with favourable prognosis in CLL cells and is lost in patients with an aggressive form of this disease [117]. Bologna et al. demonstrated that SLAMF1 activates autophagy activity by indirectly stabilizing the BECN1-VPS34 complex. Accordingly, SLAMF1 negative cells are less sensitive to autophagy-inducing therapy [117].

Mantle cell lymphoma $(M C L)$ is an aggressive disease that constitutes about $5 \%$ of B-NHL and rather occurs in older adults. The majority of the patients are treated by immunochemotherapy. Relapses are frequently observed and are mainly treated with the proteasome inhibitor, Bortezomib, [118] or the mTOR inhibitors, Temsirolimus/Everolimus. Indeed, since mantle cell lymphoma overexpress 
cyclin D1, a key protein involved in the G1/S transition phase and regulated by mTOR signalling, this lymphoma was the first hematologic disease in which the therapeutic efficiency of mTOR inhibitors was investigated [119]. However, the prognosis of patients is dismal and MCL is still considered as an incurable disease, in needs for new therapeutics. It is essentially considered as the malignant counterpart of naïve B cells located in the inner mantle zone of secondary follicles. This lymphoma is characterized by the overexpression of cyclin D1 due to the $t(11 ; 14)(q 13 ; q 32)$ chromosomal translocation.

MCL patients express high levels of TG2 and NF- $\mathrm{BB}$ [120]. Lowering TG2 in MCL cells decreases proliferation and survival rates. Furthermore, TG2 regulates autophagic flux while inhibiting autophagy by silencing ATG5 resulted in undetectable TG2 levels. In this context, ATG5 knockout cells proliferate at a lower rate compared to autophagy-proficient cells.

Phospholipid scramblase 1 (PLSCR1) is a pro-apoptotic gene upregulated upon 9-cis-retinoic acid and Interferon-a treatment in MCL cell lines [121,122]. Interestingly, PLSCR1 inhibits autophagy activity reducing MCL cell viability [123].

On the contrary, the hedgehog $(\mathrm{hH})$ pathway in MCL cells promotes the infiltration of cells to the bone. Inhibiting the $\mathrm{hH}$ pathway using LDE225 treatment increased CXCR4 expression levels and ROS leading to enhanced autophagic activity and cell survival [124].

Burkitt Lymphoma $(B L)$ is an aggressive immature B-cells disease, characterized by MYC gene rearrangement, positivity for early $B$ cell markers and a high mitotic rate. This is a rare disease in adults (1-2\% of B-NHL), whereas it accounts for $30 \%$ of paediatric lymphomas. These patients are treated by chemoimmunotherapy. Relapsed tumours have dismal prognosis.

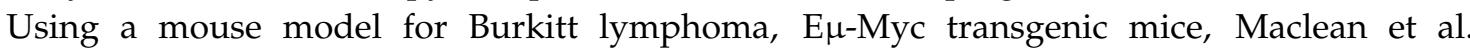
demonstrated that disruption of lysosomal function using Chloroquine prevents lymphomagenesis linking this disease to autophagy [125].

Multiple Myeloma (MM) is a cancer of plasma B cell, invading the bone marrow and characterized by a high genomic and phenotypic variability [126]. It corresponds to the unrestrained proliferation of fully differentiated B cells, which excessively produce and secrete monoclonal immunoglobulins. Treatment options have evolved from chemotherapy $[127,128]$ to targeted therapies, including the use of proteasome inhibitors [129], immunomodulatory drugs [130] and chaperone protein inhibitors [131]. However, responses are not durable and MM still represents an incurable disease. This disease primarily occurs in elderly individuals (median age: 69 years). A risk loci for predisposition to MM is mapped to intron 6 of ATG5 on chromosome 6q21 [132,133]. In addition, high expression of BECN1 or LC3 is associated with a favourable outcome in MM [134]. These two observations suggest a disruption of autophagy is critical in MM disease development, while others demonstrate that autophagy activation is necessary to induce MM survival. Indeed, a recent study described the role of myeloid-derived suppressor cells (MDSC) in promoting MM cell survival and proliferation by activating the AMPK pathway. The authors propose that the pro-survival effect of AMPK may be attributed to the induction of autophagy [135]. Gao D. et al. reported also, in bone marrow cells from patients with untreated MM, the high expression of the long non-coding RNA MALAT and of HMGB1, leading to the promotion of autophagy and survival [136].

The anti-apoptotic CHE-1 protein interacts with RNA polymerase II and regulates gene transcription. Its expression correlates with the progression of $\mathrm{MM}$ and is required for cell growth and survival. Interestingly, CHE-1 is phosphorylated upon cellular stress and binds to the Redd1 and Deptor promoters where it activates their transcription and consequently attenuates mTORC activity. CHE-1 expression induces autophagy activity by interfering with both mTORC1 and mTORC2 thereby linking autophagy to survival and progression of MM [137]. In line with these results, several studies demonstrated that inhibition of autophagy reduce MM cell survival $[138,139]$. Surprisingly, other studies pointed towards a pro-cell death role of autophagy in MM [140,141].

Primary Effusion Lymphoma (PEL) is a very rare B-cell NHL associated with HHV-8/EBV infections and is mostly observed in human immunodeficiency virus (HIV) positive individuals [142]. 
PEL present clinically, in its classic form, as malignant lymphomatous effusions in body cavities (pleural, peritoneum, pericardium cavities). Extracavitary PEL, characterized by solid mass lesions, has also been reported [143].

In a recent study, Masud Alam et al. demonstrated that the inhibition of lysosomal degradation using Chloroquine in PEL cells induced ER stress and subsequent apoptosis, thus suggesting that autophagy supports cellular survival in PEL [144].

Interestingly, treatment of PEL cells with Epigallocatechin-3-Gallate (EGCG), the major constituent of green tea, led to suppression of HHV8 replication and ROS production that subsequently induces autophagy and apoptosis [145]. This last study demonstrates that the role of autophagy in PEL development needs more clarification.

Anaplastic Large Cell Lymphoma (ALCL), ALK (Anaplastic Lymphoma Kinase) positive account for $1-3 \%$ of adult T-NHL but correspond to $15 \%$ of childhood lymphoma [146]. This malignancy is currently treated by chemotherapy (based on anthracyclines) but refractory or relapsed diseases invariably occur in 30\% of the patients, regardless of the drugs and doses used [147]. This lymphoma is predominantly driven by the NPM-ALK oncogene, encoded by the $t(2 ; 5)(p 23 ; q 35)$ [148]. Since NPM-ALK is a constitutively active tyrosine kinase $[149,150]$, small molecule inhibitors, such as the first in line Crizotinib [151], have been developed over the past 10 years [152,153]. So far, such targeted therapies have been hampered by the acquisition of resistance to the drug $[154,155]$. Recently, new promising therapeutic modalities have emerged [146,156,157].

The role of autophagy in ALK+ ALCL development has not been studied so far. Using patient derived cell lines, a single study demonstrated that the inhibition of autophagy by either siRNA directed to ATG7 or Chloroquine alone did not significantly affect cell viability [158].

Follicular Lymphoma (FL) represents about $20 \%$ of B-NHL, placing it as the second most common lymphoma. It arises in older adults (median age: 60 years) and corresponds to the malignant counterpart of normal germinal centre B cells. Tumour cells commonly invade the bone marrow and are characterized (in $85 \%$ of the cases) by the overexpression of the anti-apoptotic protein BCL-2, as a result of the $\mathrm{t}(14 ; 18)$ (q32; $\mathrm{q} 12)$ chromosomal translocation. Other mutations, notably in different epigenetic modifiers such as the mixed-lineage leukaemia 2 (MLL2) protein (a histone H3 methylase), have been linked to the development of FL as well. This disease is the most frequent indolent lymphoma. However, it can evolve to DLBCL (in $20-30 \%$ of the cases) over time and it largely remains an incurable disease. The treatment of patients has greatly improved since the use of anti-CD20 monoclonal antibody-based therapy (called Rituximab (RTX)) [159], in combination with chemotherapy [160] or as a single therapeutic agent [161]. Recently, the immunological microenvironment has been proposed as an indicator of prognosis [162,163]. Those last years, new therapeutic options have emerged including immunomodulatory drugs, newer monoclonal antibodies, BH3-mimetics and kinase inhibitors. Regarding the autophagy regulation in B-cells, Mc Carthy et al. found that FL samples showed significantly decreased levels of both SQSMT1/p62 and LC3 compared with reactive B-cells, indicative of an increased autophagy activity in FL. This dysregulation of autophagy in human follicular lymphoma was found independent of overexpression of BCL-2 [164]. Interestingly, FL which express high LC3A levels also harboured a high HIF-1 $\alpha$ expression, suggesting a link between hypoxia and activation of autophagy in FL [165]. To our knowledge, no study on the role of autophagy in the disease development or sustainment has yet been performed.

\subsubsection{Acute Lymphoid Leukaemia}

Acute Lymphoid Leukaemias (ALL) account for $20 \%$ of acute leukaemia in adults and is the most common haematological malignancy in children. It is a heterogeneous disease harbouring different genomic abnormalities such as chromosome number or structure abnormalities, DNA copy number alterations and mutations. $80 \%$ of ALL arise from B cell precursors mainly (B-ALL) and $20 \%$ from thymocytes (T-ALL). Treatments classically involve chemotherapy (glucocorticoid, Vincristine and an anthracycline) but recent advances in genome profiling not only led to a better 
stratification of the disease but also to the development of new efficient targeted therapy for some specific subtypes [166-171]. As a consequence, the clinical outcome, notably of children with ALL, has considerably improved over the last years, with a cure observed in $80 \%$ of the cases. Concerning ALL in adults, only 25 to $50 \%$ of patients achieve long-term remission. Thus, new therapeutics are still needed to improve the outcome of patients.

Interestingly, a BECN1 splice variant was identified in the ALL cell line 697 with a deletion of exon 11. BECN1 Del-E11 demonstrated a reduction in autophagy induction [172]. Of note, 697 cells treated with Bafilomycin A1 have a reduction in engraftment in NOD/SCID mice. On the contrary, in a paediatric $\mathrm{t}(1 ; 19)$ pre-B acute lymphoblastic leukaemia (pre-B ALL) cell line model, induction of autophagy by either starvation or rapamycin leads to the degradation of DNA pold1 and RNA pol potentially inhibiting cell growth [173]. In line with these observations, the use of Torin-2 on pre-B ALL cells inhibited mTOR activity and increased autophagy paralleled by inhibition of cell growth and cell viability [174], pointing toward a tumour suppressor role of autophagy. Clearly, the role of autophagy in lymphoid malignancies is still debated and might be subtype specific. Therefore, further studies are needed to better understand the role of this recycling mechanism in lympho- and leukemogenesis.

\subsection{Autophagy-Based Treatment Strategies in Lymphomas and Lymphoid Leukaemia}

\subsubsection{Lymphomas}

Diffuse large B-cell lymphoma (DLBCL): Several studies related to the role of autophagy in DLBCL treatment have been recently published. In 2012, Jia et al. demonstrated that Bortezomib treatment of DLBCL promoted autophagy, which, through the degradation of IkBa, contributed to NF- $\mathrm{KB}$ sustained signalling and drug resistance [175]. They conclude that blocking both autophagy and proteasome pathways could have a great potential in killing DLBCL cells. Another group reasoned that since the phosphatidyl-inositol-3-kinase (PI3K)/Akt/mammalian target of rapamycin (mTOR) signalling pathway is often constitutively activated in DLBCL, treatment with the pan-class I PI3K inhibitor NVP-BKM120 could be beneficial in patients. Using different DLBCL cell lines, the authors showed that this compound decreased cell proliferation and induced apoptosis together with cytoprotective autophagy. Indeed, they further demonstrated that combining autophagy pharmacological inhibition (by using Chloroquine, 3-Methyladenine or Bafilomycin A1) with NVP-BKM120 further decreased DLBCL viability [176]. Yuan et al. demonstrated also that Tenovin-6 inhibited cell proliferation and survival of DLBCL by blocking autophagy [177]. SM1044, a newly synthetized antimalarial artemisinin derivative, demonstrated a significant anti-tumour effect on DLBCL cell lines. SM1044 induces autophagy that promotes Survivin degradation followed by apoptotic cell death [178]. Autophagy inhibitors abrogate SM1044-induced cell death. High expression of Survivin is associated with poor prognosis and can be overcome by inducing a selective degradation of Survivin by autophagy.

$\mathrm{Li}$ et al. found that the inhibition of the long non-coding RNA MALAT-1, in several DLBCL cell lines, resulted in autophagy activation and to a higher sensitivity to chemotherapy [179].

B-cell Chronic Lymphocytic Leukaemia (B-CLL)/Small Lymphocytic Lymphoma (SLL): Han et al. showed in 2008 that B-CLL cells resistance to TRAIL (TNF-related, apoptosis-inducing ligand) involved the induction of cytoprotective autophagy and that the inhibition of autophagy genes (Becn-1 and Atg5) sensitized the leukemic cells to the drug [180]. Along the same lines, Amrein et al. reported in 2011 that B-CLL cells treatment with Dasatinib, a tyrosine kinase inhibitor, induced cytoprotective autophagy (in a p53-dependent pathway) and drug resistance [181]. Finally, in 2012, Kovaleva et al. demonstrated that, independently to any drug treatment, miR-130a mediated autophagy inhibition (at early step in the autophagy process, through Atg2B and Dicer1 gene expression downregulation) drives B-CLL cells to cell death, thus pointing out the constitutive pro-survival role of autophagy in this disease [182]. Interestingly, the nucleoside analogue, 8-Chloro-adenosine that is in phase I-II clinical trial induces in vitro and in vivo autophagy in CLL [183]. Unfortunately, in the latter study, the authors did not investigate the impact of autophagy modulation on treatment response. 
A selective HDAC1, 2, 3 and 11 inhibitor, MGCD0103, triggers cell death in primary CLL cells by inhibiting autophagy $[110,184]$. Indeed combination treatment of Flavopiridol that induces protective autophagy, with MGCD0103 improves the efficacy of the treatment. Accordingly, in primary CLL cells, Tenovin-6, a Sirtuin targeting small molecule, induces cell death by inhibiting late stage of autophagy, thus preventing its protective effect $[185,186]$.

Recently, in a study aimed to understand the role of the bone marrow microenvironment in CLL resistant cells to Vorinostat treatment, Ding et al. found that autophagy in stroma cells fuels CLL cell growth and that its inhibition remarkably decreases stromal protection and overcomes the resistance to Vorinostat in CLL [187].

Mantle cell lymphoma (MCL): The cell survival-promoting role of autophagy in MCL has been reported in many studies. Zhang et al. found that under stress, the TG2 (transglutaminase 2)- NF- $\mathrm{kB}$ -IL6 signalling pathway triggered autophagy to promote cell survival, lymphoma progression and drug resistance [120]. The same group also demonstrated that the CXCR4/SDF-1 signalling pathway led to autophagy activation, acting as a survival mechanism upon MCL dissemination in the bone marrow [188]. Another study by Mastorci et al. has shown that the 9-cis-retinoic acid (RA)/Interferon (IFN)- $\alpha$ combination increased phospholipid scramblase 1 (PLSCR1) expression and led to the inhibition of cytoprotective autophagy through direct interaction and blockade of the ATG12/ATG5 complex. As a consequence, the authors also demonstrated that the combination of RA/IFN- $\alpha$ with chemotherapy or proteasome inhibitor enhanced apoptosis [123]. Another drug, Flavopiridol, a cyclin-dependent kinase inhibitor (CDKI), was also shown to be effective in MCL cells. However, cytoprotective autophagy restrained its tumour suppressing effect. The combination of 17-AAG (Hsp90 inhibitor) with Flavopiridol enhanced tumour cell apoptosis through BECN-1 degradation, ERK inactivation and autophagy suppression [189]. Finally, autophagy mediated degradation of CD74 was shown to restrain the efficiency of anti-CD74 monoclonal antibody Milatuzumab and to protect MCL cells from such immunotherapy $[190,191]$. Alinari et al. described how the synthetic sphingosine analogue, FTY720, potentiated the Milatuzumab onco-immunosuppressive effects in MCL by blocking the autophagy-lysosome dependent degradation of CD74 [190]. Altogether, these studies clearly highlight the cytoprotective role of autophagy in MCL, thus opening up a new therapeutic strategy, based on autophagy inhibition, to improve MCL patient's outcome.

Bortezomib induces NOXA stabilization in MCL cells. Interestingly, inhibition of autophagy by either 3-Methyladenine or Orlistat potentiates NOXA stabilization induced by UPR-inhibition leading to a significant cell death increase [192]. Accordingly, RAD001 induces apoptosis in the majority of MCL cells with low cytotoxic effect on normal T and B cells [193]. Interestingly, RAD001 MCL resistant cells have high autophagic activity compared to responding cells that is linked to their ability to escape the treatment. The resistance can be overcome by the use of Chloroquine.

In a subset of haematological cell lines, including myeloid leukaemia, lymphoid leukaemia, $\mathrm{T}$ cell lymphoma and mantle cell lymphoma, Nahimana et al. first demonstrated in 2009 that the treatment of the different cell lines with APO866 (an inhibitor of nicotinamide phosphoribosyltransferase (NAMPT), a key enzyme in nicotinamide adenine dinucleotide (NAD) biosynthesis) promotes cell death associated to autophagy induction [194]. A few years later, the same group further confirmed in a broad panel of haematological cancer cell lines (including T-acute lymphoblastic leukaemia (T-ALL), Burkitt lymphoma (BL), acute myeloid leukaemia (AML), multiple myeloma (MM)) and primary cells isolated from patients with AML and B-CLL that autophagy was indeed essential for APO866 cytotoxic effects [195]. Mechanistically and chronologically, autophagy was found to be activated first (as evidenced by LC3 turnover assay, puncta formation and SQSMT1/p62 degradation) and responsible for the degradation of CAT/catalase, a main cellular antioxidant, thus resulting in an increase in ROS levels, delayed caspases activation and subsequent cell death. Indeed, autophagy inhibition (especially through shRNA targeting ATG5, ATG7 but not through shRNA targeting BECN1) or CAT exogenous addition, blocked APO866-killing effects. Thus, this study places non-canonical autophagy as a critical 
first cellular answer to APO866, that is necessary to drive different haematological cancer cell lines to apoptotic cell death.

Burkitt Lymphoma (BL): In a model of MYC-induced lymphoma, Amaravadi et al. have shown in 2007 that combining alkylating chemotherapy with autophagy inhibition (using Chloroquine or shRNA targeting ATG5) enhanced cell death and tumour regression [196]. More recently, other demonstrations for a cytoprotective role of autophagy in BL have been brought by the work of Hart et al., linking accumulation of unfolded proteins in the endoplasmic reticulum (ER) and subsequent higher level of unfolded protein response (UPR) to cytoprotective autophagy activation and tumour cell survival [197]. Another study by Ni et al. demonstrated that treatment of BL cells with Gossypol (a natural BCL-2 inhibitor) induced reactive oxygen species (ROS) production and translocation of high mobility group box 1 (HMGB1) from the nucleus to the cytoplasm, which resulted in the activation of protective autophagy [198]. Finally, Zeng et al. reported in 2013 that recombinant human arginase (rhArg) treatment in Daudi and Raji cells induced proliferation arrest, apoptosis and cytoprotective autophagy. They further demonstrated that combining rhArg treatment with pharmacological or molecular autophagy inhibitors resulted in increased PARP cleavage and higher percentage of apoptotic cells [199]. Recently, Métayer et al. and Fan et al. reported the cytoprotective function of autophagy in asparaginase-treated (and not arginase-treated) Burkitt lymphoma cells [200] and in Vismodegib (an inhibitor of Hedgehog signalling pathway)-treated BL cells [201], respectively. Pujals et al. reported also that the resistance to Nutlin-3 (a p53 pathway activator) induced apoptosis, in EBV-positive BL with a latency III phenotype, involved the activation of autophagy and could be overcome by addition of Chloroquine [202].

Fan J. et al. reported in 2013 that treatment with a chimeric anti-human HLA-DR monoclonal antibody (chLym-1) induced autophagy (as evidenced by LC3 turnover assay, puncta formation and SQSMT1/p62 degradation) and that it constituted as a prerequisite to drive cells towards cell death. Indeed, the pharmacological (3-Methyladenine, Ammonium Chloride) or molecular (siRNA targeting Atg5) inhibition of autophagy suppressed the cytotoxic effects (growth inhibition, caspase-dependent apoptosis, antibody dependent cell death (ADCC) and complement-dependent cytotoxicity (CDC)) of chLym-1. Therefore, this study highlighted the potential benefit of chLym-1 combination with autophagy inducers in B-NHL cells [203].

Granato et al. reported that the treatment of BL cells by Quercetin (a bioflavonoid) resulted in $\mathrm{PI} 3 \mathrm{~K} / \mathrm{Akt} / \mathrm{mTOR}$ signalling inhibition and autophagy induction, which contributed to mutant c-Myc reduction. Thus, by stimulating the degradative function of autophagy, Quercetin induced a strong cytotoxic effect against Burkitt's lymphoma [204].

$\mathrm{Li}$ et al. reported recently that autophagy cell death occurred upon arsenic trioxide (As2O3) treatment. The 3-Methyladenine compound was found to reverse BECN1 and BCL-2 expression upand down-regulation, respectively, which resulted in an increase in cell viability through inhibition of autophagy cell death and apoptosis [205]. In another study, Dong et al. have reported in 2013 that the combination of the histone deacetylase inhibitor valproic acid (VPA) with mTOR inhibitor (Temsirolimus) synergistically inhibited BL cell growth in a murine xenografted model, through the activation of autophagic cell death [206]. Along the same line, a recent work by Ono et al. reported the potent action of rapamycin in inducing autophagic cell death in murine subcutaneously xenografted BL cells. Of note, they highlighted the successful specific delivery of liposome-encapsulated rapamycin, through their conjugation with anti-CD19 antibodies [207]. Finally, Turzanski et al. described the occurrence of autophagic cell death in BL cells owing to rituximab treatment [208].

Multiple Myeloma (MM): Recently, the role of autophagy in MM development and drugs resistance was investigated (for a review: [209]). The initial work of Hoang et al. demonstrated that autophagy blockade (using Chloroquine or 3-Methyladenine treatment) resulted in MM cells death, thus suggesting the pro-survival role of autophagy under basal conditions [138].

A study of Pan et al. in 2011 demonstrated the cytoprotective role of autophagy following DNA-damaging chemotherapy [210]. Indeed, the authors found that Melphalan and Doxorubicin 
induced autophagy in different MM cell lines, as evidenced by autophagosome accumulation upon electron microscopy quantification and LC3 turnover assay. Furthermore, autophagy inhibition, through the use of pharmacological inhibitors (3-Methyladenine, Hydroxychloroquine) or shRNA targeting BECN1 or ATG5 resulted in a significant improvement of the anti-myeloma activity of the chemotherapeutic treatment, both in vitro (increased apoptosis cell death) and in vivo (xenografted tumour growth prevention through apoptosis induction). Along the same line, HMGB1 knockdown in MM cells or in mice led to autophagy inhibition, which was associated with the potentiation of the dexamethasone chemotherapeutic effects, that is, increased apoptosis in vitro and reduced tumour burden in vivo [211].

Another study by Chen et al. in 2014 reported a cytoprotective function of autophagy in MM cells submitted to Bortezomib treatment [212]. In this setting, the authors further demonstrated that the combination of HDAC inhibitors and BH3-mimetics (ABT-737) resulted in an increase in BIM protein levels, which in turn, directly interacted with BECN1 and blocked the induction of autophagy. Thus, the authors conclude that targeting BIM in MM cells, by disabling cytoprotective autophagy, could overcome acquired Bortezomib resistance [212]. Other studies demonstrated the cytoprotective role of autophagy. The HDAC6 genetic knockout or the use of the HDAC6 inhibitor C1A in MM cells were found to induce cell death by blocking the autophagy degradation pathway of malformed proteins [213]. Similarly, Tigecycline (a glycylcycline antibiotic) induced cytoprotective autophagy in MM cell lines and its combined use with chloroquine was found to synergistically impair the tumour growth in a xenograft model of MM [214]. Elaiophylin, a macrolide antibiotic extracted from Streptomycin melanosporus, is a potent autophagy inhibitor [215]. In p53 mutant MM cells, Elaiphylin demonstrated an anti-myeloma activity in vitro and in vivo. Furthermore, Metformin targets GRP78 (glucose-regulated protein 78)-dependent autophagy in MM cells and potentiate the effect of Bortezomib on tumour regression with a significant survival benefit [216]. Carfilzomib is a second-generation proteasome inhibitor that shows a significant decrease in cell viability when combined with Chloroquine [217]. Furthermore, Chloroquine treatment can overcome the carfilzomib resistance in vitro [218]. In this context of resistance to proteasome inhibitors, Lu et al. found that Profilin1 (PFN1, a cytoskeleton protein) could bind to the BECN1 complex, to promote autophagy and to induce Bortezomib resistance in MM [219]. Zhang et al. found that ClC5, a member of the chloride channel family, promoted survival autophagy and chemoresistance in Bortezomib-treated MM cells [220]. In another study, the chemoresistance to Mephalan was found to be associated with an increased autophagy in MM cells. Mechanistically, the authors described that the high expression of the long non-coding RNA Linc00515 and the subsequent direct inhibition of miR-140-5p resulted in the upregulation of ATG14 levels and autophagy activation [221].

The work of Milan et al. identified SQSMT1/p62 as a novel specific anti-myeloma target, conferring resistance to Bortezomib [222]. Indeed, the authors found that proteasome inhibition not only induced increased SQSMT1/p62 expression levels but also facilitated its interaction with ubiquitinated proteins for subsequent autophagic degradation. Therefore, the lentiviral-mediated depletion in SQSMT1/p62 was found to increase cell sensitivity to proteasome inhibition. The authors concluded that the detection of SQSMT1/p62 aggregates at diagnosis could represent a major prognostic factor for MM patient's intrinsic susceptibility to proteasome inhibitors.

In plasma cells physiopathology, Lamy et al. proposed recently that autophagy might play an ambivalent role, that is, switching from cytoprotective or cytotoxic functions depending on caspase-10 activity. The authors found that caspase-10 inactivation (using Q-AEVD-OPH or shRNA targeting caspase-10) led to the stabilization of the BCLAF1/BCL-2 complex and the unleashed activation of BECN1, responsible for the autophagy process over-activation, culminating in autophagic cell death [140]. Indeed, the molecular inhibition of BECN1 and ATG5, through targeted siRNA, protected the cells against the autophagic cell death induced by caspase-10 inhibition.

Similarly, the work of Ma et al. pointed out the efficiency of combined chemotherapy (Dexamethasome) and proteasome inhibition (PS-341/Bortezomib) in multiple myeloma cell lines [129]. 
In this setting, one can hypothesize that survival autophagy was activated following proteasome inhibition, as an alternative way to deal with misfolded protein aggregates and that the combination with dexamethasone, by pushing toward excessive autophagy, induced a switch from cytoprotective to cytotoxic autophagy. In 2008, another molecule, called compound A (CpdA), was described by Chen et al. to stabilize p27 and induce caspase-independent cell death by activation of autophagy. Importantly, this drug overcome resistance to chemotherapy as well as to proteasome inhibitor in MM models, again strongly suggesting that killing of cells occurred through excessive CpdA-mediated autophagy activation [223]. Recently, Betulinic acid (BetA) was found to induce either apoptosis or autophagic cell death in MM cells, depending on the protein phosphatase 2A (PP2A) partner. Indeed, the authors found that under normal conditions, BetA induces caspase- 3 activation, cleavage of PP2A, inactivation of Akt and subsequent apoptosis. However, under conditions where apoptosis was blocked, the authors found that PP2A interacts with DAPK to induce autophagic cell death in BetA treated cells [141]. Another study reported that the activation of the endoplasmic reticulum stress, by using the drug Tunicamycin, induced autophagy and apoptosis in MM cells, thereby inhibiting proliferation and chemotherapy resistance [224].

Altogether, these numerous studies highlight autophagy as a promising therapeutic target in MM $[225,226]$.

Primary Effusion Lymphoma (PEL): In 2011, Sommermann et al. described that the treatment of B-NHL cells (including PEL but also DLBCL and lymphoblastoid cell lines) with chemical an NF-KB inhibitor induced cytoprotective autophagy to overcome the GLUT1 transporter sequestration into the cytoplasm and subsequent leading to a defect in glucose uptake and availability. The authors found indeed that the combination of NF-kB inhibitors with the pharmacological inhibition of autophagy, using Chloroquine and 3-Methyladenine, drove lymphoma cells to metabolic crisis and cell death [227]. In line with these data, Granato et al. reported that autophagy activity in PEL cells is mainly pro-survival and inhibits anti-proliferative effects of proteasome inhibitors [228]. More recently, the same group demonstrated that Quercetin, a flavonoid described as a PI3K/AKT/mTOR and STAT3 inhibitor, induces apoptosis and autophagy in PEL cells. Its combination with autophagy inhibitor (Bafilomycin A or siBECN1) was found to improve cell death in these tumour cells [229].

Anaplastic Large Cell Lymphoma (ALCL), ALK (Anaplastic Lymphoma Kinase) positive: Regarding the role of autophagy in ALK+ALCL therapy, Mitou et al. demonstrated that Crizotinib (the first ALK tyrosine kinase inhibitor (TKI)) treatment induced cytoprotective autophagy and that combining ALK inhibition with autophagy pharmacological or molecular inhibition improved the TKI drug efficiency [158]. In a follow-up study, Torossian et al. further found that combining ALK inactivation and BCL-2 molecular depletion resulted in the potentiation of autophagy and increased cell death (Torossian et al., manuscript in press [230]).

Follicular lymphoma $(F L)$ : Understanding the role of autophagy in FL therapies is at its premise. So far, the work of Brem et al. described that autophagy could be activated as an alternative cell death program upon BH3-mimetic treatment (Obatoclax) in Rituximab (RTX)-resistant cell lines [231]. Similarly, Leseux et al. demonstrated in 2008 that RTX induced mTOR inactivation in FL cells and further showed that the combination of RTX with rapamycin increased the anti-leukemic effect of the drugs, strongly suggesting that enhanced autophagy may trigger FL cell death [232].

\subsubsection{Acute Lymphoid Leukaemia}

In various haematological cell lines (including ALL, CLL and multiple myeloma cell lines), Laane et al. demonstrated in 2009 [233,234] that Dexamethasone treatment (a member of the glucocorticoide (GC) class of hormones) induced autophagy first (as evidenced by LC3 turnover assay and puncta formation), which was mandatory for the subsequent cell death by apoptosis. Indeed, autophagy inhibition through siRNA targeting BECN1 or through type III phosphatidylinositol 3-kinase (PI3KIII) complex chemical inhibition (using LY294002 and 3-Methyladenine) led to the inhibition of apoptosis. Along the same line, Polak et al. recently showed that the MEK inhibitor Selumetinib enhanced 
Dexamethasone toxicity in GC-resistant B-ALL cells through the stimulation of autophagy [235]. Different compounds have been found to induce autophagic cell death in B- and T-ALL. This is the case for Idarubicin (a chemotherapeutic drug (anthracycline)) [236] and for the mTORC1 inhibitor (Everolimus), both of which were found to induce cytotoxic autophagy [237], through the enhanced expression of BECN1 [238].

Back in 1997, Jia et al. first reported that TNF $\alpha$-mediated apoptosis in T-ALL was abrogated upon autophagy inhibition, pointing to an interplay between the two cell death process [239]. The treatment of ALL cell lines with APO866 (an inhibitor of nicotinamide phosphoribosyltransferase (NAMPT), a key enzyme in nicotinamide adenine dinucleotide (NAD) biosynthesis) was found to induce autophagy as a prerequisite for apoptotic cell death [194]. In line with these findings, Jiang et al. demonstrated recently that autophagy inhibition decreased the apoptotic rate of T-ALL Jurkat cells submitted to selenite treatment [240]. Two other studies demonstrated that glucocorticoide (GC)-induced apoptotic cell death involved the initial activation of autophagy. Of note, resistance to GC occurs in $10 \%$ of GC-treated B-ALL [241] and mainly involves a deficiency in apoptosis. Thus, treatment with the BCL-2 inhibitor Obatoclax resulted in the resensitization to drug-induced apoptosis and was found to trigger autophagic cell death [242]. Indeed, further studies showed that Obatoclax was able to activate three types of cell death, that is, apoptosis, autophagy and necroptosis in infant ALL [243]. In this context, Bonapace et al. found that autophagy-dependent necroptosis allowed to overcome GC resistance in T-ALL [244]. Finally, a recent gene expression profiling study in GC sensitive and resistant paediatric patients with B-ALL revealed that an altered expression of autophagy-related genes (converging towards autophagy inhibition) might contribute to the resistance phenotype [245].

As in other diseases, autophagy can also promote survival upon therapy. The work of Wallington-Beddoe et al. demonstrated in 2011 that the immunosuppressive FTY720 compound induced a caspase-independent cell death and a concomitant cytoprotective autophagy in B-ALL cells [246]. This synthetic sphingosine analogue has been described as an autophagy inhibitor in mantle cell lymphoma, highlighting the fact that drugs might have diverse effects on different cells [190]. The Akt inhibitor Triciribine was found to induce cytoprotective autophagy since Chloroquine co-treatment increased its cytotoxic effects [247]. More recently, the impairment of NOTCH1-controlled glutaminolysis (through the inhibition of NOTCH1), combined with the inhibition of the activated cytoprotective autophagy was found to have a synergistic anti-leukemic effect in T-ALL [248]. L-asparaginase (L-asp) is one of the mostly used drug for childhood ALL therapy. Poor response to this therapy has been linked to increased risk of relapse and therapy failures $[249,250]$. L-asp induces mitochondrial injury together with a cytoprotective autophagy to remove damaged mitochondria. Inhibiting autophagy with Chloroquine improve the treatment responses both in vitro and in vivo under these conditions [251].

\section{Autophagy and Myeloid Tumours}

\subsection{Aberrant Autophagy in Myeloid Dysplastic Syndromes and Myeloid Leukaemia}

\subsubsection{Myelodysplastic Syndrome (MDS)}

Myelodysplasic Syndrome (MDS) defines a heterogeneous group of hematopoietic diseases [252], divided in five main subgroups in 1982 that is, Refractory Anaemia (RA), Refractory Anaemia with Ring Sideroblasts (RARS), Refractory Anaemia with Excess of Blasts (RAEB), RAEB in transformation (RAEB-t) and Chronic Myelomonocytic Leukaemia (CMML). These pathologies are characterized by bone marrow cells morphology and abnormal cell numbers, peripheral blood cytopenias and propensity for Acute Myeloid Leukaemia (AML) progression in one third of the cases. MDS are clonal diseases, originated from hematopoietic stem cells [253,254], which acquired and accumulated diverse genetic alterations, mainly the chromosomal deletion $(\operatorname{del}(5 q))$ and mutations in genes affecting epigenetic control, transcription, RNA splicing or signal transduction pathways [255]. MDS occurs predominantly in the elderly and can be cured by allogeneic hematopoietic cell transplantation 
(AHCT) [256]. However, only few patients could benefit from this therapeutic strategy because of their advanced age and because of significant comorbidities and mortality associated with this procedure. According to the type of MDS and to the risk stratification, different therapies have emerged during the last two decades. It includes Erythropoiesis-Stimulating Agents (ESA), Hypomethylating Agents (HMA) such as Azanucleosides, Lenalidomide, Immunosuppressive Therapy (IT) or Iron Chelation Therapy (ICT) [257]. In this framework, several recent studies and one clinical trial highlight the potential of autophagy modulation in the treatment of MDS.

Several studies tried to decipher the role of autophagy in MDS development. Interestingly, increased expression of ATG2B and GSKIP due to germline copy number variation, predispose to several myeloid malignancies such as myeloproliferative neoplasm [258]. On the other hand, Park et al. demonstrated that MDS patients harbouring the mutation U2AF35(S35F) have increased ATG7 pre-mRNA levels that undergo aberrant distal cleavage at polyadenylation site [259]. This results in a decreased of both, ATG7 expression and autophagic activity sensitizing cells to transformation. In line with this data, nucleated red blood cells of high-risk MDS patients have lower LC3B levels and more defective mitochondria. Furthermore, LC3B levels correlated with haemoglobin levels [260]. In addition, ATG3 is expressed at lower level in MDS patients compared to healthy individuals. Furthermore overexpression of ATG3, in the SKM-1 MDS cell line induces an increase of autophagy activity and a caspase dependent cell death at steady state [261].

\subsubsection{Acute Myeloid Leukaemia}

Acute Myeloid Leukaemia (AML) is the most common type (80\%) of leukaemia in adults and mainly occurs in the elderly. AML is characterized by an arrest in myeloid differentiation and an aberrant cell survival/proliferation of leukaemia blasts with high clinical heterogeneity between individuals. The heterogeneity of this disease renders the treatment a real challenge in the clinic [262] with the exception of acute promyeloicytic leukaemia (APL) harbouring the chromosomal translocation $t(15 ; 17)$ encoding for the oncogenic fusion protein PML-RARA. Although the World Health Organization recently published a new and more precise classification of AML subtypes [263], very little progress has been made in terms of treatment. According to the Swiss national institute for cancer epidemiology research, the relative cumulative five year survival after AML diagnosis improved modestly between 2001-2007 and 2008-2013 from 19.2\% to 23.3\% in Switzerland [264]. The median age of AML patients is about 70 years [265] and with the increasing number of elderly people in wealthy countries, the prevalence of AML is expected to increase. Therefore, improvements in therapy are urgently needed.

A body of evidence indicates that primary AML blasts show low autophagy gene levels compared to nonleukemic or differentiation undergoing AML cells [266,267]. In the same vein, the autophagy receptor SQSMT1/p62 was shown to be upregulated during the neutrophil differentiation in APL cells. Accordingly, it was reported that miR-17, -20, -93 and -106, which target SQSMT1/p62, are expressed at higher levels in mouse and human hematopoietic blast cells than in neutrophils [268]. It is assumed that the upregulation of SQSMT1/p62 prevents the accumulation of ubiquitinated protein aggregates during terminal differentiation of APL cells and operates, as a pro-survival cellular mechanism in this context $[269,270]$. Recent evidence also demonstrated that the SQSMT1/p62 is essential for cell growth and the maintenance of mitochondrial integrity of murine myeloid leukaemia. Indeed, loss of SQSMT1/p62 has been shown to impair leukaemia development and mitophagy in this leukaemia type [271].

Several publications support the idea that the role of autophagy in leukaemia development varies depending on the oncogene that can affect the progression in the disease. The RET proto-oncogene is a receptor tyrosine kinase identified recently as an essential kinase in AML development [272]. Interestingly, RET activated pathways lead to a reduction of autophagy and stabilization of leukemogenic drivers such as mutant FLT3. Furthermore, inhibition of RET leads to FLT3 depletion via autophagy. Interestingly, proteasome inhibitors promote FLT3-ITD degradation through autophagy [273]. Conversely, inhibition of FLT3-ITD mutant in AML cells 
impairs autophagy-dependent proliferation in vitro and in vivo, indicating that FLT3-ITD supports a high level of basal autophagy. This FLT3-ITD dependent autophagy relies on the ATF4 transcription factor expression [274]. In AML cells with mutant NPM1, PML is stabilized within the cytoplasm. PML cytoplasmic localization leads to phosphorylation of AKT that subsequently activates a pro-survival autophagy [275].

In a MLL-ENL mouse model, inhibition of autophagy via knockout of Atg7 resulted in a modest increase of leukaemia survival free of mice together with a decrease in leukaemia initiating cells (LICs). MLL-ENL $A t g 7^{-/-}$LICs demonstrated an increased ROS production, linked to an increase in mitochondria activity and cell death. Accordingly, MLL-ENL $A \operatorname{tg} 7^{-/-}$blasts in the peripheral blood are decreased due to enhanced apoptosis [276]. Surprisingly, Watson et al. demonstrated that in MLL-ENL autophagy inhibition by either knocking out ATG7 or ATG5 leads to more aggressive leukaemia in vivo. Furthermore, they demonstrated that MLL-ENL cells with decreased autophagy activity allow for abnormal mitochondria activity, proliferation and a glycolytic shift [267]. In an AML1-ETO AML mouse model, autophagy inhibits self-renewal potential of LICs [277].

Mll-Af9 (MA9) AML cells show high autophagic flux compared to normal bone marrow but interestingly disruption of either Rb1cc1 or Atg 5 does not affect growth or survival of MA9-AML cells in both in vitro and in vivo [278]. Indeed, Liu et al. demonstrated that autophagy activity is needed for the development of the disease but is dispensable for the maintenance of leukaemia in this particular subtype [279].

The H2.0-like homeobox transcription factor (HLX), which is overexpressed in AML is another factor involved in regulating hematopoietic differentiation. It has been reported that HLX upregulation resulted in AMPK activation and increased viability of AML cells possibly via autophagy activation [280].

Together, AML is a highly heterogeneous disease and therefore it is not surprising that autophagy act as either a tumour promotion or suppression mechanism depending on the AML subtype.

\subsubsection{Chronic Myeloid Leukaemia}

Chronic myeloid leukaemia (CML) represents $15 \%$ of all leukaemias and mainly occurs in adults (median age at diagnosis: 66). CML is characterized by the translocation $\mathrm{t}(9 ; 22)(\mathrm{q} 34 ; \mathrm{q} 11)$ resulting in the expression of the BCR-ABL fusion protein, which harbours an unrestrained tyrosine kinase activity. It presents first as an indolent disease, also called the chronic phase (CP), which can last for many years and corresponds to the expansion of myeloid cell progenitors from leukemic stem cells. The loss of terminal differentiation leads to a more aggressive advanced phase (AP), characterized by the accumulation of either myeloid blasts, pre-B lymphoma blasts or T cells blasts in $65 \%, 35 \%$ and $5 \%$ of the cases, respectively. This evolution to "blast crisis" happens through the acquisition of additional chromosomal abnormalities including p53 mutations. How BCR-ABL expression leads to leukemogenesis has been widely investigated and many signalling pathways downstream of the oncogenic tyrosine kinase have been found to be dysregulated. Since 2001, the standard front line therapy for patients with newly diagnosed CML is ABL tyrosine kinase inhibitor (Imatinib) treatment. The remarkable success of Imatinib treatment subsequently led to the new area of "targeted therapy" for many other cancer types with a well-defined molecular abnormality. This treatment efficiently controls disease progression unless mutations in the BCR-ABL oncogene (in $40 \%$ of the cases) or other resistance mechanisms, for example, BCR-ABL amplification or increased drug efflux, occur. These resistances occur in $15 \%$ of the patients within the first 5 years of the treatment and patients are either treated by second generation TKI or by allogenic hematopoietic cell transplantation. For patients who evolved towards a blast crisis, the prognosis remains poor. Thus, while the current ITK therapy successfully allows to control CML progression for the majority of the patients $(85 \%)$, future therapeutic strategies are currently investigated to eradicate the disease, notably by targeting the leukemic stem cells, which are known to be insensitive to the TKI treatment [281]. In this framework, the role of autophagy has been found controversial, according to the drug treatment and to the downstream 
activated signalling pathway. Of note, an autophagy-mediated degradation of the fusion BCR-ABL oncoprotein has also been reported, thus highlighting that a threshold of autophagy induction along with BCR-ABL expression levels might control leukemic cell fate upon treatment [282].

It has been further demonstrated that BCR-ABL1 induces autophagy in a MAPK15-dependent manner which potentially leads to cell transformation [283]. On the other hand Sheng et al. described that BCR-ABL inhibits autophagy in a ATF5-dependent manner but only in transformed cells [284].

Interestingly, Lys05, a second generation of autophagy inhibitor, was shown to reduce CML leukaemia stem cell quiescence and to induce maturation of CML cells [285]. Moreover, Lys05 or PIK-III (an inhibitor of the PtIns3P class III) when combined with Tyrosine kinase inhibitor selectively reduced the number of primary CML LSCs suggesting the relevance of this drug combination strategy for killing cancer stem cells in CML patients [285].

Using a culture strategy by keeping cells first at low oxygen concentrations followed by non-restricted $\mathrm{O} 2$ supply, Ianniciello et al. demonstrated that K562 CML cells or primary CML CD34+ cells needed autophagy for commitment but not for proliferation [286]. Furthermore, BIM1 expression was proposed to support the progression of CML towards acute phases. Indeed, BIM1 inhibition triggers CCNG2 expression and a drop in clonogenicity linked to a decrease in tumour-suppressive autophagy response [287].

\subsection{Autophagy-Based Treatment Strategies in Myeloid Dysplastic Syndromes and Myeloid Leukaemia}

\subsubsection{Myelodysplastic Syndrome (MDS)}

A study performed on SKM1 myeloid cells has shown that their resistance to 5-Azacytidine treatment could be circumvented through autophagy activation [288]. Of note, these results account for the basis of a clinical trial using autophagy activators in the treatment of high risk MDS and AML (Clinical trial number: NCT 01210274, Table 1). Accordingly, another recent study performed by the same group on primary CMML myeloid cells, demonstrated that autophagy activation, through the stimulation of the purinergic receptor P2RY6 and its downstream CAMKK2-PRKAA1-ULK1 signalling pathway, was mandatory to restore the normal differentiation of monocytes to macrophages and thus, could represent a new promising therapy for this pathology [81]. Interestingly, in SKM-1 MDS cells, FOXO3A has been described as a positive regulator of autophagy. Silencing FOXO3A leads to a reduction of autophagy and promotes differentiation induced by decitabine [289]. Dubois et al. reported recently that LAMP2 deficiency (and subsequent major defects in Chaperone Mediated Autophagy (CMA)) in Azacytidine-resistant MDS cells resulted in their hypersensitivity to lysosomes and (macro)autophagy inhibitors. Thus, targeting macroautophagy in CMA deficient LAMP2 ${ }^{\text {low }}$ MDS/AML patients appears as a new therapeutic option [290].

Autophagy precedes apoptotic cell death in $\mathrm{CD}^{4} 4^{+}$cells isolated from high-risk MDS and in MDS cell lines following nutrient deprivation and inhibition of the NF- $\mathrm{KB}$-activating IK- $\mathrm{kB}$ kinase complex using the BAY11-7082 compound. In this framework, it has been shown that a bioenergic failure drives the activation of autophagy and then apoptosis, as assessed by classical and typical cellular features. However, the authors found that cell death occurred even in the context of autophagy or apoptosis blockade, thus highlighting the high plasticity of MDS cells in their cell death modalities [291]. Bortezomib (Velcade) is a proteasome inhibitor widely used to treat cancers including MDS and AML. Interestingly, Fang et al. demonstrated that Bortezomib induced degradation of TRAF6 via autophagy leading to cell death while inhibiting autophagy using 3-Methyladenine leads to increased survival of MDS and AML cells [292]. 
Table 1. List of clinical trial involving autophagy modulation in hematopoietic cancers.

\begin{tabular}{|c|c|c|c|c|}
\hline \multirow{2}{*}{ Haematological Malignancies } & \multirow{2}{*}{\multicolumn{2}{|c|}{$\begin{array}{c}\text { Therapeutic Modulation of Autophagy Single Drug } \\
\text { or Combination }\end{array}$}} & \multicolumn{2}{|l|}{ Clinical Trials } \\
\hline & & & Number & Phase \\
\hline Chronic lymphocytic leukaemia & \multirow{6}{*}{ 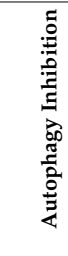 } & Hydroxychloroquine (HCQ) & NCT00771056 & II \\
\hline \multirow{2}{*}{ Multiple myeloma } & & HCQ + Bortezomib & NCT00568880 & $\mathrm{I} / \mathrm{II}$ \\
\hline & & $\begin{array}{l}\text { HCQ + Cyclophosphamide + } \\
\text { Dexamethasone + Rapamycin }\end{array}$ & NCT01689987 & I \\
\hline Lymphoma & & Vinblastine & NCT00059839 & III \\
\hline Chronic myeloid leukaemia & & HCQ + Imatinib & NCT01227135 & II \\
\hline Acute myelogenous leukaemia & & HCQ + Mitoxantone + Etoposide & NCT02631252 & I \\
\hline Chronic myeloid leukaemia & \multirow{27}{*}{ 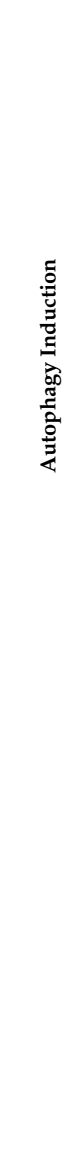 } & Everolimus (RAD001, mTORC1 inhibitor) & NCT01188889 & $\mathrm{I} / \mathrm{II}$ \\
\hline \multirow{3}{*}{ Chronic lymphocytic leukaemia } & & Everolimus + Alemtuzumab & NCT00935792 & $\mathrm{I} / \mathrm{II}$ \\
\hline & & CAL-101 (PI3Kd inhibitor) & NCT01539512 & III \\
\hline & & Perfosine & NCT00873457 & II \\
\hline Relapsed follicular or mantle cell lymphoma & & Temsirolimus (mTORC1 inhibitor) & NCT01078142 & I \\
\hline Multiple myeloma & & $\begin{array}{l}\text { Everolimus + Panobinostat } \\
\text { (HDAC inhibitor) }\end{array}$ & NCT00918333 & $\mathrm{I} / \mathrm{II}$ \\
\hline Multiple myeloma, Lymphoma & & $\begin{array}{l}\text { Everolimus + Sorafenib } \\
\text { (multikinase inhibitor) }\end{array}$ & NCT00474929 & $\mathrm{I} / \mathrm{II}$ \\
\hline Acute monoblastic leukaemia & & Lithium & NCT01820624 & I \\
\hline Advanced haematological malignancies & & Triciribine & NCT00642031 & I \\
\hline Myelodysplasic syndrome and & & Autophagy inducer + Azacitidine & NCT01210274 & Recruiting \\
\hline Acute myelogenous leukaemia & & & & \\
\hline \multirow{2}{*}{ Relapsed/Refractory NHL or HL } & & \multirow{2}{*}{ CAL-101 } & NCT01306643/NCT01393106 & \multirow{2}{*}{$\mathrm{I} / \mathrm{II}$} \\
\hline & & & NCT01282424 & \\
\hline \multirow{3}{*}{ Relapsed/Refractory NHL } & & \multirow{2}{*}{ CAL-101 + Rituximab +/ - Bendamustine } & NCT01088048/NCT01732913 & \multirow{2}{*}{ I } \\
\hline & & & NCT01732926 & \\
\hline & & CAL-101 + GS-9973 (Syk inhibitor) & NCT01796470 & II \\
\hline \multirow{2}{*}{ Lymphoma malignancies } & & IPI-145 (PI3Kd and PI3Kg inhibitor) & NCT01476657 & I \\
\hline & & $\begin{array}{l}\text { CC-223 (dual mTORC1 and } \\
\text { mTORC2 inhibitor) }\end{array}$ & NCT01177397 & $\mathrm{I} / \mathrm{II}$ \\
\hline \multirow{5}{*}{$\begin{array}{l}\text { Relapsed/Refractory/Newly } \\
\text { diagnosed lymphoma }\end{array}$} & & \multirow{5}{*}{$\begin{array}{l}\text { Everolimus in combination therapies }(+/- \\
\text { Antibodies }+/- \text { TKIs }+/- \text { Chemotherapy) }\end{array}$} & NCT00869999/NCT01334502 & \multirow{5}{*}{$\mathrm{I} / \mathrm{II}$} \\
\hline & & & NCT01198665/NCT01665768 & \\
\hline & & & NCT01854606/NCT01341834 & \\
\hline & & & NCT01075321/NCT01567475 & \\
\hline & & & NCT00352443/NCT01453504 & \\
\hline \multirow{4}{*}{ Relapsed/Refractory lymphoma } & & Everolimus & NCT00436618 & II \\
\hline & & Everolimus + Panobinostat & NCT00962507/NCT00978432 & $\mathrm{I} / \mathrm{II}$ \\
\hline & & Ridaforolimus (mTORC1 inhibitor) & $\begin{array}{c}\text { NCT00060632/NCT00060645 } \\
\text { NCT00086125 }\end{array}$ & $\mathrm{I} / \mathrm{II}$ \\
\hline & & $\begin{array}{l}\text { Ridaforolimus + Vorinostat } \\
\text { (HDAC inhibitor) }\end{array}$ & NCT 01169532 & $\mathrm{I} / \mathrm{II}$ \\
\hline
\end{tabular}

\subsubsection{Acute Myeloid Leukaemia}

Standard treatment is based on chemotherapy, which successfully reduces the bulk of leukemic cells but unfortunately spares the malignant stem or progenitor cells, therefore leading to a high propensity for leukaemia relapses. Many studies have shown the induction of autophagy in AML cells exposed to a variety of new drugs. In accordance with the known dual role of autophagy upon anti-cancer therapies in solid tumours, both pro-survival and pro-death functions have been attributed to autophagy in therapeutically challenged AML [293]. Furthermore, in a few studies activation of autophagy primed AML cells towards other forms of cell death [291]. Finally, a switch from cytotoxic to cytoprotective autophagy has been shown to occur in the same AML cell line, depending on the concentration of AZD8055, a specific mTOR kinase inhibitor [294].

Conventional treatment of AML cells with chemotherapy can induce cytoprotective autophagy through HMGB1 release. Indeed, the use of neutralizing antibodies potentiated the chemotherapy-induced cytotoxicity [295]. Autophagy serves a critical role in protecting AML cells from Cytarabine and in the development of Cytarabine resistance [296]. Targeting autophagy permits to overcome Cytarabine resistance not only in AML cells but also in co-culture of AML cells with 
marrow-derived mesenchymal stromal cells [297]. Furthermore, Cytarabine treatment induces autophagy in leukaemia-initiating cell and autophagy inhibition sensitizes cells to the anti-leukemic effect of Cytarabine supporting again to the contribution of autophagy to Cytarabine resistance [276]. However, low dose of Cytarabine treatment promotes cytotoxic autophagy in U937 AML cells highlighting that the effect of autophagy on cell demise depends at least in part on the dose of anti-cancer therapy used [298].

Several groups have demonstrated that pro-survival autophagy is activated in AML cells submitted to dual mTORC1/mTORC2 inhibitors [294,299]. Along the same line, it was found that inhibition of mTORC1, following L-asparaginase treatment in AML cells, resulted in cytoprotective autophagy [300].

Simonsen et al. also demonstrated that treatment with HDAC inhibitors induced cytoprotective autophagy in AML1-ETO-positive AML cells, at least in part through mTOR inactivation. Furthermore, the authors showed that inhibition of autophagy by either the concomitant use of 3-Methyadenine or Chloroquine or the molecular down-regulation of ATG7 resulted in increased apoptosis [301]. In the same vein, potent repression of autophagy through ATG7 downregulation was associated with mitochondrial homeostasis defects, ROS accumulation, DNA damage and apoptotic cell death in a specific subset of AML cells (Down syndrome) submitted to HDACi, further highlighting the cytoprotective function of autophagy in this context [302].

The combination of Obatoclax, an inhibitor of the anti-apoptotic proteins BCL-2, BCL-xL and Mcl-1 with Sorafenib (a multi-kinase inhibitor) was also shown to induce cytoprotective autophagy in AML cells. Indeed, the pharmacological inhibition of autophagy by using 3-Methyladenine, Chloroquine or Bafilomycin A1, strongly potentiated cell toxicity of the drug combination [303].

Early studies tended to associate the accumulation of autophagosomes in AML cells to the occurrence of cell death. This was the case in the HL60 AML cell line submitted to Morphinone [304] and to AML cells and primary cells from patients submitted to APO866 (a NAD biosynthesis inhibitor) [194,195]. More recently, Ristic et al. demonstrated the activation of an mTOR-dependent cytotoxic autophagy upon Idarubicin treatment [236]. Interestingly, the AMPK agonist GSK621 has been shown to promote autophagy concomitantly to mTOR activation, a process that leads to AML cell killing [305]. Arsenic trioxide treatment of AML cells was also shown to elicit autophagy cell death through a mechanism that is not fully understood [306].

In addition, autophagy is involved in the degradation of certain AML oncoproteins such as PML-RARA and FLT3-ITD [273,307] but not AML1-ETO [301]. These results demonstrate that autophagy can selectivity eliminate oncoproteins through mechanisms that warrant further investigation. All-trans retinoic acid (ATRA), a potent differentiation agent, has been reported to effectively promote clinical remission of APL when combined with anthracyclines or arsenic trioxide (ATO) [308]. Importantly, several groups showed activation of autophagy during ATRA-induced granulocytic differentiation of APL cells [307,309-312]. This response occurs through WIPI dependent and BECN1 independent mechanism and is associated with increased expression of GATE16, MAP1S, DRAM1, HMGB1 and SQSMT1/p62 [269,310,312-316]. ATRA treatment also induced selective degradation of ubiquitinated proteins through a SQSMT1/p62 dependent mechanism [269]. While molecular and pharmacological inhibition of autophagy attenuated granulocytic differentiation of APL cells, downregulation of BECN1 and SQSMT1/p62 expressions did not affect this process but rather promoted APL cell death. Autophagy was assumed to promote differentiation of APL cells through a mechanism that relies on PML-RARA degradation. Interestingly, recent studies have revealed that non-coding RNAs, that is, the microRNA (miR) miR125B1 and the long noncoding RNA (lncRNA) HOTAIRM1 could negatively or positively regulate the degradation of PML-RARA during the process of ATRA-mediated myeloid cell differentiation, respectively [317,318]. PML-RARA is also cleared upon arsenic trioxide treatment of APL through a mechanism that involves proteasomal and autophagic pathways [319]. The combination of ATRA with Dasatinib also promoted autophagy and the differentiation of leukemic cells [320]. Finally, Goussetis et al. demonstrated that APO 
treatment of non-APL cells resulted in autophagic cell death through the activation of the MEK/ERK pathway [306]. However, another study has shown that APO inhibited the autophagic flux [321]. Altogether, these studies point to the distinct roles of several autophagy-regulatory pathways in acute myeloid leukaemia cells demise.

\subsection{Chronic Myeloid Leukaemia}

Goussetis et al. first reported the autophagic degradation of the BCR-ABL oncoprotein in CML cells under arsenic trioxide (ATO) treatment in 2012 [282]. Elzinga et al. further confirmed that Imatinib treatment induced also the sequestration of the BCR-ABL oncoprotein in autophagosomes, allowing its subsequent degradation [322]. These results are important since they highlight for the first time that autophagy intensity and/or duration, within a drug treated leukemic cells, could control its fate, from survival to cell death, through the tight regulation of the driven oncogene expression levels.

Carew et al. reported that the treatment of different CML cell lines and primary CML cells expressing wild-type and Imatinib-resistant mutant forms of BCR-ABL, including T315I, with an histone deacetylase inhibitor (suberoylanilide hydroxamic acid (SAHA)) induced autophagy and that its inhibition (by using Chloroquine) potentiated the anti-neoplastic effects of SAHA [323]. Two years later, Bellodi et al. reported a study of noticeable clinical importance which showed that Imatinib treatment of CML cells induced cytoprotective autophagy and that the inhibition of autophagy, by using pharmacological (Chloroquine, Bafilomycin A1) or RNA interference of essential autophagy genes (ATG5, ATG7) potentiated the drug efficiency not only in CML blast crisis cell lines and CML primary cells but also in leukemic stem cells isolated from patients [324-326]. In line with these findings, Crowley et al. reported that pharmacological agents with inherent anti-autophagic activity improved the cytotoxicity of imatinib [327]. More recently, Zeng et al. found a synergistic effect when combining the inhibition of Hedgehog signalling, which is important for the malignant stem cell maintenance and the inhibition of autophagy [328]. Compounds such as Resveratrol, a natural phytoalexin isolated from grapes) and Acadesine (AICAR, 5-aminoimidazole-4-carboxyamide ribonucleoside, known to activate AMPK) were found to induce autophagic cell death in both sensitive or resistant CML cell lines to Imatinib, through AMPK activation and SQSMT1/p62 upregulation $[329,330]$ and through PKC activation [331], respectively. More recently, Tong et al. found that an oncolytic adenovirus expressing BECN1 was efficient in inducing autophagic cell death in different leukemic cell lines and primary leukemic blasts, along with Imatinib resistant cells [332].

\section{Conclusions}

While a lot of effort was put into understanding the role of autophagy in cell transformation and the benefit of autophagy-based treatment strategies, the function of autophagy remains ambiguous in hematopoietic cancers. Furthermore, in many settings autophagy has been shown to play a divergent role in the outcome of hematopoietic cancers, thus, caution should be taken when the modulation of autophagy is considered as a therapeutic strategy to improve the treatment of hematopoietic cancers. Several points have been discussed already to try to solve issues encountered in many different diseases where autophagy-based therapy might be an option [333]. Nevertheless, as shown in Table 1, modulating autophagy in hematopoietic cancer is attractive and may open new avenues for efficient treatment strategies.

In addition, autophagy can be either selective or non-selective and several examples highlight non-canonical autophagy regulation in some hematopoietic cancers. Understanding how the autophagy machinery is involved in healthy and malignant hematopoietic cells as well as identifying the role of specific autophagic cargos during transformation, maintenance and treatment response will help us to have better understanding the role of autophagy in haematopoiesis and to develop new targeted strategies to improve treatment of hematopoietic diseases. Furthermore, recently a study on Chloroquine demonstrated that unlike Bafilomycin A1, Chloroquine and Hydroxychloroquine leads to an accumulation of autophagosomes [334]. Additionally, Chloroquine alters the Golgi organization and 
causes the vacuolization of lysosomes. Therefore, pre-clinical and clinical studies that used Chloroquine as only autophagy inhibitor should be validated by using more specific autophagy modulators.

Funding: This work was supported by grants from Swiss Cancer Research (KFS-3409-02-2014 to M.P.T.) and the Werner and Hedy Berger-Janser Foundation of Cancer Research (to M.P.T.), the «Conseil Régional d'Aquitaine» and the «INCa-DGOS-Inserm 6046» (to M.D.-M.), the Bernese Cancer League, UniBE Initiator grant and Stiftung für Klinisch-Experimentelle Tumorforschung (to M.H.). This project has received funding from the European Union's Horizon 2020 research and innovative Programme under the Marie Sklodowska-Curie grant agreement No 675712 (S.G.).

Acknowledgments: The authors thank R. Chiarle (Boston Children Hospital, Boston, USA) for critical reading and C. Joffre (CRCT, Toulouse, France) and Sreoshee Rafiq (Institute of Pathology, Bern, Switzerland) for their corrections and inputs on the manuscript.

Conflicts of Interest: The authors declare no conflicts of interest.

\section{References}

1. Klionsky, D.J.; Codogno, P. The mechanism and physiological function of macroautophagy. J. Innate Immun. 2013, 5, 427-433. [CrossRef] [PubMed]

2. Kroemer, G.; Mariño, G.; Levine, B. Autophagy and the Integrated Stress Response. Mol. Cell 2010, 40, 280-293. [CrossRef] [PubMed]

3. Reggiori, F.; Komatsu, M.; Finley, K.; Simonsen, A. Autophagy: More Than a Nonselective Pathway. Int. J. Cell Biol. 2012, 2012, e219625. [CrossRef] [PubMed]

4. White, E.; Mehnert, J.M.; Chan, C.S. Autophagy, Metabolism, and Cancer. Clin. Cancer Res. 2015, 21, 5037-5046. [CrossRef] [PubMed]

5. Mizushima, N.; Komatsu, M. Autophagy: Renovation of cells and tissues. Cell 2011, 147, 728-741. [CrossRef] [PubMed]

6. Choi, A.M.K.; Ryter, S.W.; Levine, B. Autophagy in human health and disease. N. Engl. J. Med. 2013, 368, 651-662. [CrossRef] [PubMed]

7. Mizushima, N.; Yoshimori, T.; Ohsumi, Y. The Role of Atg Proteins in Autophagosome Formation. Annu. Rev. Cell Dev. Biol. 2011, 27, 107-132. [CrossRef]

8. Proikas-Cezanne, T.; Takacs, Z.; Dönnes, P.; Kohlbacher, O. WIPI proteins: Essential PtdIns3P effectors at the nascent autophagosome. J. Cell Sci. 2015, 128, 207-217. [CrossRef]

9. Khaminets, A.; Behl, C.; Dikic, I. Ubiquitin-Dependent and Independent Signals in Selective Autophagy. Trends Cell Biol. 2016, 26, 6-16. [CrossRef]

10. Johansen, T.; Lamark, T. Selective autophagy mediated by autophagic adapter proteins. Autophagy 2011, 7, 279-296. [CrossRef]

11. Mochida, K.; Oikawa, Y.; Kimura, Y.; Kirisako, H.; Hirano, H.; Ohsumi, Y.; Nakatogawa, H. Receptor-mediated selective autophagy degrades the endoplasmic reticulum and the nucleus. Nature 2015, 522, 359-362. [CrossRef] [PubMed]

12. Novak, I.; Kirkin, V.; McEwan, D.G.; Zhang, J.; Wild, P.; Rozenknop, A.; Rogov, V.; Löhr, F.; Popovic, D.; Occhipinti, A.; et al. Nix is a selective autophagy receptor for mitochondrial clearance. EMBO Rep. 2010, 11, 45-51. [CrossRef] [PubMed]

13. Cecconi, F.; Levine, B. The role of autophagy in mammalian development: Cell makeover rather than cell death. Dev. Cell 2008, 15, 344-357. [CrossRef]

14. Mizushima, N.; Levine, B.; Cuervo, A.M.; Klionsky, D.J. Autophagy fights disease through cellular self-digestion. Nature 2008, 451, 1069-1075. [CrossRef] [PubMed]

15. Chen, H.-Y.; White, E. Role of Autophagy in Cancer Prevention. Cancer Prev. Res. 2011, 4, 973-983. [CrossRef]

16. Strohecker, A.M.; White, E. Autophagy promotes BrafV600E-driven lung tumorigenesis by preserving mitochondrial metabolism. Autophagy 2014, 10, 384-385. [CrossRef]

17. Guo, J.Y.; White, E. Autophagy is required for mitochondrial function, lipid metabolism, growth, and fate of KRAS(G12D)-driven lung tumors. Autophagy 2013, 9, 1636-1638. [CrossRef]

18. Degenhardt, K.; Mathew, R.; Beaudoin, B.; Bray, K.; Anderson, D.; Chen, G.; Mukherjee, C.; Shi, Y.; Gélinas, C.; Fan, Y.; et al. Autophagy promotes tumor cell survival and restricts necrosis, inflammation, and tumorigenesis. Cancer Cell 2006, 10, 51-64. [CrossRef] 
19. Guo, J.Y.; Chen, H.-Y.; Mathew, R.; Fan, J.; Strohecker, A.M.; Karsli-Uzunbas, G.; Kamphorst, J.J.; Chen, G.; Lemons, J.M.S.; Karantza, V.; et al. Activated Ras requires autophagy to maintain oxidative metabolism and tumorigenesis. Genes Dev. 2011, 25, 460-470. [CrossRef]

20. Thorburn, A.; Thamm, D.H.; Gustafson, D.L. Autophagy and cancer therapy. Mol. Pharmacol. 2014, 85, 830-838. [CrossRef]

21. Orsini, M.; Morceau, F.; Dicato, M.; Diederich, M. Autophagy as a pharmacological target in hematopoiesis and hematological disorders. Biochem. Pharmacol. 2018, 152, 347-361. [CrossRef] [PubMed]

22. Doulatov, S.; Notta, F.; Laurenti, E.; Dick, J.E. Hematopoiesis: A human perspective. Cell Stem Cell 2012, 10, 120-136. [CrossRef] [PubMed]

23. Orkin, S.H.; Zon, L.I. Hematopoiesis: An evolving paradigm for stem cell biology. Cell 2008, 132, 631-644. [CrossRef] [PubMed]

24. Kohli, L.; Passegué, E. Surviving change: The metabolic journey of hematopoietic stem cells. Trends Cell Biol. 2014, 24, 479-487. [CrossRef] [PubMed]

25. Rossi, D.J.; Seita, J.; Czechowicz, A.; Bhattacharya, D.; Bryder, D.; Weissman, I.L. Hematopoietic stem cell quiescence attenuates DNA damage response and permits DNA damage accumulation during aging. Cell Cycle 2007, 6, 2371-2376. [CrossRef] [PubMed]

26. Ogawa, M. Differentiation and proliferation of hematopoietic stem cells. Blood 1993, 81, 2844-2853. [PubMed]

27. Van Zant, G.; Liang, Y. The role of stem cells in aging. Exp. Hematol. 2003, 31, 659-672. [CrossRef]

28. Morrison, S.J.; Wandycz, A.M.; Akashi, K.; Globerson, A.; Weissman, I.L. The aging of hematopoietic stem cells. Nat. Med. 1996, 2, 1011-1016. [CrossRef]

29. Sudo, K.; Ema, H.; Morita, Y.; Nakauchi, H. Age-associated characteristics of murine hematopoietic stem cells. J. Exp. Med. 2000, 192, 1273-1280. [CrossRef]

30. Rossi, D.J.; Bryder, D.; Zahn, J.M.; Ahlenius, H.; Sonu, R.; Wagers, A.J.; Weissman, I.L. Cell intrinsic alterations underlie hematopoietic stem cell aging. Proc. Natl. Acad. Sci. USA 2005, 102, 9194-9199. [CrossRef]

31. Chambers, S.M.; Shaw, C.A.; Gatza, C.; Fisk, C.J.; Donehower, L.A.; Goodell, M.A. Aging hematopoietic stem cells decline in function and exhibit epigenetic dysregulation. PLoS Biol. 2007, 5, e201. [CrossRef] [PubMed]

32. Mortensen, M.; Soilleux, E.J.; Djordjevic, G.; Tripp, R.; Lutteropp, M.; Sadighi-Akha, E.; Stranks, A.J.; Glanville, J.; Knight, S.; Jacobsen, S.-E.W.; et al. The autophagy protein Atg7 is essential for hematopoietic stem cell maintenance. J. Exp. Med. 2011, 208, 455-467. [CrossRef] [PubMed]

33. Liu, F.; Lee, J.Y.; Wei, H.; Tanabe, O.; Engel, J.D.; Morrison, S.J.; Guan, J.-L. FIP200 is required for the cell-autonomous maintenance of fetal hematopoietic stem cells. Blood 2010, 116, 4806-4814. [CrossRef] [PubMed]

34. Warr, M.R.; Binnewies, M.; Flach, J.; Reynaud, D.; Garg, T.; Malhotra, R.; Debnath, J.; Passegué, E. FOXO3A directs a protective autophagy program in haematopoietic stem cells. Nature 2013, 494, 323-327. [CrossRef] [PubMed]

35. Cao, Y.; Cai, J.; Zhang, S.; Yuan, N.; Fang, Y.; Wang, Z.; Li, X.; Cao, D.; Xu, F.; Lin, W.; et al. Autophagy Sustains Hematopoiesis Through Targeting Notch. Stem Cells Dev. 2015, 24, 2660-2673. [CrossRef] [PubMed]

36. Cao, Y.; Fang, Y.; Cai, J.; Li, X.; Xu, F.; Yuan, N.; Zhang, S.; Wang, J. ROS functions as an upstream trigger for autophagy to drive hematopoietic stem cell differentiation. Hematology 2016, 21, 613-618. [CrossRef] [PubMed]

37. Ho, T.T.; Warr, M.R.; Adelman, E.R.; Lansinger, O.M.; Flach, J.; Verovskaya, E.V.; Figueroa, M.E.; Passegué, E. Autophagy maintains the metabolism and function of young and old stem cells. Nature 2017, 543, 205-210. [CrossRef]

38. Cooper, M.D. The early history of B cells. Nat. Rev. Immunol. 2015, 15, 191-197. [CrossRef]

39. Gascoigne, N.R.J.; Rybakin, V.; Acuto, O.; Brzostek, J. TCR Signal Strength and T Cell Development. Annu. Rev. Cell Dev. Biol. 2016, 32, 327-348. [CrossRef]

40. Bhandoola, A.; von Boehmer, H.; Petrie, H.T.; Zúñiga-Pflücker, J.C. Commitment and developmental potential of extrathymic and intrathymic T cell precursors: Plenty to choose from. Immunity 2007, 26, 678-689. [CrossRef]

41. Pua, H.H.; Dzhagalov, I.; Chuck, M.; Mizushima, N.; He, Y.-W. A critical role for the autophagy gene Atg5 in T cell survival and proliferation. J. Exp. Med. 2007, 204, 25-31. [CrossRef] 
42. Stephenson, L.M.; Miller, B.C.; Ng, A.; Eisenberg, J.; Zhao, Z.; Cadwell, K.; Graham, D.B.; Mizushima, N.N.; Xavier, R.; Virgin, H.W.; et al. Identification of Atg5-dependent transcriptional changes and increases in mitochondrial mass in Atg5-deficient T lymphocytes. Autophagy 2009, 5, 625-635. [CrossRef] [PubMed]

43. Li, C.; Capan, E.; Zhao, Y.; Zhao, J.; Stolz, D.; Watkins, S.C.; Jin, S.; Lu, B. Autophagy is induced in CD4+ T cells and important for the growth factor-withdrawal cell death. J. Immunol. 2006, 177, 5163-5168. [CrossRef]

44. Paul, S.; Kashyap, A.K.; Jia, W.; He, Y.-W.; Schaefer, B.C. Selective autophagy of the adaptor protein Bcl10 modulates T cell receptor activation of NF-кB. Immunity 2012, 36, 947-958. [CrossRef] [PubMed]

45. Bell, B.D.; Leverrier, S.; Weist, B.M.; Newton, R.H.; Arechiga, A.F.; Luhrs, K.A.; Morrissette, N.S.; Walsh, C.M. FADD and caspase- 8 control the outcome of autophagic signaling in proliferating T cells. Proc. Natl. Acad. Sci. USA 2008, 105, 16677-16682. [CrossRef]

46. Lünemann, J.D.; Münz, C. Autophagy in CD4+ T-cell immunity and tolerance. Cell Death Differ. 2009, 16, 79-86. [CrossRef] [PubMed]

47. Rivera Vargas, T.; Cai, Z.; Shen, Y.; Dosset, M.; Benoit-Lizon, I.; Martin, T.; Roussey, A.; Flavell, R.A.; Ghiringhelli, F.; Apetoh, L. Selective degradation of PU.1 during autophagy represses the differentiation and antitumour activity of TH9 cells. Nat. Commun. 2017, 8, 559. [CrossRef] [PubMed]

48. Wei, J.; Long, L.; Yang, K.; Guy, C.; Shrestha, S.; Chen, Z.; Wu, C.; Vogel, P.; Neale, G.; Green, D.R.; et al. Autophagy enforces functional integrity of regulatory $\mathrm{T}$ cells by coupling environmental cues and metabolic homeostasis. Nat. Immunol. 2016, 17, 277-285. [CrossRef]

49. O'Sullivan, D.; van der Windt, G.J.W.; Huang, S.C.-C.; Curtis, J.D.; Chang, C.-H.; Buck, M.D.; Qiu, J.; Smith, A.M.; Lam, W.Y.; DiPlato, L.M.; et al. Memory CD8(+) T cells use cell-intrinsic lipolysis to support the metabolic programming necessary for development. Immunity 2014, 41, 75-88. [CrossRef]

50. Zhu, L.; Xie, X.; Zhang, L.; Wang, H.; Jie, Z.; Zhou, X.; Shi, J.; Zhao, S.; Zhang, B.; Cheng, X.; et al. TBK-binding protein 1 regulates IL-15-induced autophagy and NKT cell survival. Nat. Commun. 2018, 9, 2812. [CrossRef]

51. Pieper, K.; Grimbacher, B.; Eibel, H. B-cell biology and development. J. Allergy Clin. Immunol. 2013, 131, 959-971. [CrossRef] [PubMed]

52. Miller, B.C.; Zhao, Z.; Stephenson, L.M.; Cadwell, K.; Pua, H.H.; Lee, H.K.; Mizushima, N.N.; Iwasaki, A.; He, Y.-W.; Swat, W.; et al. The autophagy gene ATG5 plays an essential role in B lymphocyte development. Autophagy 2008, 4, 309-314. [CrossRef]

53. Arnold, J.; Murera, D.; Arbogast, F.; Fauny, J.-D.; Muller, S.; Gros, F. Autophagy is dispensable for B-cell development but essential for humoral autoimmune responses. Cell Death Differ. 2016, 23, 853-864. [CrossRef] [PubMed]

54. Chen, M.; Hong, M.J.; Sun, H.; Wang, L.; Shi, X.; Gilbert, B.E.; Corry, D.B.; Kheradmand, F.; Wang, J. Essential role for autophagy in the maintenance of immunological memory against influenza infection. Nat. Med. 2014, 20, 503-510. [CrossRef]

55. Chen, M.; Kodali, S.; Jang, A.; Kuai, L.; Wang, J. Requirement for autophagy in the long-term persistence but not initial formation of memory B cells. J. Immunol. 2015, 194, 2607-2615. [CrossRef] [PubMed]

56. Martinez-Martin, N.; Maldonado, P.; Gasparrini, F.; Frederico, B.; Aggarwal, S.; Gaya, M.; Tsui, C.; Burbage, M.; Keppler, S.J.; Montaner, B.; et al. A switch from canonical to noncanonical autophagy shapes B cell responses. Science 2017, 355, 641-647. [CrossRef] [PubMed]

57. Pengo, N.; Scolari, M.; Oliva, L.; Milan, E.; Mainoldi, F.; Raimondi, A.; Fagioli, C.; Merlini, A.; Mariani, E.; Pasqualetto, E.; et al. Plasma cells require autophagy for sustainable immunoglobulin production. Nat. Immunol. 2013, 14, 298-305. [CrossRef]

58. Wang, S.; Xia, P.; Huang, G.; Zhu, P.; Liu, J.; Ye, B.; Du, Y.; Fan, Z. FoxO1-mediated autophagy is required for NK cell development and innate immunity. Nat. Commun. 2016, 7, 11023. [CrossRef] [PubMed]

59. O'Sullivan, T.E.; Geary, C.D.; Weizman, O.-E.; Geiger, T.L.; Rapp, M.; Dorn, G.W.; Overholtzer, M.; Sun, J.C. Atg5 Is Essential for the Development and Survival of Innate Lymphocytes. Cell Rep. 2016, 15, 1910-1919. [CrossRef] [PubMed]

60. Morvan, M.G.; Lanier, L.L. NK cells and cancer: You can teach innate cells new tricks. Nat. Rev. Cancer 2016, 16, 7-19. [CrossRef] [PubMed]

61. Noman, M.Z.; Berchem, G.; Janji, B. Targeting autophagy blocks melanoma growth by bringing natural killer cells to the tumor battlefield. Autophagy 2018, 14, 730-732. [CrossRef] [PubMed] 
62. Baginska, J.; Viry, E.; Berchem, G.; Poli, A.; Noman, M.Z.; van Moer, K.; Medves, S.; Zimmer, J.; Oudin, A.; Niclou, S.P.; et al. Granzyme B degradation by autophagy decreases tumor cell susceptibility to natural killer-mediated lysis under hypoxia. Proc. Natl. Acad. Sci. USA 2013, 2013, 04790. [CrossRef] [PubMed]

63. Takano-Ohmuro, H.; Mukaida, M.; Kominami, E.; Morioka, K. Autophagy in embryonic erythroid cells: Its role in maturation. Eur. J. Cell Biol. 2000, 79, 759-764. [CrossRef] [PubMed]

64. Fader, C.M.; Salassa, B.N.; Grosso, R.A.; Vergara, A.N.; Colombo, M.I. Hemin induces mitophagy in a leukemic erythroblast cell line. Biol. Cell 2016, 108, 77-95. [CrossRef] [PubMed]

65. Kang, Y.-A.; Sanalkumar, R.; O'Geen, H.; Linnemann, A.K.; Chang, C.-J.; Bouhassira, E.E.; Farnham, P.J.; Keles, S.; Bresnick, E.H. Autophagy driven by a master regulator of hematopoiesis. Mol. Cell. Biol. 2012, 32, 226-239. [CrossRef] [PubMed]

66. Cao, Y.; Cai, J.; Li, X.; Yuan, N.; Zhang, S. Autophagy governs erythroid differentiation both in vitro and in vivo. Hematology 2016, 21, 225-233. [CrossRef] [PubMed]

67. Aerbajinai, W.; Giattina, M.; Lee, Y.T.; Raffeld, M.; Miller, J.L. The proapoptotic factor Nix is coexpressed with Bcl-xL during terminal erythroid differentiation. Blood 2003, 102, 712-717. [CrossRef]

68. Chen, M.; Sandoval, H.; Wang, J. Selective mitochondrial autophagy during erythroid maturation. Autophagy 2008, 4, 926-928. [CrossRef]

69. Sandoval, H.; Thiagarajan, P.; Dasgupta, S.K.; Schumacher, A.; Prchal, J.T.; Chen, M.; Wang, J. Essential role for Nix in autophagic maturation of erythroid cells. Nature 2008, 454, 232-235. [CrossRef]

70. Schwarten, M.; Mohrlüder, J.; Ma, P.; Stoldt, M.; Thielmann, Y.; Stangler, T.; Hersch, N.; Hoffmann, B.; Merkel, R.; Willbold, D. Nix directly binds to GABARAP: A possible crosstalk between apoptosis and autophagy. Autophagy 2009, 5, 690-698. [CrossRef]

71. Betin, V.M.S.; Singleton, B.K.; Parsons, S.F.; Anstee, D.J.; Lane, J.D. Autophagy facilitates organelle clearance during differentiation of human erythroblasts: Evidence for a role for ATG4 paralogs during autophagosome maturation. Autophagy 2013, 9, 881-893. [CrossRef] [PubMed]

72. Li-Harms, X.; Milasta, S.; Lynch, J.; Wright, C.; Joshi, A.; Iyengar, R.; Neale, G.; Wang, X.; Wang, Y.-D.; Prolla, T.A.; et al. Mito-protective autophagy is impaired in erythroid cells of aged mtDNA-mutator mice. Blood 2015, 125, 162-174. [CrossRef]

73. Kundu, M.; Lindsten, T.; Yang, C.-Y.; Wu, J.; Zhao, F.; Zhang, J.; Selak, M.A.; Ney, P.A.; Thompson, C.B. Ulk1 plays a critical role in the autophagic clearance of mitochondria and ribosomes during reticulocyte maturation. Blood 2008, 112, 1493-1502. [CrossRef] [PubMed]

74. Joo, J.H.; Dorsey, F.C.; Joshi, A.; Hennessy-Walters, K.M.; Rose, K.L.; McCastlain, K.; Zhang, J.; Iyengar, R.; Jung, C.H.; Suen, D.-F.; et al. Hsp90-Cdc37 chaperone complex regulates Ulk1- and Atg13-mediated mitophagy. Mol. Cell 2011, 43, 572-585. [CrossRef] [PubMed]

75. Orsini, M.; Chateauvieux, S.; Rhim, J.; Gaigneaux, A.; Cheillan, D.; Christov, C.; Dicato, M.; Morceau, F.; Diederich, M. Sphingolipid-mediated inflammatory signaling leading to autophagy inhibition converts erythropoiesis to myelopoiesis in human hematopoietic stem/progenitor cells. Cell Death Differ. 2018. [CrossRef] [PubMed]

76. Mancias, J.D.; Pontano Vaites, L.; Nissim, S.; Biancur, D.E.; Kim, A.J.; Wang, X.; Liu, Y.; Goessling, W.; Kimmelman, A.C.; Harper, J.W. Ferritinophagy via NCOA4 is required for erythropoiesis and is regulated by iron dependent HERC2-mediated proteolysis. Elife 2015, 4. [CrossRef] [PubMed]

77. Wynn, T.A.; Chawla, A.; Pollard, J.W. Macrophage biology in development, homeostasis and disease. Nature 2013, 496, 445-455. [CrossRef]

78. Ginhoux, F.; Jung, S. Monocytes and macrophages: Developmental pathways and tissue homeostasis. Nat. Rev. Immunol. 2014, 14, 392-404. [CrossRef]

79. Jacquel, A.; Obba, S.; Boyer, L.; Dufies, M.; Robert, G.; Gounon, P.; Lemichez, E.; Luciano, F.; Solary, E.; Auberger, P. Autophagy is required for CSF-1-induced macrophagic differentiation and acquisition of phagocytic functions. Blood 2012, 119, 4527-4531. [CrossRef]

80. Zhang, Y.; Morgan, M.J.; Chen, K.; Choksi, S.; Liu, Z. Induction of autophagy is essential for monocyte-macrophage differentiation. Blood 2012, 119, 2895-2905. [CrossRef]

81. Obba, S.; Hizir, Z.; Boyer, L.; Selimoglu-Buet, D.; Pfeifer, A.; Michel, G.; Hamouda, M.-A.; Gonçalvès, D.; Cerezo, M.; Marchetti, S.; et al. The PRKAA1/AMPK $\alpha 1$ pathway triggers autophagy during CSF1-induced human monocyte differentiation and is a potential target in CMML. Autophagy 2015, 11, 1114-1129. [CrossRef] [PubMed] 
82. Stranks, A.J.; Hansen, A.L.; Panse, I.; Mortensen, M.; Ferguson, D.J.P.; Puleston, D.J.; Shenderov, K.; Watson, A.S.; Veldhoen, M.; Phadwal, K.; et al. Autophagy Controls Acquisition of Aging Features in Macrophages. J. Innate Immun. 2015, 7, 375-391. [CrossRef] [PubMed]

83. Shan, M.; Qin, J.; Jin, F.; Han, X.; Guan, H.; Li, X.; Zhang, J.; Zhang, H.; Wang, Y. Autophagy suppresses isoprenaline-induced M2 macrophage polarization via the ROS/ERK and mTOR signaling pathway. Free Radic. Biol. Med. 2017, 110, 432-443. [CrossRef] [PubMed]

84. Delgado-Rizo, V.; Martínez-Guzmán, M.A.; Iñiguez-Gutierrez, L.; García-Orozco, A.; Alvarado-Navarro, A.; Fafutis-Morris, M. Neutrophil Extracellular Traps and Its Implications in Inflammation: An Overview. Front. Immunol. 2017, 8, 81. [CrossRef] [PubMed]

85. Kaplan, M.J.; Radic, M. Neutrophil extracellular traps: Double-edged swords of innate immunity. J. Immunol. 2012, 189, 2689-2695. [CrossRef] [PubMed]

86. Kim, J.-K.; Park, M.J.; Lee, H.W.; Lee, H.S.; Choi, S.R.; Song, Y.R.; Kim, H.J.; Park, H.-C.; Kim, S.G. The relationship between autophagy, increased neutrophil extracellular traps formation and endothelial dysfunction in chronic kidney disease. Clin. Immunol. 2018, 197, 189-197. [CrossRef]

87. Remijsen, Q.; Berghe, T.V.; Wirawan, E.; Asselbergh, B.; Parthoens, E.; De Rycke, R.; Noppen, S.; Delforge, M.; Willems, J.; Vandenabeele, P. Neutrophil extracellular trap cell death requires both autophagy and superoxide generation. Cell Res. 2011, 21, 290-304. [CrossRef]

88. Kajiume, T.; Kobayashi, M. Human granulocytes undergo cell death via autophagy. Cell Death Discov. 2018, 4, 111. [CrossRef]

89. Satake, S.; Hirai, H.; Hayashi, Y.; Shime, N.; Tamura, A.; Yao, H.; Yoshioka, S.; Miura, Y.; Inaba, T.; Fujita, N.; et al. $\mathrm{C} / \mathrm{EBP} \beta$ is involved in the amplification of early granulocyte precursors during candidemia-induced "emergency" granulopoiesis. J. Immunol. 2012, 189, 4546-4555. [CrossRef]

90. Riffelmacher, T.; Clarke, A.; Richter, F.C.; Stranks, A.; Pandey, S.; Danielli, S.; Hublitz, P.; Yu, Z.; Johnson, E.; Schwerd, T.; et al. Autophagy-Dependent Generation of Free Fatty Acids Is Critical for Normal Neutrophil Differentiation. Immunity 2017, 47, 466-480. [CrossRef]

91. Ocana, A.; Nieto-Jiménez, C.; Pandiella, A.; Templeton, A.J. Neutrophils in cancer: Prognostic role and therapeutic strategies. Mol. Cancer 2017, 16, 137. [CrossRef] [PubMed]

92. Zhang, X.; Shi, H.; Yuan, X.; Jiang, P.; Qian, H.; Xu, W. Tumor-derived exosomes induce N2 polarization of neutrophils to promote gastric cancer cell migration. Mol. Cancer 2018, 17, 146. [CrossRef] [PubMed]

93. Maugeri, N.; Capobianco, A.; Rovere-Querini, P.; Ramirez, G.A.; Tombetti, E.; Valle, P.D.; Monno, A.; D'Alberti, V.; Gasparri, A.M.; Franchini, S.; et al. Platelet microparticles sustain autophagy-associated activation of neutrophils in systemic sclerosis. Sci. Transl. Med. 2018, 10, eaao3089. [CrossRef] [PubMed]

94. Rizzi, M.; Carniato, F.; Tonello, S.; Migliario, M.; Invernizzi, M.; Rocchetti, V.; Marchese, L.; Renò, F. Charged molecular silica trigger in vitro NETosis in human granulocytes via both oxidative and autophagic pathways. Eur. Rev. Med. Pharmacol. Sci. 2018, 22, 7058-7068. [PubMed]

95. Park, S.Y.; Shrestha, S.; Youn, Y.-J.; Kim, J.-K.; Kim, S.-Y.; Kim, H.J.; Park, S.-H.; Ahn, W.-G.; Kim, S.; Lee, M.G.; et al. Autophagy Primes Neutrophils for Neutrophil Extracellular Trap Formation during Sepsis. Am. J. Respir. Crit. Care Med. 2017, 196, 577-589. [CrossRef] [PubMed]

96. Ma, R.; Li, T.; Cao, M.; Si, Y.; Wu, X.; Zhao, L.; Yao, Z.; Zhang, Y.; Fang, S.; Deng, R.; et al. Extracellular DNA traps released by acute promyelocytic leukemia cells through autophagy. Cell Death Dis. 2016, 7, e2283. [CrossRef] [PubMed]

97. Bhattacharya, A.; Wei, Q.; Shin, J.N.; Abdel Fattah, E.; Bonilla, D.L.; Xiang, Q.; Eissa, N.T. Autophagy Is Required for Neutrophil-Mediated Inflammation. Cell Rep. 2015, 12, 1731-1739. [CrossRef]

98. Iula, L.; Keitelman, I.A.; Sabbione, F.; Fuentes, F.; Guzman, M.; Galletti, J.G.; Gerber, P.P.; Ostrowski, M.; Geffner, J.R.; Jancic, C.C.; et al. Autophagy Mediates Interleukin-1 $\beta$ Secretion in Human Neutrophils. Front. Immunol. 2018, 9, 269. [CrossRef]

99. Machlus, K.R.; Italiano, J.E. The incredible journey: From megakaryocyte development to platelet formation. J. Cell Biol. 2013, 201, 785-796. [CrossRef]

100. Cao, Y.; Cai, J.; Zhang, S.; Yuan, N.; Li, X.; Fang, Y.; Song, L.; Shang, M.; Liu, S.; Zhao, W.; et al. Loss of autophagy leads to failure in megakaryopoiesis, megakaryocyte differentiation, and thrombopoiesis in mice. Exp. Hematol. 2015, 43, 488-494. [CrossRef]

101. Feng, W.; Chang, C.; Luo, D.; Su, H.; Yu, S.; Hua, W.; Chen, Z.; Hu, H.; Liu, W. Dissection of autophagy in human platelets. Autophagy 2014, 10, 642-651. [CrossRef] [PubMed] 
102. Alizadeh, A.A.; Eisen, M.B.; Davis, R.E.; Ma, C.; Lossos, I.S.; Rosenwald, A.; Boldrick, J.C.; Sabet, H.; Tran, T.; $\mathrm{Yu}, \mathrm{X}$.; et al. Distinct types of diffuse large B-cell lymphoma identified by gene expression profiling. Nature 2000, 403, 503-511. [CrossRef] [PubMed]

103. Friedberg, J.W. How I treat double-hit lymphoma. Blood 2017, 130, 590-596. [CrossRef] [PubMed]

104. Nicotra, G.; Mercalli, F.; Peracchio, C.; Castino, R.; Follo, C.; Valente, G.; Isidoro, C. Autophagy-active beclin-1 correlates with favourable clinical outcome in non-Hodgkin lymphomas. Mod. Pathol. 2010, 23, 937-950. [CrossRef] [PubMed]

105. Huang, J.-J.; Zhu, Y.-J.; Lin, T.-Y.; Jiang, W.-Q.; Huang, H.-Q.; Li, Z.-M. Beclin 1 expression predicts favorable clinical outcome in patients with diffuse large B-cell lymphoma treated with R-CHOP. Hum. Pathol. 2011, 42, 1459-1466. [CrossRef] [PubMed]

106. Yue, Z.; Jin, S.; Yang, C.; Levine, A.J.; Heintz, N. Beclin 1, an autophagy gene essential for early embryonic development, is a haploinsufficient tumor suppressor. Proc. Natl. Acad. Sci. USA 2003, 100, 15077-15082. [CrossRef] [PubMed]

107. Qu, X.; Yu, J.; Bhagat, G.; Furuya, N.; Hibshoosh, H.; Troxel, A.; Rosen, J.; Eskelinen, E.-L.; Mizushima, N.; Ohsumi, Y.; et al. Promotion of tumorigenesis by heterozygous disruption of the beclin 1 autophagy gene. J. Clin. Invest. 2003, 112, 1809-1820. [CrossRef]

108. Bertolo, C.; Roa, S.; Sagardoy, A.; Mena-Varas, M.; Robles, E.F.; Martinez-Ferrandis, J.I.; Sagaert, X.; Tousseyn, T.; Orta, A.; Lossos, I.S.; et al. LITAF, a BCL6 target gene, regulates autophagy in mature B-cell lymphomas. Br. J. Haematol. 2013, 162, 621-630. [CrossRef]

109. Li, Y.; Zhou, X.; Zhang, Y.; Yang, J.; Xu, Y.; Zhao, Y.; Wang, X. CUL4B regulates autophagy via JNK signaling in diffuse large B-cell lymphoma. Cell Cycle 2019. [CrossRef]

110. El-Khoury, V.; Pierson, S.; Szwarcbart, E.; Brons, N.H.C.; Roland, O.; Cherrier-De Wilde, S.; Plawny, L.; Van Dyck, E.; Berchem, G. Disruption of autophagy by the histone deacetylase inhibitor MGCD0103 and its therapeutic implication in B-cell chronic lymphocytic leukemia. Leukemia 2014, 28, 1636-1646. [CrossRef]

111. Hanihara-Tatsuzawa, F.; Miura, H.; Kobayashi, S.; Isagawa, T.; Okuma, A.; Manabe, I.; MaruYama, T. Control of Toll-like receptor-mediated T cell-independent type 1 antibody responses by the inducible nuclear protein

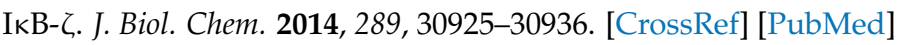

112. Fonte, E.; Vilia, M.G.; Reverberi, D.; Sana, I.; Scarfò, L.; Ranghetti, P.; Orfanelli, U.; Cenci, S.; Cutrona, G.; Ghia, P.; et al. Toll-like receptor 9 stimulation can induce $\mathrm{I \kappa B} \zeta$ expression and IgM secretion in chronic lymphocytic leukemia cells. Haematologica 2017, 102, 1901-1912. [CrossRef] [PubMed]

113. Kristensen, L.; Kristensen, T.; Abildgaard, N.; Thomassen, M.; Frederiksen, M.; Mourits-Andersen, T.; Møller, M.B. High expression of PI3K core complex genes is associated with poor prognosis in chronic lymphocytic leukemia. Leuk. Res. 2015, 39, 555-560. [CrossRef] [PubMed]

114. Narayan, G.; Arias-Pulido, H.; Koul, S.; Vargas, H.; Zhang, F.F.; Villella, J.; Schneider, A.; Terry, M.B.; Mansukhani, M.; Murty, V.V. Frequent promoter methylation of CDH1, DAPK, RARB, and HIC1 genes in carcinoma of cervix uteri: Its relationship to clinical outcome. Mol. Cancer 2003, 2, 24. [CrossRef] [PubMed]

115. Raval, A.; Tanner, S.M.; Byrd, J.C.; Angerman, E.B.; Perko, J.D.; Chen, S.-S.; Hackanson, B.; Grever, M.R.; Lucas, D.M.; Matkovic, J.J.; et al. Downregulation of death-associated protein kinase 1 (DAPK1) in chronic lymphocytic leukemia. Cell 2007, 129, 879-890. [CrossRef] [PubMed]

116. Gade, P.; Kimball, A.S.; DiNardo, A.C.; Gangwal, P.; Ross, D.D.; Boswell, H.S.; Keay, S.K.; Kalvakolanu, D.V. Death-associated Protein Kinase-1 Expression and Autophagy in Chronic Lymphocytic Leukemia Are Dependent on Activating Transcription Factor-6 and CCAAT/Enhancer-binding Protein- $\beta$. J. Biol. Chem. 2016, 291, 22030-22042. [CrossRef] [PubMed]

117. Bologna, C.; Buonincontri, R.; Serra, S.; Vaisitti, T.; Audrito, V.; Brusa, D.; Pagnani, A.; Coscia, M.; D'Arena, G.; Mereu, E.; et al. SLAMF1 regulation of chemotaxis and autophagy determines CLL patient response. J. Clin. Investig. 2016, 126, 181-194. [CrossRef]

118. Fisher, R.I.; Bernstein, S.H.; Kahl, B.S.; Djulbegovic, B.; Robertson, M.J.; De Vos, S.; Epner, E.; Krishnan, A.; Leonard, J.P.; Lonial, S.; et al. Multicenter phase II study of bortezomib in patients with relapsed or refractory mantle cell lymphoma. J. Clin. Oncol. 2006, 24, 4867-4874. [CrossRef]

119. Coiffier, B.; Ribrag, V. Exploring mammalian target of rapamycin (mTOR) inhibition for treatment of mantle cell lymphoma and other hematologic malignancies. Leuk. Lymphoma 2009, 50, 1916-1930. [CrossRef] 
120. Zhang, H.; Chen, Z.; Miranda, R.N.; Medeiros, L.J.; McCarty, N. TG2 and NF-kB Signaling Coordinates the Survival of Mantle Cell Lymphoma Cells via IL6-Mediated Autophagy. Cancer Res. 2016, 76, 6410-6423. [CrossRef]

121. Zhou, Q.; Zhao, J.; Al-Zoghaibi, F.; Zhou, A.; Wiedmer, T.; Silverman, R.H.; Sims, P.J. Transcriptional control of the human plasma membrane phospholipid scramblase 1 gene is mediated by interferon-alpha. Blood 2000, 95, 2593-2599. [PubMed]

122. Zhao, K.-W.; Li, X.; Zhao, Q.; Huang, Y.; Li, D.; Peng, Z.-G.; Shen, W.-Z.; Zhao, J.; Zhou, Q.; Chen, Z.; et al. Protein kinase Cdelta mediates retinoic acid and phorbol myristate acetate-induced phospholipid scramblase 1 gene expression: Its role in leukemic cell differentiation. Blood 2004, 104, 3731-3738. [CrossRef] [PubMed]

123. Mastorci, K.; Montico, B.; Faè, D.A.; Sigalotti, L.; Ponzoni, M.; Inghirami, G.; Dolcetti, R.; Dal Col, J. Phospholipid scramblase 1 as a critical node at the crossroad between autophagy and apoptosis in mantle cell lymphoma. Oncotarget 2016, 7, 41913-41928. [CrossRef] [PubMed]

124. Zhang, H.; Chen, Z.; Neelapu, S.S.; Romaguera, J.; McCarty, N. Hedgehog inhibitors selectively target cell migration and adhesion of mantle cell lymphoma in bone marrow microenvironment. Oncotarget 2016, 7, 14350-14365. [CrossRef] [PubMed]

125. Maclean, K.H.; Dorsey, F.C.; Cleveland, J.L.; Kastan, M.B. Targeting lysosomal degradation induces p53-dependent cell death and prevents cancer in mouse models of lymphomagenesis. J. Clin. Investig. 2008, 118, 79-88. [CrossRef] [PubMed]

126. Kuehl, W.M.; Bergsagel, P.L. Molecular pathogenesis of multiple myeloma and its premalignant precursor. J. Clin. Invest. 2012, 122, 3456-3463. [CrossRef]

127. Alexanian, R.; Bonnet, J.; Gehan, E.; Haut, A.; Hewlett, J.; Lane, M.; Monto, R.; Wilson, H. Combination chemotherapy for multiple myeloma. Cancer 1972, 30, 382-389. [CrossRef]

128. Mcelwain, T.J.; Powles, R.L. High-Dose Intravenous Melphalan For Plasma-Cell Leukaemia And Myeloma. Lancet 1983, 322, 822-824. [CrossRef]

129. Ma, M.H.; Yang, H.H.; Parker, K.; Manyak, S.; Friedman, J.M.; Altamirano, C.; Wu, Z.; Borad, M.J.; Frantzen, M.; Roussos, E.; et al. The proteasome inhibitor PS-341 markedly enhances sensitivity of multiple myeloma tumor cells to chemotherapeutic agents. Clin. Cancer Res. 2003, 9, 1136-1144.

130. Jelinek, T.; Hajek, R. PD-1/PD-L1 inhibitors in multiple myeloma: The present and the future. OncoImmunology 2016, 5, e1254856. [CrossRef]

131. Allegra, A.; Sant'Antonio, E.; Penna, G.; Alonci, A.; D'Angelo, A.; Russo, S.; Cannavò, A.; Gerace, D.; Musolino, C. Novel therapeutic strategies in multiple myeloma: Role of the heat shock protein inhibitors. Eur. J. Haematol. 2011, 86, 93-110. [CrossRef] [PubMed]

132. Mitchell, J.S.; Li, N.; Weinhold, N.; Försti, A.; Ali, M.; van Duin, M.; Thorleifsson, G.; Johnson, D.C.; Chen, B.; Halvarsson, B.-M.; et al. Genome-wide association study identifies multiple susceptibility loci for multiple myeloma. Nat. Commun. 2016, 7, 12050. [CrossRef] [PubMed]

133. Went, M.; Sud, A.; Försti, A.; Halvarsson, B.-M.; Weinhold, N.; Kimber, S.; van Duin, M.; Thorleifsson, G.; Holroyd, A.; Johnson, D.C.; et al. Identification of multiple risk loci and regulatory mechanisms influencing susceptibility to multiple myeloma. Nat. Commun. 2018, 9, 3707. [CrossRef] [PubMed]

134. Jung, G.; Roh, J.; Lee, H.; Gil, M.; Yoon, D.H.; Suh, C.; Jang, S.; Park, C.-J.; Huh, J.; Park, C.-S. Autophagic Markers BECLIN 1 and LC3 are Associated with Prognosis of Multiple Myeloma. Acta Haematol. 2015, 134, 17-24. [CrossRef] [PubMed]

135. De Veirman, K.; Menu, E.; Maes, K.; De Beule, N.; De Smedt, E.; Maes, A.; Vlummens, P.; Fostier, K.; Kassambara, A.; Moreaux, J.; et al. Myeloid-derived suppressor cells induce multiple myeloma cell survival by activating the AMPK pathway. Cancer Lett. 2019, 442, 233-241. [CrossRef] [PubMed]

136. Gao, D.; Lv, A.-E.; Li, H.-P.; Han, D.-H.; Zhang, Y.-P. LncRNA MALAT-1 Elevates HMGB1 to Promote Autophagy Resulting in Inhibition of Tumor Cell Apoptosis in Multiple Myeloma. J. Cell. Biochem. 2017, 118, 3341-3348. [CrossRef] [PubMed]

137. Desantis, A.; Bruno, T.; Catena, V.; De Nicola, F.; Goeman, F.; Iezzi, S.; Sorino, C.; Ponzoni, M.; Bossi, G.; Federico, V.; et al. Che-1-induced inhibition of mTOR pathway enables stress-induced autophagy. EMBO J. 2015, 34, 1214-1230. [CrossRef] [PubMed]

138. Hoang, B.; Benavides, A.; Shi, Y.; Frost, P.; Lichtenstein, A. Effect of autophagy on multiple myeloma cell viability. Mol. Cancer Ther. 2009, 8, 1974-1984. [CrossRef] [PubMed] 
139. Wang, G.; Zhou, P.; Chen, X.; Zhao, L.; Tan, J.; Yang, Y.; Fang, Y.; Zhou, J. The novel autophagy inhibitor elaiophylin exerts antitumor activity against multiple myeloma with mutant TP53 in part through endoplasmic reticulum stress-induced apoptosis. Cancer Biol. Ther. 2017, 18, 584-595. [CrossRef] [PubMed]

140. Lamy, L.; Ngo, V.N.; Emre, N.C.T.; Shaffer, A.L.; Yang, Y.; Tian, E.; Nair, V.; Kruhlak, M.J.; Zingone, A.; Landgren, O.; et al. Control of autophagic cell death by caspase-10 in multiple myeloma. Cancer Cell 2013, 23, 435-449. [CrossRef] [PubMed]

141. Zhou, H.; Luo, W.; Zeng, C.; Zhang, Y.; Wang, L.; Yao, W.; Nie, C. PP2A mediates apoptosis or autophagic cell death in multiple myeloma cell lines. Oncotarget 2017, 8, 80770-80789. [CrossRef] [PubMed]

142. Cesarman, E. Gammaherpesviruses and lymphoproliferative disorders. Annu. Rev. Pathol. 2014, 9, $349-372$. [CrossRef] [PubMed]

143. Simonelli, C.; Spina, M.; Cinelli, R.; Talamini, R.; Tedeschi, R.; Gloghini, A.; Vaccher, E.; Carbone, A.; Tirelli, U. Clinical features and outcome of primary effusion lymphoma in HIV-infected patients: A single-institution study. J. Clin. Oncol. 2003, 21, 3948-3954. [CrossRef] [PubMed]

144. Masud Alam, M.; Kariya, R.; Kawaguchi, A.; Matsuda, K.; Kudo, E.; Okada, S. Inhibition of autophagy by chloroquine induces apoptosis in primary effusion lymphoma in vitro and in vivo through induction of endoplasmic reticulum stress. Apoptosis 2016, 21, 1191-1201. [CrossRef] [PubMed]

145. Tsai, C.-Y.; Chen, C.-Y.; Chiou, Y.-H.; Shyu, H.-W.; Lin, K.-H.; Chou, M.-C.; Huang, M.-H.; Wang, Y.-F. Epigallocatechin-3-Gallate Suppresses Human Herpesvirus 8 Replication and Induces ROS Leading to Apoptosis and Autophagy in Primary Effusion Lymphoma Cells. Int. J. Mol. Sci. 2018, 19, 16. [CrossRef] [PubMed]

146. Turner, S.D.; Lamant, L.; Kenner, L.; Brugières, L. Anaplastic large cell lymphoma in paediatric and young adult patients. Br. J. Haematol. 2016, 173, 560-572. [CrossRef] [PubMed]

147. Lowe, E.J.; Gross, T.G. Anaplastic large cell lymphoma in children and adolescents. Pediatr. Hematol. Oncol. 2013, 30, 509-519. [CrossRef]

148. Morris, S.W.; Kirstein, M.N.; Valentine, M.B.; Dittmer, K.G.; Shapiro, D.N.; Saltman, D.L.; Look, A.T. Fusion of a kinase gene, ALK, to a nucleolar protein gene, NPM, in non- Hodgkin's lymphoma. Science 1994, 263, 1281-1284. [CrossRef]

149. Chiarle, R.; Voena, C.; Ambrogio, C.; Piva, R.; Inghirami, G. The anaplastic lymphoma kinase in the pathogenesis of cancer. Nat. Rev. Cancer 2008, 8, 11-23. [CrossRef]

150. Roskoski, R. Anaplastic lymphoma kinase (ALK): Structure, oncogenic activation, and pharmacological inhibition. Pharmacol. Res. 2013, 68, 68-94. [CrossRef]

151. Christensen, J.G.; Zou, H.Y.; Arango, M.E.; Li, Q.; Lee, J.H.; McDonnell, S.R.; Yamazaki, S.; Alton, G.R.; Mroczkowski, B.; Los, G. Cytoreductive antitumor activity of PF-2341066, a novel inhibitor of anaplastic lymphoma kinase and c-Met, in experimental models of anaplastic large-cell lymphoma. Mol. Cancer Ther 2007, 6, 3314-3322. [CrossRef] [PubMed]

152. Mologni, L. Current and future treatment of anaplastic lymphoma kinase-rearranged cancer. World J. Clin. Oncol. 2015, 6, 104-108. [CrossRef] [PubMed]

153. Crescenzo, R.; Inghirami, G. Anaplastic lymphoma kinase inhibitors. Curr. Opin. Pharmacol. 2015, $23,39-44$. [CrossRef] [PubMed]

154. Gambacorti Passerini, C.; Farina, F.; Stasia, A.; Redaelli, S.; Ceccon, M.; Mologni, L.; Messa, C.; Guerra, L.; Giudici, G.; Sala, E.; et al. Crizotinib in advanced, chemoresistant anaplastic lymphoma kinase-positive lymphoma patients. J. Natl. Cancer Inst. 2014, 106, djt378. [CrossRef] [PubMed]

155. Mosse, Y.P.; Lim, M.S.; Voss, S.D.; Wilner, K.; Ruffner, K.; Laliberte, J.; Rolland, D.; Balis, F.M.; Maris, J.M.; Weigel, B.J.; et al. Safety and activity of crizotinib for paediatric patients with refractory solid tumours or anaplastic large-cell lymphoma: A Children's Oncology Group phase 1 consortium study. Lancet Oncol. 2013, 14, 472-480. [CrossRef]

156. Lai, R.; Ingham, R.J. The pathobiology of the oncogenic tyrosine kinase NPM-ALK: A brief update. Ther. Adv. Hematol. 2013, 4, 119-131. [CrossRef] [PubMed]

157. Mastini, C.; Martinengo, C.; Inghirami, G.; Chiarle, R. Anaplastic lymphoma kinase: An oncogene for tumor vaccination. J. Mol. Med. 2009, 87, 669-677. [CrossRef] [PubMed]

158. Mitou, G.; Frentzel, J.; Desquesnes, A.; Le Gonidec, S.; AlSaati, T.; Beau, I.; Lamant, L.; Meggetto, F.; Espinos, E.; Codogno, P.; et al. Targeting autophagy enhances the anti-tumoral action of crizotinib in ALK-positive anaplastic large cell lymphoma. Oncotarget 2015, 6, 30149-30164. [CrossRef] 
159. Fisher, R.I.; LeBlanc, M.; Press, O.W.; Maloney, D.G.; Unger, J.M.; Miller, T.P. New Treatment Options Have Changed the Survival of Patients with Follicular Lymphoma. JCO 2005, 23, 8447-8452. [CrossRef]

160. Hiddemann, W.; Kneba, M.; Dreyling, M.; Schmitz, N.; Lengfelder, E.; Schmits, R.; Reiser, M.; Metzner, B.; Harder, H.; Hegewisch-Becker, S.; et al. Frontline therapy with rituximab added to the combination of cyclophosphamide, doxorubicin, vincristine, and prednisone ( $\mathrm{CHOP}$ ) significantly improves the outcome for patients with advanced-stage follicular lymphoma compared with therapy with CHOP alone: Results of a prospective randomized study of the German Low-Grade Lymphoma Study Group. Blood 2005, 106, 3725-3732. [PubMed]

161. Martinelli, G.; Schmitz, S.-F.H.; Utiger, U.; Cerny, T.; Hess, U.; Bassi, S.; Okkinga, E.; Stupp, R.; Stahel, R.; Heizmann, M.; et al. Long-term follow-up of patients with follicular lymphoma receiving single-agent rituximab at two different schedules in trial SAKK 35/98. J. Clin. Oncol. 2010, 28, 4480-4484. [CrossRef] [PubMed]

162. Kridel, R.; Sehn, L.H.; Gascoyne, R.D. Pathogenesis of follicular lymphoma. J. Clin. Investig. 2012, 122, 3424-3431. [CrossRef] [PubMed]

163. Gravelle, P.; Do, C.; Franchet, C.; Mueller, S.; Oberic, L.; Ysebaert, L.; Larocca, L.M.; Hohaus, S.; Calmels, M.-N.; Frenois, F.-X.; et al. Impaired functional responses in follicular lymphoma CD8+TIM-3+ T lymphocytes following TCR engagement. Oncoimmunology 2016, 5, e1224044. [CrossRef] [PubMed]

164. McCarthy, A.; Marzec, J.; Clear, A.; Petty, R.D.; Coutinho, R.; Matthews, J.; Wilson, A.; Iqbal, S.; Calaminici, M.; Gribben, J.G.; et al. Dysregulation of autophagy in human follicular lymphoma is independent of overexpression of BCL-2. Oncotarget 2014, 5, 11653-11668. [CrossRef] [PubMed]

165. Giatromanolaki, A.; Koukourakis, M.I.; Pouliliou, S.; Gatter, K.C.; Pezzella, F.; Harris, A.L.; Sivridis, E. Overexpression of LC3A autophagy protein in follicular and diffuse large B-cell lymphomas. Hematol. Oncol. Stem Cell Ther. 2013, 6, 20-25. [CrossRef] [PubMed]

166. Mullighan, C.G.; Goorha, S.; Radtke, I.; Miller, C.B.; Coustan-Smith, E.; Dalton, J.D.; Girtman, K.; Mathew, S.; Ma, J.; Pounds, S.B.; et al. Genome-wide analysis of genetic alterations in acute lymphoblastic leukaemia. Nature 2007, 446, 758-764. [CrossRef] [PubMed]

167. Holleman, A.; Cheok, M.H.; den Boer, M.L.; Yang, W.; Veerman, A.J.P.; Kazemier, K.M.; Pei, D.; Cheng, C.; Pui, C.-H.; Relling, M.V.; et al. Gene-expression patterns in drug-resistant acute lymphoblastic leukemia cells and response to treatment. N. Engl. J. Med. 2004, 351, 533-542. [CrossRef]

168. Andersson, A.K.; Ma, J.; Wang, J.; Chen, X.; Gedman, A.L.; Dang, J.; Nakitandwe, J.; Holmfeldt, L.; Parker, M.; Easton, J.; et al. The landscape of somatic mutations in infant MLL-rearranged acute lymphoblastic leukemias. Nat. Genet. 2015, 47, 330-337. [CrossRef]

169. Ottmann, O.G.; Wassmann, B.; Pfeifer, H.; Giagounidis, A.; Stelljes, M.; Duhrsen, U.; Schmalzing, M.; Wunderle, L.; Binckebanck, A.; Hoelzer, D. Imatinib compared with chemotherapy as front-line treatment of elderly patients with Philadelphia chromosome-positive acute lymphoblastic leukemia (Ph+ALL). Cancer 2007, 109, 2068-2076. [CrossRef]

170. Kantarjian, H.; Thomas, D.; Wayne, A.S.; O’Brien, S. Monoclonal antibody-based therapies: A new dawn in the treatment of acute lymphoblastic leukemia. J. Clin. Oncol. 2012, 30, 3876-3883. [CrossRef]

171. Grupp, S.A.; Kalos, M.; Barrett, D.; Aplenc, R.; Porter, D.L.; Rheingold, S.R.; Teachey, D.T.; Chew, A.; Hauck, B.; Wright, J.F.; et al. Chimeric antigen receptor-modified T cells for acute lymphoid leukemia. N. Engl. J. Med. 2013, 368, 1509-1518. [CrossRef] [PubMed]

172. Niu, Y.-N.; Liu, Q.-Q.; Zhang, S.-P.; Yuan, N.; Cao, Y.; Cai, J.-Y.; Lin, W.-W.; Xu, F.; Wang, Z.-J.; Chen, B.; et al. Alternative messenger RNA splicing of autophagic gene Beclin 1 in human B-cell acute lymphoblastic leukemia cells. Asian Pac. J. Cancer Prev. 2014, 15, 2153-2158. [CrossRef] [PubMed]

173. Wang, Z.; Xu, F.; Yuan, N.; Niu, Y.; Lin, W.; Cao, Y.; Cai, J.; Song, L.; Li, X.; Fang, Y.; et al. Rapamycin inhibits pre-B acute lymphoblastic leukemia cells by downregulating DNA and RNA polymerases. Leuk. Res. 2014, 38, 940-947. [CrossRef] [PubMed]

174. Simioni, C.; Cani, A.; Martelli, A.M.; Zauli, G.; Tabellini, G.; McCubrey, J.; Capitani, S.; Neri, L.M. Activity of the novel mTOR inhibitor Torin-2 in B-precursor acute lymphoblastic leukemia and its therapeutic potential to prevent Akt reactivation. Oncotarget 2014, 5, 10034-10047. [CrossRef] [PubMed]

175. Jia, L.; Gopinathan, G.; Sukumar, J.T.; Gribben, J.G. Blocking autophagy prevents bortezomib-induced NF- $\mathrm{BB}$ activation by reducing I- $\mathrm{kB} \alpha$ degradation in lymphoma cells. PLoS ONE 2012, 7, e32584. [CrossRef] [PubMed] 
176. Zang, C.; Eucker, J.; Liu, H.; Coordes, A.; Lenarz, M.; Possinger, K.; Scholz, C.W. Inhibition of pan-class I phosphatidyl-inositol-3-kinase by NVP-BKM120 effectively blocks proliferation and induces cell death in diffuse large B-cell lymphoma. Leuk. Lymphoma 2014, 55, 425-434. [CrossRef] [PubMed]

177. Yuan, H.; He, M.; Cheng, F.; Bai, R.; da Silva, S.R.; Aguiar, R.C.T.; Gao, S.-J. Tenovin-6 inhibits proliferation and survival of diffuse large B-cell lymphoma cells by blocking autophagy. Oncotarget 2017, 8, 14912-14924. [CrossRef] [PubMed]

178. Cheng, C.; Wang, T.; Song, Z.; Peng, L.; Gao, M.; Hermine, O.; Rousseaux, S.; Khochbin, S.; Mi, J.-Q.; Wang, J. Induction of autophagy and autophagy-dependent apoptosis in diffuse large B-cell lymphoma by a new antimalarial artemisinin derivative, SM1044. Cancer Med. 2018, 7, 380-396. [CrossRef] [PubMed]

179. Li, L.-J.; Chai, Y.; Guo, X.-J.; Chu, S.-L.; Zhang, L.-S. The effects of the long non-coding RNA MALAT-1 regulated autophagy-related signaling pathway on chemotherapy resistance in diffuse large B-cell lymphoma. Biomed. Pharmacother. 2017, 89, 939-948. [CrossRef] [PubMed]

180. Han, J.; Hou, W.; Goldstein, L.A.; Lu, C.; Stolz, D.B.; Yin, X.M.; Rabinowich, H. Involvement of protective autophagy in TRAIL resistance of apoptosis-defective tumor cells. J. Biol. Chem. 2008, 283, 19665-19677. [CrossRef] [PubMed]

181. Amrein, L.; Soulières, D.; Johnston, J.B.; Aloyz, R. P53 and autophagy contribute to dasatinib resistance in primary CLL lymphocytes. Leuk. Res. 2011, 35, 99-102. [CrossRef] [PubMed]

182. Kovaleva, V.; Mora, R.; Park, Y.J.; Plass, C.; Chiramel, A.I.; Bartenschlager, R.; Doḧner, H.; Stilgenbauer, S.; Pscherer, A.; Lichter, P.; et al. miRNA-130a targets ATG2B and DICER1 to inhibit autophagy and trigger killing of chronic lymphocytic leukemia cells. Cancer Res. 2012, 72, 1763-1772. [CrossRef] [PubMed]

183. Stellrecht, C.M.; Chen, L.S.; Ayres, M.L.; Dennison, J.B.; Shentu, S.; Chen, Y.; Keating, M.J.; Wierda, W.G.; Gandhi, V. Chlorinated adenosine analogue induces AMPK and autophagy in chronic lymphocytic leukaemia cells during therapy. Br. J. Haematol. 2017, 179, 266-271. [CrossRef] [PubMed]

184. El-Khoury, V.; Moussay, E.; Janji, B.; Palissot, V.; Aouali, N.; Brons, N.H.C.; Van Moer, K.; Pierson, S.; Van Dyck, E.; Berchem, G. The histone deacetylase inhibitor MGCD0103 induces apoptosis in B-cell chronic lymphocytic leukemia cells through a mitochondria-mediated caspase activation cascade. Mol. Cancer Ther. 2010, 9, 1349-1360. [CrossRef] [PubMed]

185. MacCallum, S.F.; Groves, M.J.; James, J.; Murray, K.; Appleyard, V.; Prescott, A.R.; Drbal, A.A.; Nicolaou, A.; Cunningham, J.; Haydock, S.; et al. Dysregulation of autophagy in chronic lymphocytic leukemia with the small-molecule Sirtuin inhibitor Tenovin-6. Sci. Rep. 2013, 3, 1275. [CrossRef] [PubMed]

186. Yuan, H.; Tan, B.; Gao, S.-J. Tenovin-6 impairs autophagy by inhibiting autophagic flux. Cell Death Dis. 2017, 8, e2608. [CrossRef] [PubMed]

187. Ding, L.; Zhang, W.; Yang, L.; Pelicano, H.; Zhou, K.; Yin, R.; Huang, R.; Zeng, J. Targeting the autophagy in bone marrow stromal cells overcomes resistance to vorinostat in chronic lymphocytic leukemia. Onco Targets Ther. 2018, 11, 5151-5170. [CrossRef]

188. Chen, Z.; Teo, A.E.; McCarty, N. ROS-induced CXCR4 signaling regulates mantle cell lymphoma (MCL) cell survival and drug resistance in the bone marrow microenvironment via autophagy. Clin. Cancer Res. 2016, 22, 187-199. [CrossRef]

189. Xiao, Y.; Guan, J. 17-AAG enhances the cytotoxicity of flavopiridol in mantle cell lymphoma via autophagy suppression. Neoplasma 2015, 62, 391-397. [CrossRef]

190. Alinari, L.; Baiocchi, R.A.; Prætorius-Ibba, M. FTY720-induced blockage of autophagy enhances anticancer efficacy of milatuzumab in mantle cell lymphoma: Is FTY720 the next autophagy-blocking agent in lymphoma treatment? Autophagy 2012, 8, 416-417. [CrossRef]

191. Alinari, L.; Yu, B.; Christian, B.A.; Yan, F.; Shin, J.; Lapalombella, R.; Hertlein, E.; Lustberg, M.E.; Quinion, C.; Zhang, X.; et al. Combination anti-CD74 (milatuzumab) and anti-CD20 (rituximab) monoclonal antibody therapy has in vitro and in vivo activity in mantle cell lymphoma. Blood 2011, 117, 4530-4541. [CrossRef] [PubMed]

192. Heine, S.; Kleih, M.; Giménez, N.; Böpple, K.; Ott, G.; Colomer, D.; Aulitzky, W.E.; van der Kuip, H.; Silkenstedt, E. Cyclin D1-CDK4 activity drives sensitivity to bortezomib in mantle cell lymphoma by blocking autophagy-mediated proteolysis of NOXA. J. Hematol. Oncol. 2018, 11, 112. [CrossRef] [PubMed]

193. Rosich, L.; Xargay-Torrent, S.; López-Guerra, M.; Campo, E.; Colomer, D.; Roué, G. Counteracting autophagy overcomes resistance to everolimus in mantle cell lymphoma. Clin. Cancer Res. 2012, 18, 5278-5289. [CrossRef] [PubMed] 
194. Nahimana, A.; Attinger, A.; Aubry, D.; Greaney, P.; Ireson, C.; Thougaard, A.V.; Tjrnelund, J.; Dawson, K.M.; Dupuis, M.; Duchosal, M.A. The NAD biosynthesis inhibitor APO866 has potent antitumor activity against hematologic malignancies. Blood 2009, 113, 3276-3286. [CrossRef] [PubMed]

195. Ginet, V.; Puyal, J.; Rummel, C.; Aubry, D.; Breton, C.; Cloux, A.J.; Majjigapu, S.R.; Sordat, B.; Vogel, P.; Bruzzone, S.; et al. A critical role of autophagy in antileukemia/lymphoma effects of APO866, an inhibitor of NAD biosynthesis. Autophagy 2014, 10, 603-617. [CrossRef] [PubMed]

196. Amaravadi, R.K.; Yu, D.; Lum, J.J.; Bui, T.; Christophorou, M.A.; Evan, G.I.; Thomas-Tikhonenko, A.; Thompson, C.B. Autophagy inhibition enhances therapy-induced apoptosis in a Myc-induced model of lymphoma. J. Clin. Investig. 2007, 117, 326-336. [CrossRef] [PubMed]

197. Hart, L.S.; Cunningham, J.T.; Datta, T.; Dey, S.; Tameire, F.; Lehman, S.L.; Qiu, B.; Zhang, H.; Cerniglia, G.; Bi, M.; et al. ER stress-mediated autophagy promotes Myc-dependent transformation and tumor growth. J. Clin. Investig. 2012, 122, 4621-4634. [CrossRef]

198. Ni, Z.; Dai, X.; Wang, B.; Ding, W.; Cheng, P.; Xu, L.; Lian, J.; He, F. Natural Bcl-2 inhibitor (-)-gossypol induces protective autophagy via reactive oxygen species-high mobility group box 1 pathway in Burkitt lymphoma. Leuk. Lymphoma 2013, 54, 2263-2268. [CrossRef]

199. Zeng, X.; Li, Y.; Fan, J.; Zhao, H.; Xian, Z.; Sun, Y.; Wang, Z.; Wang, S.; Zhang, G.; Ju, D. Recombinant human arginase induced caspase-dependent apoptosis and autophagy in non-Hodgkin's lymphoma cells. Cell Death Dis. 2013, 4, e840. [CrossRef]

200. Métayer, L.E.; Brown, R.D.; Carlebur, S.; Burke, G.A.A.; Brown, G.C. Mechanisms of cell death induced by arginase and asparaginase in precursor B-cell lymphoblasts. Apoptosis 2018. [CrossRef]

201. Fan, J.; Zeng, X.; Li, Y.; Wang, S.; Yang, P.; Cao, Z.; Wang, Z.; Song, P.; Mei, X.; Ju, D. A novel therapeutic approach against B-cell non-Hodgkin's lymphoma through co-inhibition of Hedgehog signaling pathway and autophagy. Tumour Biol. 2016, 37, 7305-7314. [CrossRef] [PubMed]

202. Pujals, A.; Favre, L.; Pioche-Durieu, C.; Robert, A.; Meurice, G.; Le Gentil, M.; Chelouah, S.; Martin-Garcia, N.; Le Cam, E.; Guettier, C.; et al. Constitutive autophagy contributes to resistance to TP53-mediated apoptosis in Epstein-Barr virus-positive latency III B-cell lymphoproliferations. Autophagy 2015, 11, 2275-2287. [CrossRef] [PubMed]

203. Fan, J.; Zeng, X.; Li, Y.; Wang, S.; Wang, Z.; Sun, Y.; Gao, H.; Zhang, G.; Feng, M.; Ju, D. Autophagy Plays a Critical Role in ChLym-1-Induced Cytotoxicity of Non-Hodgkin's Lymphoma Cells. PLoS ONE 2013, 8, e72478. [CrossRef] [PubMed]

204. Granato, M.; Rizzello, C.; Romeo, M.A.; Yadav, S.; Santarelli, R.; D’Orazi, G.; Faggioni, A.; Cirone, M. Concomitant reduction of c-Myc expression and PI3K/AKT/mTOR signaling by quercetin induces a strong cytotoxic effect against Burkitt's lymphoma. Int. J. Biochem. Cell Biol. 2016, 79, 393-400. [CrossRef] [PubMed]

205. Li, C.-L.; Wei, H.-L.; Chen, J.; Wang, B.; Xie, B.; Fan, L.-L.; Li, L.-J. Arsenic trioxide induces autophagy and antitumor effects in Burkitt's lymphoma Raji cells. Oncol. Rep. 2014, 32, 1557-1563. [CrossRef]

206. Dong, L.H.; Cheng, S.; Zheng, Z.; Wang, L.; Shen, Y.; Shen, Z.X.; Chen, S.J.; Zhao, W.L. Histone deacetylase inhibitor potentiated the ability of MTOR inhibitor to induce autophagic cell death in Burkitt leukemia/lymphoma. J. Hematol. Oncol. 2013, 6, 1-11. [CrossRef]

207. Ono, K.; Sato, T.; Iyama, S.; Tatekoshi, A.; Hashimoto, A.; Kamihara, Y.; Horiguchi, H.; Kikuchi, S.; Kawano, Y.; Takada, K.; et al. A novel strategy inducing autophagic cell death in Burkitt's lymphoma cells with anti-CD19-targeted liposomal rapamycin. Blood Cancer J. 2014, 4, e180. [CrossRef]

208. Turzanski, J.; Daniels, I.; Haynes, A.P. Involvement of macroautophagy in the caspase-independent killing of Burkitt lymphoma cell lines by rituximab. Br. J. Haematol. 2009, 145, 137-140. [CrossRef]

209. Oliva, L.; Cenci, S. Autophagy in plasma cell pathophysiology. Front. Immunol. 2014, 5, 103. [CrossRef]

210. Pan, Y.; Gao, Y.; Chen, L.; Gao, G.; Dong, H.; Yang, Y.; Dong, B.; Chen, X. Targeting autophagy augments in vitro and in vivo antimyeloma activity of DNA-damaging chemotherapy. Clin. Cancer Res. 2011, 17, 3248-3258. [CrossRef]

211. Guo, X.; He, D.; Zhang, E.; Chen, J.; Chen, Q.; Li, Y.; Yang, L.; Yang, Y.; Zhao, Y.; Wang, G.; et al. HMGB1 knockdown increases MM cell vulnerability by regulating autophagy and DNA damage repair. J. Exp. Clin. Cancer Res. 2018, 37, 205. [CrossRef] [PubMed]

212. Chen, S.; Zhang, Y.; Zhou, L.; Leng, Y.; Lin, H.; Kmieciak, M.; Pei, X.Y.; Jones, R.; Orlowski, R.Z.; Dai, Y.; et al. A Bim-targeting strategy overcomes adaptive bortezomib resistance in myeloma through a novel link between autophagy and apoptosis. Blood 2014, 124, 2687-2697. [CrossRef] [PubMed] 
213. Kaliszczak, M.; van Hechanova, E.; Li, Y.; Alsadah, H.; Parzych, K.; Auner, H.W.; Aboagye, E.O. The HDAC6 inhibitor C1A modulates autophagy substrates in diverse cancer cells and induces cell death. Br. J. Cancer 2018, 119, 1278-1287. [CrossRef] [PubMed]

214. Ma, R.; Zhang, Y.; Wang, W.; Wu, J.; Yang, Q.; Xu, W.; Jiang, S.; Han, Y.; Yu, K.; Zhang, S. Inhibition of autophagy enhances the antitumour activity of tigecycline in multiple myeloma. J. Cell. Mol. Med. 2018, 22, 5955-5963. [CrossRef]

215. Zhao, X.; Fang, Y.; Yang, Y.; Qin, Y.; Wu, P.; Wang, T.; Lai, H.; Meng, L.; Wang, D.; Zheng, Z.; et al. Elaiophylin, a novel autophagy inhibitor, exerts antitumor activity as a single agent in ovarian cancer cells. Autophagy 2015, 11, 1849-1863. [CrossRef] [PubMed]

216. Jagannathan, S.; Abdel-Malek, M.A.Y.; Malek, E.; Vad, N.; Latif, T.; Anderson, K.C.; Driscoll, J.J. Pharmacologic screens reveal metformin that suppresses GRP78-dependent autophagy to enhance the anti-myeloma effect of bortezomib. Leukemia 2015, 29, 2184-2191. [CrossRef] [PubMed]

217. Jarauta, V.; Jaime, P.; Gonzalo, O.; de Miguel, D.; Ramírez-Labrada, A.; Martínez-Lostao, L.; Anel, A.; Pardo, J.; Marzo, I.; Naval, J. Inhibition of autophagy with chloroquine potentiates carfilzomib-induced apoptosis in myeloma cells in vitro and in vivo. Cancer Lett. 2016, 382, 1-10. [CrossRef]

218. Baranowska, K.; Misund, K.; Starheim, K.K.; Holien, T.; Johansson, I.; Darvekar, S.; Buene, G.; Waage, A.; Bjørkøy, G.; Sundan, A. Hydroxychloroquine potentiates carfilzomib toxicity towards myeloma cells. Oncotarget 2016, 7, 70845-70856. [CrossRef]

219. Lu, Y.; Wang, Y.; Xu, H.; Shi, C.; Jin, F.; Li, W. Profilin 1 induces drug resistance through Beclin1 complex-mediated autophagy in multiple myeloma. Cancer Sci. 2018, 109, 2706-2716. [CrossRef]

220. Zhang, H.; Pang, Y.; Ma, C.; Li, J.; Wang, H.; Shao, Z. ClC5 Decreases the Sensitivity of Multiple Myeloma Cells to Bortezomib via Promoting Prosurvival Autophagy. Oncol. Res. 2018, 26, 421-429. [CrossRef]

221. Lu, D.; Yang, C.; Zhang, Z.; Cong, Y.; Xiao, M. Knockdown of Linc00515 Inhibits Multiple Myeloma Autophagy and Chemoresistance by Upregulating miR-140-5p and Downregulating ATG14. Cell. Physiol. Biochem. 2018, 48, 2517-2527. [CrossRef]

222. Milan, E.; Perini, T.; Resnati, M.; Orfanelli, U.; Oliva, L.; Raimondi, A.; Cascio, P.; Bachi, A.; Marcatti, M.; Ciceri, F.; et al. A plastic SQSTM1/p62-dependent autophagic reserve maintains proteostasis and determines proteasome inhibitor susceptibility in multiple myeloma cells. Autophagy 2015, 11, 1161-1178. [CrossRef] [PubMed]

223. Chen, Q.; Xie, W.; Kuhn, D.J.; Voorhees, P.M.; Lopez-Girona, A.; Mendy, D.; Corral, L.G.; Krenitsky, V.P.; $\mathrm{Xu}$, W.; Moutouh-de Parseval, L.; et al. Targeting the p27 E3 ligase SCF(Skp2) results in p27- and Skp2-mediated cell-cycle arrest and activation of autophagy. Blood 2008, 111, 4690-4699. [CrossRef] [PubMed]

224. Fu, Y.-F.; Liu, X.; Gao, M.; Zhang, Y.-N.; Liu, J. Endoplasmic reticulum stress induces autophagy and apoptosis while inhibiting proliferation and drug resistance in multiple myeloma through the PI3K/Akt/mTOR signaling pathway. Oncotarget 2017, 8, 61093-61106. [CrossRef] [PubMed]

225. Desantis, V.; Saltarella, I.; Lamanuzzi, A.; Mariggiò, M.A.; Racanelli, V.; Vacca, A.; Frassanito, M.A. Autophagy: A New Mechanism of Prosurvival and Drug Resistance in Multiple Myeloma. Transl. Oncol. 2018, 11, 1350-1357. [CrossRef]

226. Yun, Z.; Zhichao, J.; Hao, Y.; Ou, J.; Ran, Y.; Wen, D.; Qun, S. Targeting autophagy in multiple myeloma. Leuk. Res. 2017, 59, 97-104. [CrossRef]

227. Sommermann, T.; O’Neill, K.; Plas, D.R.; Cahir-McFarland, E. IKK $\beta$ and NF-KB transcription govern lymphoma cell survival through AKT-induced plasma membrane trafficking of GLUT1. Cancer Res. 2011, 7291-7300. [CrossRef] [PubMed]

228. Granato, M.; Santarelli, R.; Lotti, L.V.; Di Renzo, L.; Gonnella, R.; Garufi, A.; Trivedi, P.; Frati, L.; D’Orazi, G.; Faggioni, A.; et al. JNK and macroautophagy activation by bortezomib has a pro-survival effect in primary effusion lymphoma cells. PLoS ONE 2013, 8, e75965. [CrossRef] [PubMed]

229. Granato, M.; Rizzello, C.; Gilardini Montani, M.S.; Cuomo, L.; Vitillo, M.; Santarelli, R.; Gonnella, R.; D'Orazi, G.; Faggioni, A.; Cirone, M. Quercetin induces apoptosis and autophagy in primary effusion lymphoma cells by inhibiting PI3K/AKT/mTOR and STAT3 signaling pathways. J. Nutr. Biochem. 2017, 41, 124-136. [CrossRef] [PubMed]

230. Torossian, A.; Broin, N.; Frentzel, J.; Daugrois, C.; Gandarillas, S.; AlSaati, T.; Lamant, L.; Brousset, P.; Giuriato, S.; Espinos, E. Blockade of crizotinib-induced BCL-2 elevation in ALK-positive ALCL triggers autophagy associated with cell death. Haematologica 2019. [CrossRef] 
231. Brem, E.A.; Thudium, K.; Khubchandani, S.; Tsai, P.C.; Olejniczak, S.H.; Bhat, S.; Riaz, W.; Gu, J.; Iqbal, A.; Campagna, R.; et al. Distinct cellular and therapeutic effects of obatoclax in rituximab-sensitive and -resistant lymphomas. Br. J. Haematol. 2011, 153, 599-611. [CrossRef] [PubMed]

232. Leseux, L.; Laurent, G.; Laurent, C.; Rigo, M.; Blanc, A.; Olive, D.; Bezombes, C. PKC zeta mTOR pathway: A new target for rituximab therapy in follicular lymphoma. Blood 2008, 111, 285-291. [CrossRef] [PubMed]

233. Laane, E.; Tamm, K.P.; Buentke, E.; Ito, K.; Kharaziha, P.; Oscarsson, J.; Corcoran, M.; Björklund, A.-C.; Hultenby, K.; Lundin, J.; et al. Cell death induced by dexamethasone in lymphoid leukemia is mediated through initiation of autophagy. Cell Death Differ. 2009, 16, 1018-1029. [CrossRef] [PubMed]

234. Grander, D.; Kharaziha, P.; Laane, E.; Pokrovskaja, K.; Panaretakis, T. Autophagy as the main means of cytotoxicity by glucocorticoids in hematological malignancies. Autophagy 2009, 5, 1198-1200. [CrossRef]

235. Polak, A.; Kiliszek, P.; Sewastianik, T.; Szydłowski, M.; Jabłońska, E.; Białopiotrowicz, E.; Górniak, P.; Markowicz, S.; Nowak, E.; Grygorowicz, M.A.; et al. MEK Inhibition Sensitizes Precursor B-Cell Acute Lymphoblastic Leukemia (B-ALL) Cells to Dexamethasone through Modulation of mTOR Activity and Stimulation of Autophagy. PLoS ONE 2016, 11, e0155893. [CrossRef]

236. Ristic, B.; Bosnjak, M.; Arsikin, K.; Mircic, A.; Suzin-Zivkovic, V.; Bogdanovic, A.; Perovic, V.; Martinovic, T.; Kravic-Stevovic, T.; Bumbasirevic, V.; et al. Idarubicin induces mTOR-dependent cytotoxic autophagy in leukemic cells. Exp. Cell Res. 2014, 326, 90-102. [CrossRef] [PubMed]

237. Neri, L.M.; Cani, A.; Martelli, A.M.; Simioni, C.; Junghanss, C.; Tabellini, G.; Ricci, F.; Tazzari, P.L.; Pagliaro, P.; McCubrey, J.A.; et al. Targeting the PI3K/Akt/mTOR signaling pathway in B-precursor acute lymphoblastic leukemia and its therapeutic potential. Leukemia 2014, 28, 739-748. [CrossRef] [PubMed]

238. Crazzolara, R.; Bradstock, K.F.; Bendall, L.J. RAD001 (Everolimus) induces autophagy in acute lymphoblastic leukemia. Autophagy 2009, 5, 727-728. [CrossRef]

239. Jia, L.; Dourmashkin, R.R.; Allen, P.D.; Gray, A.B.; Newland, A.C.; Kelsey, S.M. Inhibition of autophagy abrogates tumour necrosis factor alpha induced apoptosis in human T-lymphoblastic leukaemic cells. Br. J. Haematol. 1997, 98, 673-685. [CrossRef] [PubMed]

240. Jiang, Q.; Li, F.; Shi, K.; Wu, P.; An, J.; Yang, Y.; Xu, C. ATF4 activation by the p38MAPK-eIF4E axis mediates apoptosis and autophagy induced by selenite in Jurkat cells. FEBS Lett. 2013, 587, 2420-2429. [CrossRef]

241. Bhadri, V.A.; Trahair, T.N.; Lock, R.B. Glucocorticoid resistance in paediatric acute lymphoblastic leukaemia. J. Paediatr. Child Health 2012, 48, 634-640. [CrossRef] [PubMed]

242. Heidari, N.; Hicks, M.A.; Harada, H. GX15-070 (obatoclax) overcomes glucocorticoid resistance in acute lymphoblastic leukemia through induction of apoptosis and autophagy. Cell Death Dis. 2010, 1, e76. [CrossRef] [PubMed]

243. Urtishak, K.A.; Edwards, A.Y.Z.; Wang, L.-S.; Hudome, A.; Robinson, B.W.; Barrett, J.S.; Cao, K.; Cory, L.; Moore, J.S.; Bantly, A.D.; et al. Potent obatoclax cytotoxicity and activation of triple death mode killing across infant acute lymphoblastic leukemia. Blood 2013, 121, 2689-2703. [CrossRef] [PubMed]

244. Bonapace, L.; Bornhauser, B.C.; Schmitz, M.; Cario, G.; Ziegler, U.; Niggli, F.K.; Schafer, B.W.; Schrappe, M.; Stanulla, M.; Bourquin, J.-P. Induction of autophagy-dependent necroptosis is required for childhood acute lymphoblastic leukemia cells to overcome glucocorticoid resistance. J. Clin. Investig. 2010, 120, 1310-1323. [CrossRef] [PubMed]

245. Sarang, Z.; Gyurina, K.; Scholtz, B.; Kiss, C.; Szegedi, I. Altered expression of autophagy-related genes might contribute to glucocorticoid resistance in precursor B-cell-type acute lymphoblastic leukemia. Eur. J. Haematol. 2016, 97, 453-460. [CrossRef] [PubMed]

246. Wallington-Beddoe, C.T.; Hewson, J.; Bradstock, K.F.; Bendall, L.J. FTY720 produces caspase-independent cell death of acute lymphoblastic leukemia cells. Autophagy 2011, 7, 707-715. [CrossRef] [PubMed]

247. Evangelisti, C.; Ricci, F.; Tazzari, P.; Chiarini, F.; Battistelli, M.; Falcieri, E.; Ognibene, A.; Pagliaro, P.; Cocco, L.; McCubrey, J.A.; et al. Preclinical testing of the Akt inhibitor triciribine in T-cell acute lymphoblastic leukemia. J. Cell. Physiol. 2011, 226, 822-831. [CrossRef]

248. Herranz, D.; Ambesi-Impiombato, A.; Sudderth, J.; Sanchez-Martin, M.; Belver, L.; Tosello, V.; Xu, L.; Wendorff, A.A.; Castillo, M.; Haydu, J.E.; et al. Metabolic reprogramming induces resistance to anti-NOTCH1 therapies in T cell acute lymphoblastic leukemia. Nat. Med. 2015, 21, 1182-1189. [CrossRef]

249. Hongo, T.; Yajima, S.; Sakurai, M.; Horikoshi, Y.; Hanada, R. In vitro drug sensitivity testing can predict induction failure and early relapse of childhood acute lymphoblastic leukemia. Blood 1997, 89, 2959-2965. 
250. Kaspers, G.J.; Veerman, A.J.; Pieters, R.; Van Zantwijk, C.H.; Smets, L.A.; Van Wering, E.R.; Van Der Does-Van Den Berg, A. In vitro cellular drug resistance and prognosis in newly diagnosed childhood acute lymphoblastic leukemia. Blood 1997, 90, 2723-2729.

251. Takahashi, H.; Inoue, J.; Sakaguchi, K.; Takagi, M.; Mizutani, S.; Inazawa, J. Autophagy is required for cell survival under L-asparaginase-induced metabolic stress in acute lymphoblastic leukemia cells. Oncogene 2017, 36, 4267-4276. [CrossRef] [PubMed]

252. Bennett, J.M.; Catovsky, D.; Daniel, M.T.; Flandrin, G.; Galton, D.A.G.; Gralnick, H.R.; Sultan, C. Proposals for the classification of the myelodysplastic syndromes. Br. J. Haematol. 1982, 51, 189-199. [CrossRef] [PubMed]

253. Li, J. Myelodysplastic syndrome hematopoietic stem cell. Int. J. Cancer 2013, 133, 525-533. [CrossRef] [PubMed]

254. Woll, P.S.; Kjällquist, U.; Chowdhury, O.; Doolittle, H.; Wedge, D.C.; Thongjuea, S.; Erlandsson, R.; Ngara, M.; Anderson, K.; Deng, Q.; et al. Myelodysplastic syndromes are propagated by rare and distinct human cancer stem cells in vivo. Cancer Cell 2014, 25, 794-808. [CrossRef] [PubMed]

255. Papaemmanuil, E.; Gerstung, M.; Malcovati, L.; Tauro, S.; Gundem, G.; Van Loo, P.; Yoon, C.J.; Ellis, P.; Wedge, D.C.; Pellagatti, A.; et al. Clinical and biological implications of driver mutations in myelodysplastic syndromes. Blood 2013, 122, 3616-3627; quiz 3699. [CrossRef] [PubMed]

256. Parmar, S.; de Lima, M.; Deeg, H.J.; Champlin, R. Hematopoietic stem cell transplantation for myelodysplastic syndrome: A review. Semin. Oncol. 2011, 38, 693-704. [CrossRef] [PubMed]

257. Odenike, O.; Onida, F.; Padron, E. Myelodysplastic syndromes and myelodysplastic/myeloproliferative neoplasms: An update on risk stratification, molecular genetics, and therapeutic approaches including allogeneic hematopoietic stem cell transplantation. Am. Soc. Clin. Oncol. Educ. Book 2015, e398-e412. [CrossRef]

258. Saliba, J.; Saint-Martin, C.; Di Stefano, A.; Lenglet, G.; Marty, C.; Keren, B.; Pasquier, F.; Valle, V.D.; Secardin, L.; Leroy, G.; et al. Germline duplication of ATG2B and GSKIP predisposes to familial myeloid malignancies. Nat. Genet. 2015, 47, 1131-1140. [CrossRef]

259. Park, S.M.; Ou, J.; Chamberlain, L.; Simone, T.M.; Yang, H.; Virbasius, C.-M.; Ali, A.M.; Zhu, L.J.; Mukherjee, S.; Raza, A.; et al. U2AF35(S34F) Promotes Transformation by Directing Aberrant ATG7 Pre-mRNA 3' End Formation. Mol. Cell 2016, 62, 479-490. [CrossRef]

260. Jiang, H.; Yang, L.; Guo, L.; Cui, N.; Zhang, G.; Liu, C.; Xing, L.; Shao, Z.; Wang, H. Impaired Mitophagy of Nucleated Erythroid Cells Leads to Anemia in Patients with Myelodysplastic Syndromes. Oxid. Med. Cell. Longev. 2018, 2018, 6328051. [CrossRef]

261. Zhuang, L.; Ma, Y.; Wang, Q.; Zhang, J.; Zhu, C.; Zhang, L.; Xu, X. Atg3 Overexpression Enhances Bortezomib-Induced Cell Death in SKM-1 Cell. PLoS ONE 2016, 11, e0158761. [CrossRef] [PubMed]

262. Ossenkoppele, G.; Löwenberg, B. How I treat the older patient with acute myeloid leukemia. Blood 2015, 125, 767-774. [CrossRef] [PubMed]

263. Arber, D.A.; Orazi, A.; Hasserjian, R.; Thiele, J.; Borowitz, M.J.; Beau, M.M.L.; Bloomfield, C.D.; Cazzola, M.; Vardiman, J.W. The 2016 revision to the World Health Organization classification of myeloid neoplasms and acute leukemia. Blood 2016, 127, 2391-2405. [CrossRef] [PubMed]

264. Schnegg-Kaufmann, A.; Feller, A.; Baldomero, H.; Rovo, A.; Manz, M.G.; Gregor, M.; Efthymiou, A.; Bargetzi, M.; Hess, U.; Spertini, O.; et al. Improvement of relative survival in elderly patients with acute myeloid leukaemia emerging from population-based cancer registries in Switzerland between 2001 and 2013. Cancer Epidemiol. 2018, 52, 55-62. [CrossRef] [PubMed]

265. Juliusson, G.; Lazarevic, V.; Hörstedt, A.-S.; Hagberg, O.; Höglund, M.; Swedish Acute Leukemia Registry Group. Acute myeloid leukemia in the real world: Why population-based registries are needed. Blood 2012, 119, 3890-3899. [CrossRef] [PubMed]

266. Jin, J.; Britschgi, A.; Schläfli, A.M.; Humbert, M.; Shan-Krauer, D.; Batliner, J.; Federzoni, E.A.; Ernst, M.; Torbett, B.E.; Yousefi, S.; et al. Low Autophagy (ATG) Gene Expression Is Associated with an Immature AML Blast Cell Phenotype and Can Be Restored during AML Differentiation Therapy. Oxid. Med. Cell. Longev. 2018, 2018, 1482795. [CrossRef] [PubMed]

267. Watson, A.S.; Riffelmacher, T.; Stranks, A.; Williams, O.; De Boer, J.; Cain, K.; MacFarlane, M.; McGouran, J.; Kessler, B.; Khandwala, S.; et al. Autophagy limits proliferation and glycolytic metabolism in acute myeloid leukemia. Cell Death Discov. 2015, 1, 15008. [CrossRef] 
268. Meenhuis, A.; van Veelen, P.A.; de Looper, H.; van Boxtel, N.; van den Berge, I.J.; Sun, S.M.; Taskesen, E.; Stern, P.; de Ru, A.H.; van Adrichem, A.J.; et al. MiR-17/20/93/106 promote hematopoietic cell expansion by targeting sequestosome 1-regulated pathways in mice. Blood 2011, 118, 916-925. [CrossRef]

269. Trocoli, A.; Bensadoun, P.; Richard, E.; Labrunie, G.; Merhi, F.; Schläfli, A.M.; Brigger, D.; Souquere, S.; Pierron, G.; Pasquet, J.-M.; et al. p62/SQSTM1 upregulation constitutes a survival mechanism that occurs during granulocytic differentiation of acute myeloid leukemia cells. Cell Death Differ. 2014, 21, 1852. [CrossRef]

270. Ségal-Bendirdjian, E.; Tschan, M.P.; Reiffers, J.; Djavaheri-Mergny, M. Pro-survival role of p62 during granulocytic differentiation of acute myeloid leukemia cells. Mol. Cell. Oncol. 2014, 1, e970066. [CrossRef]

271. Nguyen, T.D.; Shaid, S.; Vakhrusheva, O.; Koschade, S.E.; Klann, K.; Thölken, M.; Baker, F.; Zhang, J.; Oellerich, T.; Sürün, D.; et al. Loss of the selective autophagy receptor p62 impairs murine myeloid leukemia progression and mitophagy. Blood 2019, 133, 168-179. [CrossRef] [PubMed]

272. Rudat, S.; Pfaus, A.; Cheng, Y.Y.; Holtmann, J.; Ellegast, J.M.; Bühler, C.; Marcantonio, D.D.; Martinez, E.; Göllner, S.; Wickenhauser, C.; et al. RET-mediated autophagy suppression as targetable co-dependence in acute myeloid leukemia. Leukemia 2018, 32, 2189-2202. [CrossRef] [PubMed]

273. Larrue, C.; Saland, E.; Boutzen, H.; Vergez, F.; David, M.; Joffre, C.; Hospital, M.-A.; Tamburini, J.; Delabesse, E.; Manenti, S.; et al. Proteasome inhibitors induce FLT3-ITD degradation through autophagy in AML cells. Blood 2016, 127, 882-892. [CrossRef] [PubMed]

274. Heydt, Q.; Larrue, C.; Saland, E.; Bertoli, S.; Sarry, J.-E.; Besson, A.; Manenti, S.; Joffre, C.; Mansat-De Mas, V. Oncogenic FLT3-ITD supports autophagy via ATF4 in acute myeloid leukemia. Oncogene 2018, 37, 787-797. [CrossRef] [PubMed]

275. Zou, Q.; Tan, S.; Yang, Z.; Zhan, Q.; Jin, H.; Xian, J.; Zhang, S.; Yang, L.; Wang, L.; Zhang, L. NPM1 Mutant Mediated PML Delocalization and Stabilization Enhances Autophagy and Cell Survival in Leukemic Cells. Theranostics 2017, 7, 2289-2304. [CrossRef] [PubMed]

276. Sumitomo, Y.; Koya, J.; Nakazaki, K.; Kataoka, K.; Tsuruta-Kishino, T.; Morita, K.; Sato, T.; Kurokawa, M. Cytoprotective autophagy maintains leukemia-initiating cells in murine myeloid leukemia. Blood 2016, 128, 1614-1624. [CrossRef] [PubMed]

277. Man, N.; Tan, Y.; Sun, X.-J.; Liu, F.; Cheng, G.; Greenblatt, S.M.; Martinez, C.; Karl, D.L.; Ando, K.; Sun, M.; et al. Caspase-3 controls AML1-ETO-driven leukemogenesis via autophagy modulation in a ULK1-dependent manner. Blood 2017, 129, 2782-2792. [CrossRef] [PubMed]

278. Chen, X.; Clark, J.; Wunderlich, M.; Fan, C.; Davis, A.; Chen, S.; Guan, J.-L.; Mulloy, J.C.; Kumar, A.; Zheng, Y. Autophagy is dispensable for Kmt2a/Mll-Mllt3/Af9 AML maintenance and anti-leukemic effect of chloroquine. Autophagy 2017, 13, 955-966. [CrossRef] [PubMed]

279. Liu, Q.; Chen, L.; Atkinson, J.M.; Claxton, D.F.; Wang, H.-G. Atg5-dependent autophagy contributes to the development of acute myeloid leukemia in an MLL-AF9-driven mouse model. Cell Death Dis. 2016, 7, e2361. [CrossRef] [PubMed]

280. Piragyte, I.; Clapes, T.; Polyzou, A.; Klein Geltink, R.I.; Lefkopoulos, S.; Yin, N.; Cauchy, P.; Curtis, J.D.; Klaeylé, L.; Langa, X.; et al. A metabolic interplay coordinated by HLX regulates myeloid differentiation and AML through partly overlapping pathways. Nat. Commun. 2018, 9, 3090. [CrossRef] [PubMed]

281. Helgason, G.V.; Mukhopadhyay, A.; Karvela, M.; Salomoni, P.; Calabretta, B.; Holyoake, T.L. Autophagy in chronic myeloid leukaemia: Stem cell survival and implication in therapy. Curr. Cancer Drug Targets 2013, 13, 724-734. [CrossRef] [PubMed]

282. Goussetis, D.J.; Gounaris, E.; Wu, E.J.; Vakana, E.; Sharma, B.; Bogyo, M.; Altman, J.K.; Platanias, L.C. Autophagic degradation of the BCR-ABL oncoprotein and generation of antileukemic responses by arsenic trioxide. Blood 2012, 120, 3555-3562. [CrossRef] [PubMed]

283. Colecchia, D.; Rossi, M.; Sasdelli, F.; Sanzone, S.; Strambi, A.; Chiariello, M. MAPK15 mediates BCR-ABL1-induced autophagy and regulates oncogene-dependent cell proliferation and tumor formation. Autophagy 2015, 11, 1790-1802. [CrossRef] [PubMed]

284. Sheng, Z.; Ma, L.; Sun, J.E.; Zhu, L.J.; Green, M.R. BCR-ABL suppresses autophagy through ATF5-mediated regulation of mTOR transcription. Blood 2011, 118, 2840-2848. [CrossRef] [PubMed]

285. Baquero, P.; Dawson, A.; Mukhopadhyay, A.; Kuntz, E.M.; Mitchell, R.; Olivares, O.; Ianniciello, A.; Scott, M.T.; Dunn, K.; Nicastri, M.C.; et al. Targeting quiescent leukemic stem cells using second generation autophagy inhibitors. Leukemia 2018. [CrossRef] [PubMed] 
286. Ianniciello, A.; Dumas, P.-Y.; Drullion, C.; Guitart, A.; Villacreces, A.; Peytour, Y.; Chevaleyre, J.; Brunet de la Grange, P.; Vigon, I.; Desplat, V.; et al. Chronic myeloid leukemia progenitor cells require autophagy when leaving hypoxia-induced quiescence. Oncotarget 2017, 8, 96984-96992. [CrossRef]

287. Mourgues, L.; Imbert, V.; Nebout, M.; Colosetti, P.; Neffati, Z.; Lagadec, P.; Verhoeyen, E.; Peng, C.; Duprez, E.; Legros, L.; et al. The BMI1 polycomb protein represses cyclin G2-induced autophagy to support proliferation in chronic myeloid leukemia cells. Leukemia 2015, 29, 1993-2002. [CrossRef]

288. Cluzeau, T.; Robert, G.; Jacquel, A.; Auberger, P. How recent advances in high-risk myelodysplastic syndrome physiopathology may impact future treatments. Curr. Pharm. Des. 2013, 19, 5362-5373. [CrossRef]

289. Zeng, W.; Dai, H.; Yan, M.; Cai, X.; Luo, H.; Ke, M.; Liu, Z. Decitabine-Induced Changes in Human Myelodysplastic Syndrome Cell Line SKM-1 Are Mediated by FOXO3A Activation. J. Immunol. Res. 2017, 2017, 4302320. [CrossRef]

290. Dubois, A.; Furstoss, N.; Calleja, A.; Zerhouni, M.; Cluzeau, T.; Savy, C.; Marchetti, S.; Hamouda, M.A.; Boulakirba, S.; Orange, F.; et al. LAMP2 expression dictates azacytidine response and prognosis in MDS/AML. Leukemia 2019. [CrossRef]

291. Fabre, C.; Carvalho, G.; Tasdemir, E.; Braun, T.; Adès, L.; Grosjean, J.; Boehrer, S.; Métivier, D.; Souquère, S.; Pierron, G.; et al. NF-кB inhibition sensitizes to starvation-induced cell death in high-risk myelodysplastic syndrome and acute myeloid leukemia. Oncogene 2007, 26, 4071-4083. [CrossRef] [PubMed]

292. Fang, J.; Rhyasen, G.; Bolanos, L.; Rasch, C.; Varney, M.; Wunderlich, M.; Goyama, S.; Jansen, G.; Cloos, J.; Rigolino, C.; et al. Cytotoxic effects of bortezomib in myelodysplastic syndrome/acute myeloid leukemia depend on autophagy-mediated lysosomal degradation of TRAF6 and repression of PSMA1. Blood 2012, 120, 858-867. [CrossRef] [PubMed]

293. Evangelisti, C.; Evangelisti, C.; Chiarini, F.; Lonetti, A.; Buontempo, F.; Neri, L.M.; McCubrey, J.A.; Martelli, A.M. Autophagy in acute leukemias: A double-edged sword with important therapeutic implications. Biochim. Biophys. Acta 2015, 1853, 14-26. [CrossRef] [PubMed]

294. Willems, L.; Chapuis, N.; Puissant, A.; Maciel, T.T.; Green, A.S.; Jacque, N.; Vignon, C.; Park, S.; Guichard, S.; Herault, O; et al. The dual mTORC1 and mTORC2 inhibitor AZD8055 has anti-tumor activity in acute myeloid leukemia. Leukemia 2012, 26, 1195-1202. [CrossRef] [PubMed]

295. Liu, L.; Yang, M.; Kang, R.; Wang, Z.; Zhao, Y.; Yu, Y.; Xie, M.; Yin, X.; Livesey, K.M.; Lotze, M.T.; et al. HMGB1-induced autophagy promotes chemotherapy resistance in leukemia cells. Leukemia 2011, 25, $23-31$. [CrossRef] [PubMed]

296. Cheong, J.-W.; Kim, Y.; Eom, J.I.; Jeung, H.-K.; Min, Y.H. Enhanced autophagy in cytarabine arabinoside-resistant U937 leukemia cells and its potential as a target for overcoming resistance. Mol. Med. Rep. 2016, 13, 3433-3440. [CrossRef] [PubMed]

297. Piya, S.; Kornblau, S.M.; Ruvolo, V.R.; Mu, H.; Ruvolo, P.P.; McQueen, T.; Davis, R.E.; Hail, N.J.; Kantarjian, H.; Andreeff, M.; et al. Atg7 suppression enhances chemotherapeutic agent sensitivity and overcomes stroma-mediated chemoresistance in acute myeloid leukemia. Blood 2016, 128, 1260-1269. [CrossRef]

298. Chen, L.; Guo, P.; Jia, P.; Tong, J.; Hu, J.; Li, J. Autophagy Is an Important Event for Low Dose Cytarabine Treatment in Acute Myeloid Leukemia U937 Cell Line. Blood 2014, 124, 5209.

299. Altman, J.K.; Szilard, A.; Goussetis, D.J.; Sassano, A.; Colamonici, M.; Gounaris, E.; Frankfurt, O.; Giles, F.J.; Eklund, E.A.; Beauchamp, E.M.; et al. Autophagy is a survival mechanism of acute myelogenous leukemia precursors during dual mTORC2/mTORC1 targeting. Clin. Cancer Res. 2014, 20, 2400-2409. [CrossRef]

300. Willems, L.; Jacque, N.; Jacquel, A.; Neveux, N.; Maciel, T.T.; Lambert, M.; Schmitt, A.; Poulain, L.; Green, A.S.; Uzunov, M.; et al. Inhibiting glutamine uptake represents an attractive new strategy for treating acute myeloid leukemia. Blood 2013, 122, 3521-3532. [CrossRef]

301. Torgersen, M.L.; Engedal, N.; Bøe, S.-O.; Hokland, P.; Simonsen, A. Targeting autophagy potentiates the apoptotic effect of histone deacetylase inhibitors in t(8;21) AML cells. Blood 2013, 122, 2467-2476. [CrossRef] [PubMed]

302. Stankov, M.V.; El Khatib, M.; Kumar Thakur, B.; Heitmann, K.; Panayotova-Dimitrova, D.; Schoening, J.; Bourquin, J.P.; Schweitzer, N.; Leverkus, M.; Welte, K.; et al. Histone deacetylase inhibitors induce apoptosis in myeloid leukemia by suppressing autophagy. Leukemia 2014, 28, 577-588. [CrossRef] [PubMed]

303. Rahmani, M.; Aust, M.M.; Attkisson, E.; Williams, D.C.; Ferreira-Gonzalez, A.; Grant, S. Inhibition of Bcl-2 antiapoptotic members by obatoclax potently enhances sorafenib-induced apoptosis in human myeloid leukemia cells through a Bim-dependent process. Blood 2012, 119, 6089-6098. [CrossRef] [PubMed] 
304. Takeuchi, R.; Hoshijima, H.; Nagasaka, H.; Chowdhury, S.A.; Kikuchi, H.; Kanda, Y.; Kunii, S.; Kawase, M.; Sakagami, H. Induction of non-apoptotic cell death by morphinone in human promyelocytic leukemia HL-60 cells. Anti-Cancer Res. 2006, 26, 3343-3348.

305. Sujobert, P.; Poulain, L.; Paubelle, E.; Zylbersztejn, F.; Grenier, A.; Lambert, M.; Townsend, E.C.; Brusq, J.M.; Nicodeme, E.; Decrooqc, J.; et al. Co-activation of AMPK and mTORC1 Induces Cytotoxicity in Acute Myeloid Leukemia. Cell Rep. 2015, 11, 1446-1457. [CrossRef] [PubMed]

306. Goussetis, D.J.; Altman, J.K.; Glaser, H.; McNeer, J.L.; Tallman, M.S.; Platanias, L.C. Autophagy is a critical mechanism for the induction of the antileukemic effects of arsenic trioxide. J. Biol. Chem. 2010, 285, 29989-29997. [CrossRef]

307. Isakson, P.; Bjørås, M.; Bøe, S.O.; Simonsen, A. Autophagy contributes to therapy-induced degradation of the PML/RARA oncoprotein. Blood 2010, 116, 2324-2331. [CrossRef]

308. Sanz, M.A.; Grimwade, D.; Tallman, M.S.; Lowenberg, B.; Fenaux, P.; Estey, E.H.; Naoe, T.; Lengfelder, E.; Buchner, T.; Dohner, H.; et al. Management of acute promyelocytic leukemia: Recommendations from an expert panel on behalf of the European LeukemiaNet. Blood 2009, 113, 1875-1891. [CrossRef]

309. Wang, Z.; Cao, L.; Kang, R.; Yang, M.; Liu, L.; Zhao, Y.; Yu, Y.; Xie, M.; Yin, X.; Livesey, K.M.; et al. Autophagy regulates myeloid cell differentiation by p62/SQSTM1-mediated degradation of PML-RARalpha oncoprotein. Autophagy 2011, 7, 401-411. [CrossRef]

310. Trocoli, A.; Mathieu, J.; Priault, M.; Reiffers, J.; Souquere, S.; Pierron, G.; Besançon, F.; Djavaheri-Mergny, M. ATRA-induced upregulation of Beclin 1 prolongs the life span of differentiated acute promyelocytic leukemia cells. Autophagy 2011, 7, 1108-1114. [CrossRef]

311. Huang, Y.; Hou, J.-K.; Chen, T.-T.; Zhao, X.-Y.; Yan, Z.-W.; Zhang, J.; Yang, J.; Kogan, S.C.; Chen, G.-Q. PML-RARalpha enhances constitutive autophagic activity through inhibiting the Akt/mTOR pathway. Autophagy 2011, 7, 1132-1144. [CrossRef] [PubMed]

312. Brigger, D.; Proikas-Cezanne, T.; Tschan, M.P. WIPI-dependent autophagy during neutrophil differentiation of NB4 acute promyelocytic leukemia cells. Cell Death Dis. 2014, 5, e1315. [CrossRef]

313. Brigger, D.; Torbett, B.E.; Chen, J.; Fey, M.F.; Tschan, M.P. Inhibition of GATE-16 attenuates ATRA-induced neutrophil differentiation of APL cells and interferes with autophagosome formation. Biochem. Biophys. Res. Commun. 2013, 438, 283-288. [CrossRef] [PubMed]

314. Humbert, M.; Mueller, C.; Fey, M.F.; Tschan, M.P. Inhibition of damage-regulated autophagy modulator-1 (DRAM-1) impairs neutrophil differentiation of NB4 APL cells. Leuk. Res. 2012, 36, 1552-1556. [CrossRef] [PubMed]

315. Haimovici, A.; Brigger, D.; Torbett, B.E.; Fey, M.F.; Tschan, M.P. Induction of the autophagy-associated gene MAP1S via PU.1 supports APL differentiation. Leuk. Res. 2014, 38, 1041-1047. [CrossRef] [PubMed]

316. Liu, L.; Ren, W.; Chen, K. MiR-34a Promotes Apoptosis and Inhibits Autophagy by Targeting HMGB1 in Acute Myeloid Leukemia Cells. Cell. Physiol. Biochem. 2017, 41, 1981-1992. [CrossRef]

317. Zeng, C.W.; Chen, Z.H.; Zhang, X.J.; Han, B.W.; Lin, K.Y.; Li, X.J.; Wei, P.P.; Zhang, H.; Li, Y.; Chen, Y.Q. MIR125B1 represses the degradation of the PML-RARA oncoprotein by an autophagylysosomal pathway in acute promyelocytic leukemia. Autophagy 2014, 10, 1726-1737. [CrossRef]

318. Chen, Z.-H.; Wang, W.-T.; Huang, W.; Fang, K.; Sun, Y.-M.; Liu, S.-R.; Luo, X.-Q.; Chen, Y.-Q. The lncRNA HOTAIRM1 regulates the degradation of PML-RARA oncoprotein and myeloid cell differentiation by enhancing the autophagy pathway. Cell Death Differ. 2017, 24, 212-224. [CrossRef]

319. Ganesan, S.; Alex, A.A.; Chendamarai, E.; Balasundaram, N.; Palani, H.K.; David, S.; Kulkarni, U.; Aiyaz, M.; Mugasimangalam, R.; Korula, A.; et al. Rationale and efficacy of proteasome inhibitor combined with arsenic trioxide in the treatment of acute promyelocytic leukemia. Leukemia 2016, 30, 2169-2178. [CrossRef]

320. Xie, N.; Zhong, L.; Liu, L.; Fang, Y.; Qi, X.; Cao, J.; Yang, B.; He, Q.; Ying, M. Autophagy contributes to dasatinib-induced myeloid differentiation of human acute myeloid leukemia cells. Biochem. Pharmacol. 2014, 89, 74-85. [CrossRef]

321. Lau, A.; Zheng, Y.; Tao, S.; Wang, H.; Whitman, S.A.; White, E.; Zhang, D.D. Arsenic inhibits autophagic flux, activating the Nrf2-Keap1 pathway in a p62-dependent manner. Mol. Cell. Biol. 2013, 33, 2436-2446. [CrossRef] [PubMed]

322. Elzinga, B.M.; Nyhan, M.J.; Crowley, L.C.; O’Donovan, T.R.; Cahill, M.R.; McKenna, S.L. Induction of autophagy by Imatinib sequesters $\mathrm{Bcr}-\mathrm{Abl}$ in autophagosomes and down-regulates Bcr-Abl protein. Am. J. Hematol. 2013, 88, 455-462. [CrossRef] [PubMed] 
323. Carew, J.S.; Nawrocki, S.T.; Kahue, C.N.; Zhang, H.; Yang, C.; Chung, L.; Houghton, J.A.; Huang, P.; Giles, F.J.; Cleveland, J.L. Targeting autophagy augments the anticancer activity of the histone deacetylase inhibitor SAHA to overcome Bcr-Abl-mediated drug resistance. Blood 2007, 110, 313-322. [CrossRef] [PubMed]

324. Bellodi, C.; Lidonnici, M.R.; Hamilton, A.; Helgason, G.V.; Soliera, A.R.; Ronchetti, M.; Galavotti, S.; Young, K.W.; Selmi, T.; Yacobi, R.; et al. Targeting autophagy potentiates tyrosine kinase inhibitor-induced cell death in Philadelphia chromosome-positive cells, including primary CML stem cells. J. Clin. Investig. 2009, 119, 1109-1123. [CrossRef] [PubMed]

325. Helgason, G.V.; Karvela, M.; Holyoake, T.L. Kill one bird with two stones: Potential efficacy of BCR-ABL and autophagy inhibition in CML. Blood 2011, 118, 2035-2043. [CrossRef] [PubMed]

326. Calabretta, B.; Salomoni, P. Inhibition of autophagy: A new strategy to enhance sensitivity of chronic myeloid leukemia stem cells to tyrosine kinase inhibitors. Leuk. Lymphoma 2011, 52 (Suppl. 1), 54-59. [CrossRef]

327. Crowley, L.C.; O’Donovan, T.R.; Nyhan, M.J.; McKenna, S.L. Pharmacological agents with inherent anti-autophagic activity improve the cytotoxicity of imatinib. Oncol. Rep. 2013, 29, 2261-2268. [CrossRef] [PubMed]

328. Zeng, X.; Zhao, H.; Li, Y.; Fan, J.; Sun, Y.; Wang, S.; Wang, Z.; Song, P.; Ju, D. Targeting Hedgehog signaling pathway and autophagy overcomes drug resistance of BCR-ABLpositive chronic myeloid leukemia. Autophagy 2015, 11, 355-372. [CrossRef]

329. Puissant, A.; Auberger, P. AMPK- and p62/SQSTM1-dependent autophagy mediate resveratrol-induced cell death in chronic myelogenous leukemia. Autophagy 2010, 6, 655-657. [CrossRef]

330. Puissant, A.; Robert, G.; Fenouille, N.; Luciano, F.; Cassuto, J.P.; Raynaud, S.; Auberger, P. Resveratrol promotes autophagic cell death in chronic myelogenous leukemia cells via JNK-mediated p62/SQSTM1 expression and AMPK activation. Cancer Res. 2010, 70, 1042-1052. [CrossRef]

331. Robert, G.; Ben Sahra, I.; Puissant, A.; Colosetti, P.; Belhacene, N.; Gounon, P.; Hofman, P.; Bost, F.; Cassuto, J.P.; Auberger, P. Acadesine kills Chronic Myelogenous Leukemia (CML) cells through PKC-dependent induction of autophagic cell death. PLoS ONE 2009, 4, e7889. [CrossRef] [PubMed]

332. Tong, Y.; You, L.; Liu, H.; Li, L.; Meng, H.; Qian, Q.; Qian, W. Potent antitumor activity of oncolytic adenovirus expressing Beclin-1 via induction of autophagic cell death in leukemia. Oncotarget 2013, 4, 860-874. [CrossRef] [PubMed]

333. Thorburn, A. Autophagy and Disease. J. Biol. Chem. 2017. [CrossRef] [PubMed]

334. Mauthe, M.; Orhon, I.; Rocchi, C.; Zhou, X.; Luhr, M.; Hijlkema, K.-J.; Coppes, R.P.; Engedal, N.; Mari, M.; Reggiori, F. Chloroquine inhibits autophagic flux by decreasing autophagosome-lysosome fusion. Autophagy 2018, 14, 1435-1455. [CrossRef] [PubMed]

(C) 2019 by the authors. Licensee MDPI, Basel, Switzerland. This article is an open access article distributed under the terms and conditions of the Creative Commons Attribution (CC BY) license (http://creativecommons.org/licenses/by/4.0/). 